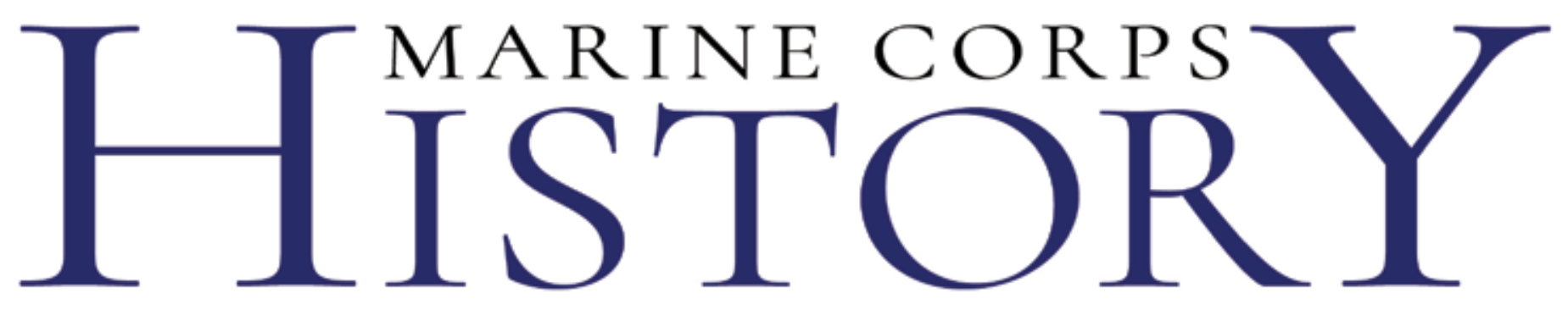

VOLUME 5, NUMBER 2

WINTER 2019

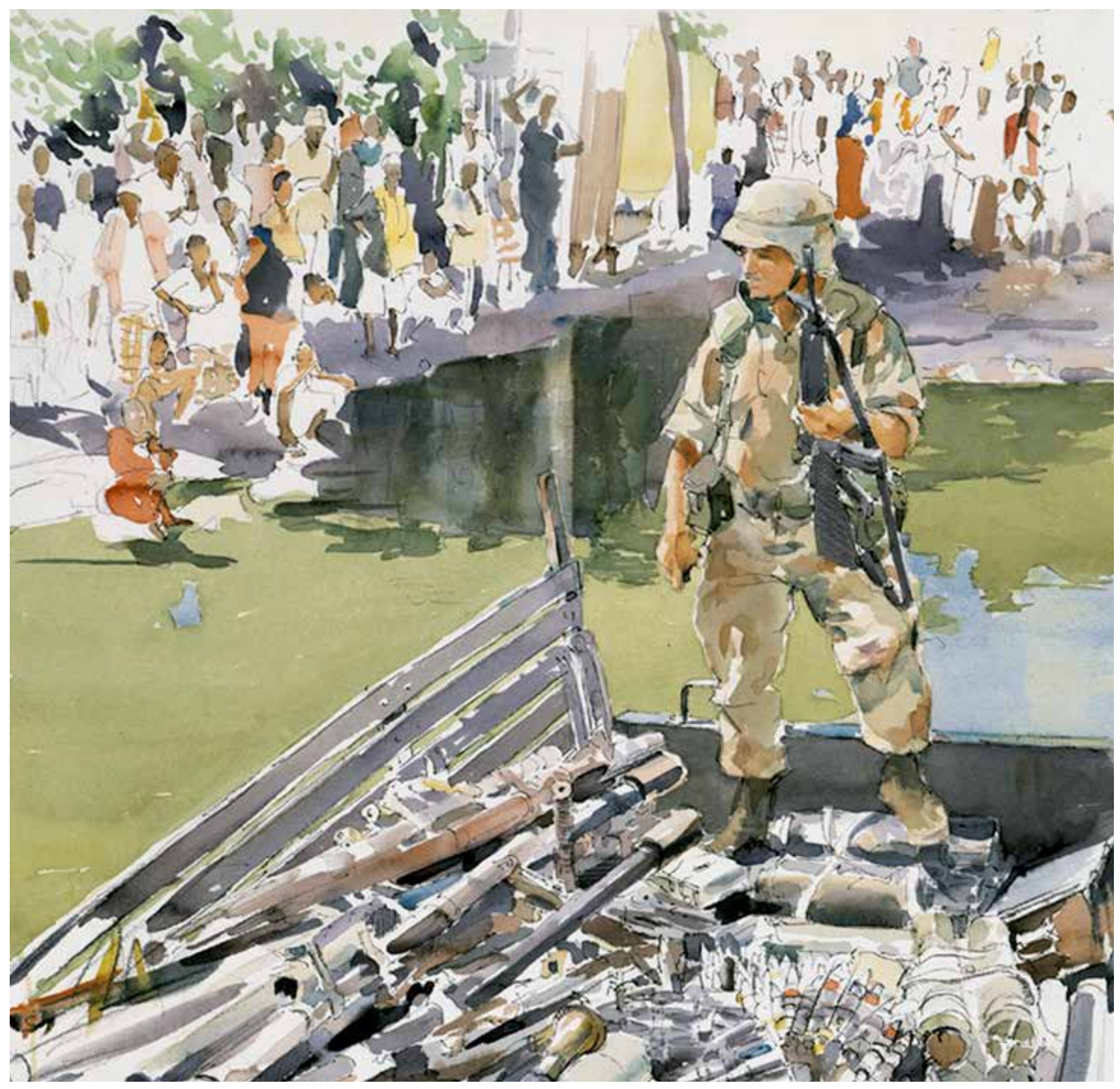




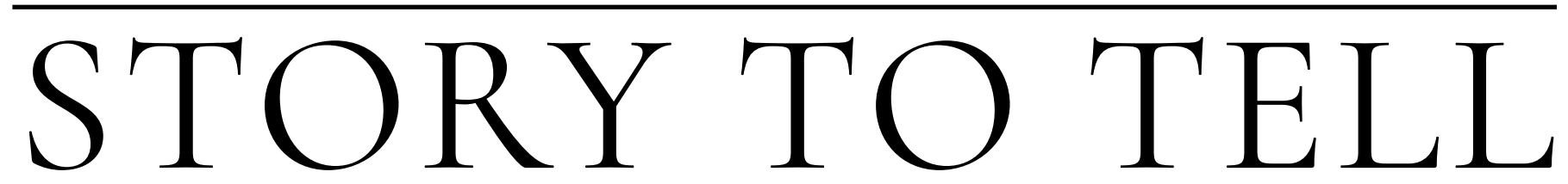

Marine Corps History is accepting article and book review submissions for $2020-21$.

MCU Press publishes Marine Corps History twice a year, and the editors are currently looking for new articles and book reviews on all topics within the long history of the Corps: Civil War, Spanish-American War, Banana Wars, WWI, WWII, Korea, Cold War, Vietnam, Iraq, Afghanistan, and women and minorities in the military. We are particularly interested in masters and $\mathrm{PhD}$ students who are ready to venture into scholarly publishing. Articles must be at least 4,00o words, footnoted according to Chicago Manual of Style, and focus on some aspect of the Corps either directly or indirectly, including foreign marines and joint operations.

For more information about submission guidelines or history books available for review, please contact the managing editor at stephani.miller@usmcu.edu.

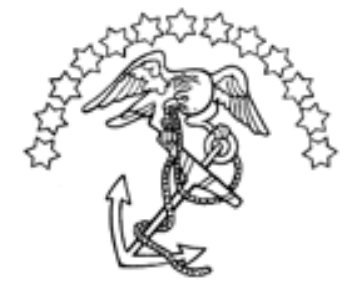

\section{NEW FROM MCUP}
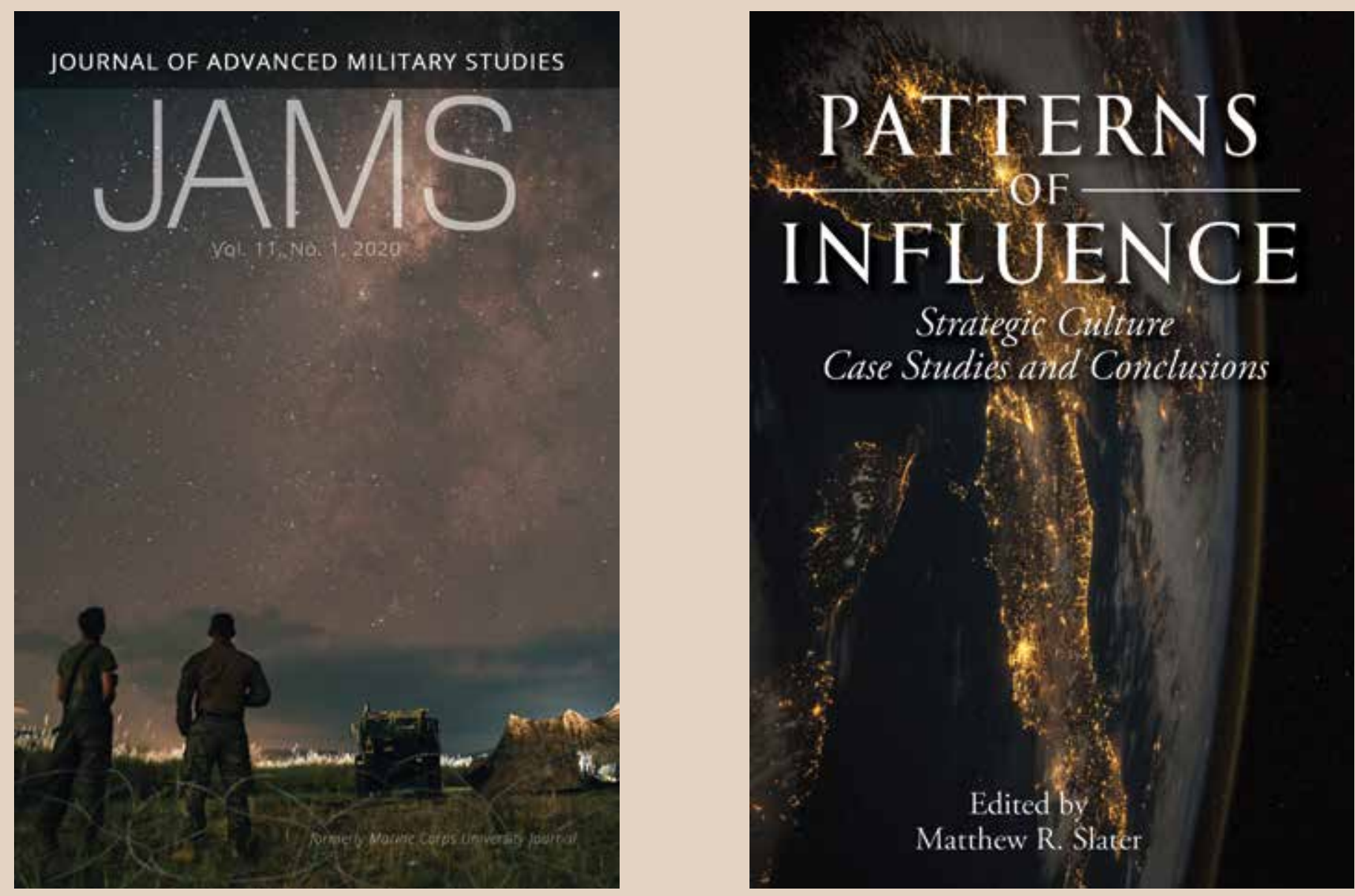


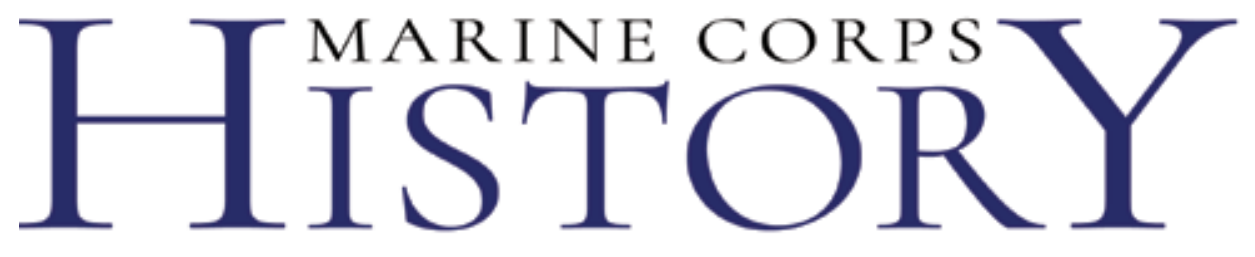

Volume 5, Number 2

PRESIDENT

Marine Corps University

Brigadier General Jay M. Bargeron

\section{DIRECTOR}

History Division

Dr. Edward T. Nevgloski

\section{DEPUTY DIRECTOR}

Paul J. Weber

\section{EXECUTIVE ASSISANT \\ Cassandra Bennett}

\section{SPECIAL PROJECTS}

Annette D. Amerman

\section{HISTORIES BRANCH}

Dr. Frank Kalesnik (Chief Historian),

Dr. Seth Givens (acting Branch Head),

Paul W. Westermeyer, Dr. Breanne

Robertson, Kara R. Newcomer, Mike

Westermeier, Dr. Jordan Malfoy

\section{HISTORICAL RESOURCES BRANCH}

Alisa Whitley (Branch Head)

Steve Coode, John Lyles, Nancy Whitfield,

Alyson Mazzone, Dominic Amaral

\section{MCU PRESS}

Angela J. Anderson (Director)

Jason Gosnell, Robert A. Kocher,

Stephani L. Miller, Christopher N. Blaker,

Jeffrey Moravetz, Jose Esquilin

\section{MARINE CORPS}

HISTORY DIVISION

2044 Broadway Street

Quantico, Virginia 22134

Telephone (703) 432-4877

www.usmcu.edu/HDPublishing

\section{$\circ \circ \circ$}

COMMANDANT OF THE MARINE CORPS

Department of the Navy

Headquarters Marine Corps

3000 Marine Corps Pentagon

Room 2B253

Washington, DC 20530-3000

OFFICIAL BUSINESS

PCN 10600011300

ISSN 2381-375X

The production of this journal and other MCUP products graciously supported by the Marine Corps Heritage Foundation.

Cover art: Arms Seized at Bakara Market, by Col Peter Gish, USMCR (Ret). Combat Art Collection, National Museum of the Marine Corps
Director's Foreword

Edward T. Nevgloski, PhD

\section{ARTICLES}

General Pershing and the U.S. Marines

Colonel Peter T. Underwood, USMC (Ret)

Stability or Disruption: The U.S. Marine Occupation

and the Voodoo Trials in Haiti, 1926-30

David J. Ulbrich, PhD

The Birth and Early Years of Marine Corps Intelligence

Michael H. Decker and William Mackenzie

"Tree Hugging Work": The Shifting Attitudes and Practices

of the U.S. Marine Corps Toward Peace Operations in the $1990 \mathrm{os}$

Mary Elizabeth Walters, PhD

The Triptych of Modern Combat: Joe Sacco's Reporting on Iraq Cord A. Scott, PhD

REVIEW ESSAY

Charging Up San Juan Hill: Theodore Roosevelt and the Making

of Imperial America and In Command: Theodore Roosevelt

and the American Military

Reviewed by Keith D. Dickson, PhD

\section{BOOK REVIEWS}

Sand and Steel: The D-Day Invasions and the Liberation of France

Reviewed by Seth Givens, PhD

The First Day on the Eastern Front: Germany Invades the Soviet Union,

June 22, 1941

Reviewed by Colonel Douglas Nash Sr., USA (Ret)

Eisenhower: Becoming the Leader of the Free World

Reviewed by Zachary M. Matusheski, PhD

Treacherous Passage: Germany's Secret Plot against the United States

in Mexico during World War I

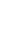




\section{VOTED NOTABLE GOVERNMENT DOCUMENTS}

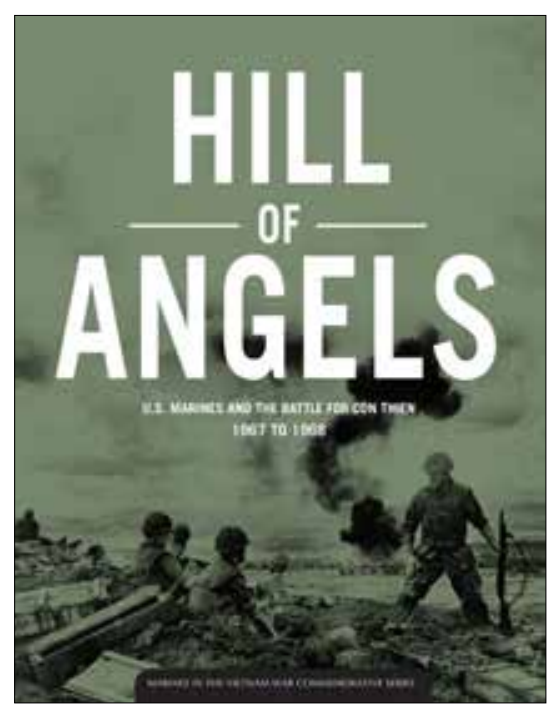

2016

Hill of Angels

U.S. Marines and the Battle for Con Thien, 1967 to 1968

by Joseph C. Long

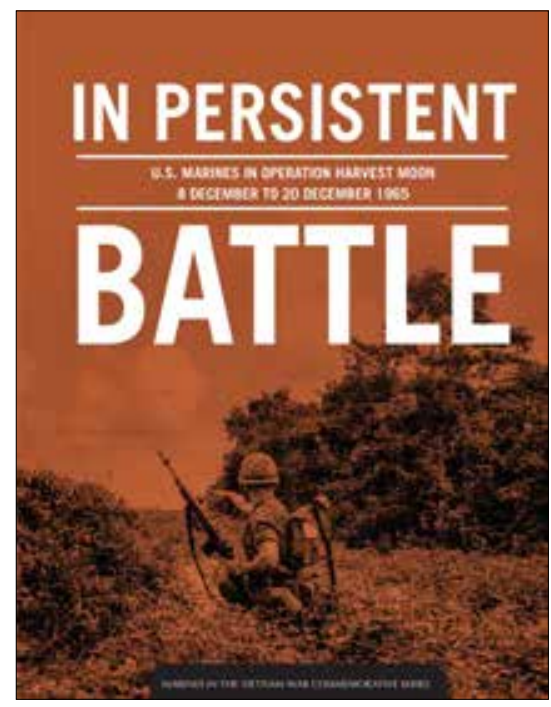

2017

In Persistent Battle

U.S. Marines

in Operation Harvest Moon,

8 December to 20 December, 1965

by Dr. Nicholas J. Schlosser

Always at War: Organizational Culture in Strategic Air Command, 1946-62

Reviewed by William E. Kelly, PhD

The Second Line of Defense: American Women and World War I

Reviewed by Zayna N. Bizri, PhD

The Veterans Cemeteries of Texas

Reviewed by J. Davis Winkie

The U.S. Army Campaigns of World War I: Into the Fight, April-June 1918

Reviewed by Ethan Lett

\section{Scholarly Debate}

Marine Corps History is a peer-reviewed, scholarly publication, and in that tradition we recognize that the articles published here are not the official or final word on any topic, merely the beginning of a conversation. If you think an author missed the target or failed to deliver, please join the debate by submitting an article for consideration. Email the managing editor at stephani.miller@ usmcu.edu for deadlines and author guidelines.

\section{Address Changes}

Do not miss a single volume of Marine Corps History because you have moved. Send a change of address request to mcu_press@usmcu.edu to update your subscription.

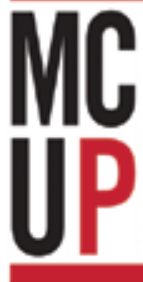

offers a variety of scholarly publishing opportunities for faculty, staff, and graduate-level students. In addition to a full catalog of monographs covering Marine Corps history and national security/international relations topics, MCUP also publishes three journals annually.

\section{Expeditions with MCUP \\ Expeditions with MCUP, an on- line academic journal, offers authors a forum for the debate of trending domestic and inter- national topics. Articles cover topics ranging from national security, international relations, political science, and geopoli- tics as they apply to and impact the Department of Defense, Department of the Navy, and Marine Corps.}

\section{Marine Corps History}

MCH is published twice a year on topics within the long history of the Corps: Civil War, Spanish-American War, Banana Wars, WWI, WWII, Korea, Cold War, Vietnam, Iraq, Afghanistan, and women and minorities in the military. Articles must focus on some aspect of the Corps, either directly or indirectly, including foreign marines and joint operations.

\section{JAMS}

The Journal of Advanced Military Studies focuses on topics within the international relations, political science, security studies, and political economics spectrum. Articles may discuss topics from a historical, contemporary, or forwardlooking perspective. The Fall 2020 journal focuses on naval integration. Article submissions due by May 2020 . 


\title{
DIRECTOR'S FOREWORD
}

\author{
Edward T. Nevgloski, PhD
}

I would like to start by wishing a happy New Year to all Marine Corps History readers. As the Marine Corps History Division enters 2020, it embarks on its second century of recording and preserving the history of the Marine Corps. Several changes have taken place since the last edition of this journal that I believe will play a critical part in how the division collects, maintains, and preserves that history during the next 100 years.

In November, the division underwent a few organizational changes in an effort to create more efficiencies and to better align its resources with current and emerging tasks. The first major change was to bring all historians together under one branch and focus them on a single task: writing the official operational and institutional history of the Marine Corps, including unit and base/station histories. The second change was to combine all historical resources-official records of the former Archives Branch and the working files of the former Historical Reference

Dr. Edward T. Nevgloski is the 28th director of the Marine Corps History Division and chief of Marine Corps History. He retired from the Marine Corps on 30 September 2017 at the rank of lieutenant colonel and with more than 28 years of service to the nation. His civilian education includes a bachelor's degree in history from East Carolina University in Greenville, NC; a master of arts in military history from Norwich University in Northfield, VT; and a doctor of philosophy in war studies from King's College, London. Dr. Nevgloski is also a graduate of the Marine Corps' Expeditionary Warfare School, Command and Staff College, and School of Advanced Warfighting.
Branch-under one Historical Resources Branch. With the former reference historians now solely focused on fulfilling the division's history writing mission, the tasks previously associated with the Reference Branch are now the responsibility of the Historical Resources Branch, staffed by the personnel of the former Archives Branch. This streamlining will enable Marine Corps History Division to more quickly respond to the requests for official written histories, research assistance, engagement with the Fleet Marine Forces and supporting establishment, and education and training directives it is likely to receive. Additional changes are on the horizon, as well, so stay tuned.

In this edition of Marine Corps History, we focus our attention on new events and evolving concepts of the twentieth century. Michael H. Decker and William Mackenzie recount the formation and evolution of Marine Corps Intelligence. Dr. Mary Elizabeth Walters recalls the Marine Corps' experiences in lesser-known operations other than war, particularly in Kosovo and northern Iraq. Colonel Peter T. Underwood, USMC (Ret), provides a study of the relationship between the Army's General John J. Pershing and the Marines during the First World War, which to some is remembered as rather tense but to others was not as antagonistic as it has been portrayed. Longtime History Division friend and contributor Dr. David J. Ulbrich questions whether the Marine operations in Haiti from 1926 to 1930 stabilized or further dis- 
rupted the situation there. Finally, Dr. Cord A. Scott offers an analysis of how comic books created by war correspondent Joe Sacco record the sights and sounds of war, including the experiences of Marines on the ground with whom he was embedded during the Iraq War.

As we enter into the next century of recording and preserving the Marine Corps' official history, new resources and research will enable historians to reexamine events, individuals, and concepts of the past and illuminate new perspectives and ways of thinking about them in order to answer the question "so what?" The age of recording official facts for the purpose of mere preservation is mostly behind us; we must now begin the process of placing events, concepts, ideas, and facts into their proper historical context, which will help determine the lessons that may be learned from them. This is no small task. It is, however, necessary if the Marine Corps' experiences are to remain relevant.

Semper Fidelis,

Edward T. Nevgloski, PhD

Director

Marine Corps History Division

and Gray Research Center

$\cdot 1775^{\cdot}$ 


\title{
General Pershing and the U.S. Marines
}

by Colonel Peter T. Underwood, USMC (Ret)

\begin{abstract}
It is widely believed that the Marine Corps' participation in World War I was only grudgingly allowed. The U.S. Army and General John J. Pershing are often cast as being vehemently opposed to Marines being assigned to frontline units or actively participating in combat. While there is no evidence that Pershing advocated against using Marines, other than his opposition to creating an all-Marine division, there is little direct evidence that he let his preference for the Army override his professional judgment in employing Marines in the American Expeditionary Forces. If the Corps ever had a bête noir, it seems it was General Pershing. However, while Pershing's personal views about Marines can only be surmised, his decisions on their employment in the AEF indicate that he was guided by the demands of war and military logic rather than personal pique. This article attempts to seek the truth of how Pershing's purported attitudes toward Marines affected his decisions regarding Marine employment in the AEF.

Keywords: General John J. Pershing, American Expeditionary Forces, AEF, Marines in World War I, anti-Marine sentiments, inter-Service rivalry, all-Marine AEF division, 4th Brigade of Marines, 5 th Brigade of Marines, Fifth Regiment, Major General George Barnett, Colonel John A. Lejeune, Brigadier General Charles Doyen, Brigadier General Smedley D. Butler, Brigadier General Eli Cole, Belleau Wood, Marine replacement strength
\end{abstract}

M ost Marines agree that the modern U.S. Marine Corps earned its right to be counted as one of America's premier fighting forces during World War I on the battlefields of France. Its success in those battles, especially the Battle of Bel-

Peter T. Underwood served in the Marine Corps for 29 years. His assignments included tours in $2 \mathrm{~d}$ and $3 \mathrm{~d}$ Marine Division, the $2 \mathrm{~d}$ and $3 \mathrm{~d}$ Force Service Support Group, and 1st Marine Aircraft Wing, with staff assignments in Europe and U.S. Atlantic Command, and as chief of staff, Marine Corps Logistics Bases Command. He commanded Marine Amphibious Unit Service Support Group 31 and the Albany Maintenance Depot, GA. He served in Operations Desert Shield, Desert Storm, and Desert Fox and is a recipient of the Combat Action Ribbon. He is a graduate of Virginia Military Institute, Duke University, the Air Command and Staff College, the Joint Forces Staff College, and the U.S. Naval War College. He served as an assistant professor of history at the U.S. Naval Academy and his final assignment was as professor of strategy and policy at the U.S. Naval War College. He retired from the Marine Corps in 2008.

https://doi.org/10.35318/mch.2019050201 leau Wood, gave birth to a Corps with a new vision of its capabilities and role in the defense of the United States.

But it is also widely believed that the Corps' participation in World War I was only grudgingly allowed. The U.S. Army and specifically General John J. Pershing are often cast as being vehemently opposed to Marines being assigned to frontline units or actively participating in combat. While there is no evidence that Pershing advocated against using Marines, other than his opposition to creating an all-Marine division, there is little direct evidence that he let his preference for the Army override his professional judgment in employing Marines in the American Expeditionary Forces (AEF).

The accusations of Pershing denying Marines any meaningful role in the AEF usually include: trying to 
subsume their unique culture into the Army's by forcing them to wear Army uniforms and use Army equipment; sidelining their participation by using them for labor parties; relieving the $4^{\text {th }}$ Brigade of its Marine Corps commander and replacing him with an Army general; envying the glory and recognition garnered by the Marines following their victory at Belleau Wood, attempting to prevent them from achieving even greater glory by limiting their participation in future battles; and, finally, preventing the creation of a Marine division.

As the AEF commander, Pershing is often accused of being personally responsible for all of these affronts and is said to have become "furious" when forced to accept the Marines into the AEF. As a result, one military warfare history instructor claimed, "his actions would become an outward and visible sign of an inward and seething resentment." If the Corps ever had a bête noir, it seems it was General Pershing.

Pershing's memoirs are very reticent regarding Marines. He wrote that the $5^{\text {th }}$ and 6th Marines became "a part of our forces at the suggestion of Major General George Barnett, then Commandant of the Marine Corps, and with my approval." He further commented that the AEF's 2d Division enjoyed an advantage in having the 5 th and 6th Regiments in its ranks, giving it "well trained troops" early in the war. ${ }^{2}$ These matter-of-fact statements indicate neither favoritism nor antipathy regarding Marines. They are hardly a ringing endorsement of the Marine Corps, but neither are they the comments of someone resentfully grinding an axe. While Pershing's personal views about Marines can only be surmised, his decisions on their employment in the AEF indicate that he was guided by the demands of war and military logic rather than personal pique.

An objective look at the relationship between the Marine Corps, the Army, and General Pershing suggests the friction between them was not necessarily one of jealousy and inter-Service rivalry. It was

\footnotetext{
${ }^{1}$ Maj Ralph Stoney Bates Sr., "Belleau Wood: A Brigade's Human Dynamics," Marine Corps Gazette 99, no. 11 (November 2015): 13.

${ }^{2}$ John J. Pershing, My Experiences in the World War (Blue Ridge Summit, PA: TAB Books, 1989), 321.
}

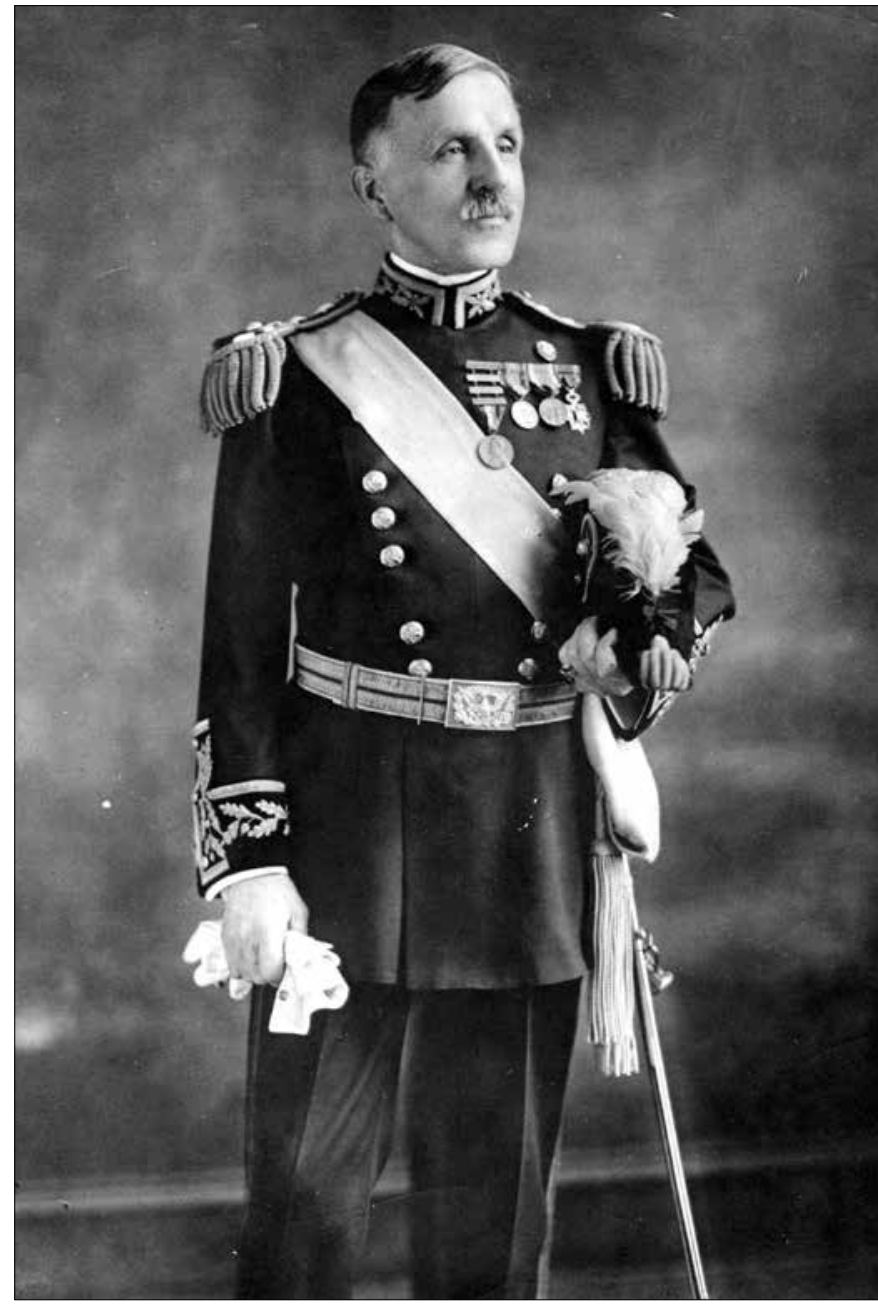

Official U.S. Marine Corps photo, Historical Reference Branch, Marine Corps History Division MajGen George Barnett, 12th Commandant of the Marine Corps.

more likely the result of natural bureaucratic friction as the Marines struggled to quickly integrate themselves into the machinery of the Army. While this friction certainly irritated the Marines, the Corps' leaders also recognized that its causes were legitimate and they addressed them as effectively as they could. This article attempts to seek the truth of how Pershing's purported attitudes toward Marines affected his decisions regarding Marine employment in the AEF.

\section{Organization and Equipment}

The National Defense Act of 1916 authorized the Marine Corps to increase its end strength from 13,700 to 15,600 with provisions to expand to 18,100 . This al- 
lowed the Corps to perform its primary mission of providing brigade-size advanced base forces and base security detachments for the U.S. Navy as well as a force to deploy and fight with the Army if the opportunity presented itself, as it had at Veracruz. ${ }^{3}$ Before this legislation was passed, the Commandant of the Marine Corps, Major General George Barnett, asked to meet with Secretary of War Newton D. Baker. Accompanied by his boss, Secretary of the Navy Josephus Daniels, and his able assistant Colonel John A. Lejeune, Major General Barnett met with Baker and the Army chief of staff and discussed the role of the Marines in the event of war. ${ }^{4}$

In this meeting, the Commandant "cajoled" the Army's leaders into accepting two regiments with the intent of forming a Marine brigade. 5 The Army agreed but did not issue a blank check. At the same meeting, Barnett "agreed to several administrative changes so as to outfit and organize the token leatherneck force along army lines." ${ }^{\prime \prime}$ In turn, Secretary Baker assured Barnett that the Army would provide the Marines with the equipment needed to bring the regiments up to the Army's tables of equipment so the Marine regiments would be "organized like the Army." This raises the question of why Major General Barnett and Colonel Lejeune agreed to these conditions. Were they forced into the agreement? Was the Army spitefully demanding the Marines look like soldiers? Were the Marines in such dire need of equipment that they felt compelled to agree?

Before World War I, the Corps, like the Army, organized itself into regiments. But unlike the Army, the Corps did not have a fixed structure below the regiment level. Its naval mission required Marines to deploy on various combinations of naval vessels, so

\footnotetext{
${ }^{3}$ Kenneth W. Condit, Maj John H. Johnstone, and Ella W. Nargele, A Brief History of Headquarters Marine Corps Staff Organization (Washington, DC: Historical Division, Headquarters Marine Corps, 1971), 10.

${ }^{4}$ Merrill L. Bartlett, Lejeune: A Marine's Life, 1867-1942 (Annapolis, MD: Naval Institute Press, 2012), 65.

5 Allan R. Millett, Semper Fidelis: The History of the United States Marine Corps (New York: Free Press, 1991), 290.

${ }^{6}$ Allan R. Millett and Jack Shulimson, eds., Commandants of the Marine Corps (Annapolis, MD: Naval Institute Press, 2004), 184.

${ }^{7}$ Millett, Semper Fidelis, 290.
}

the Corps used a flexible organization where the number of battalions and companies per regiment could be adjusted to match changing requirements. This ability to task organize was a strength when operating with the Navy. The problem was that when the Marines moved inland, away from the ships providing logistical support, they would then have to draw that support from the Army. ${ }^{8}$

As the clouds of war blew from Europe to America, Secretary Baker and the Army staff were also planning their own wartime requirements. They understood the Army would be expanding at an unprecedented rate, turning out combat divisions in a matter of weeks and months. To do this required a standard and uniform template. Every type of unit-infantry, artillery, engineer, or any other essential support unit-would all have to be the same in organization and equipment. Nonstandard units with unique requirements would be too difficult to manage.?

The AEF eventually exceeded 2 million troops. ${ }^{10}$ To this force, the Marines contributed 24,555 servicemembers organized into four infantry regiments and accompanying casualty replacement units. ${ }^{11}$ Four infantry regiments were hardly enough to cause the Army to adjust its planning system, but it was enough to complicate its sustainment system with nonstandard equipment and units with fluctuating numbers of fighters.

Anticipating the need for more than 1 million troops, the Army foresaw the need to quickly form infantry divisions at locations all over France. They explained to the Marine leaders that the only way they could effectively do this would be by imposing absolute uniformity in organization and structure. Secretary Baker expressed concern that the Marine Corps, with its flexible organization and supply system teth-

\footnotetext{
${ }^{8}$ George B. Clark, The Second Infantry Division in World War I: A History of the American Expeditionary Force Regulars, 1917-1919 (Jefferson, NC: McFarland, 2007), 190.

9 Clark, The Second Infantry Division in World War I, 11.

${ }^{10}$ American Armies and Battlefields in Europe (Washington, DC: Center of Military History, U.S. Army, 1992), 515.

${ }^{11}$ Maj Edwin N. McClellan, The United States Marine Corps in the World War (Washington, DC: Historical Branch, G-3 Division, Headquarters Marine Corps, 1968), 17.
} 
ered to the Navy, would be difficult to integrate into this rapidly expanding Army system. ${ }^{12}$

We can assume that General Barnett and Colonel Lejeune recognized and accepted this logic. They must have accepted the fact that if they were to achieve their goal of fighting in the coming war alongside the Army they would have to adapt. The meeting ended with Barnett and Lejeune assuring Secretary Baker that any Marine units going to Europe would fit smoothly into the machinery of the growing Army. ${ }^{13}$

The Commandant organized the two Marine regiments earmarked for Europe to mirror the Army's, with equal numbers of Marines organized in equal numbers of battalions, companies, and platoons. They would use the same equipment as the Army and, on deployment, would shift their system of supply from the Navy to the Army. Wearing the Army's olive drab uniforms seemed a small price to pay to ensure Marines a place in the line of battle.

The United States declared war against Germany on 6 April 1917, eight months after the Army agreed to Marines fighting next to soldiers and the Commandant decided those Marines would mirror the Army in organization and equipment. On 10 May 1917, Secretary Baker appointed General Pershing commander of the AEF, and on 29 May the Marines received the order to form the 5th Regiment. The Marines' prior planning to mirror the Army's table of organization and table of equipment resulted in the new regiment being manned, equipped, and ready to deploy in five weeks. ${ }^{14}$ The Corps realized its plan to fight in Europe beside the Army.

The charge that the Army, and particularly General Pershing, attempted to destroy the Marines' unique character by forcing them to change their table of organization to mirror the Army's, and to use Army equipment, to include the wearing of Army uniforms, simply does not stand up to the facts. The decision to change the Marine Corps' tables of organi-

\footnotetext{
${ }^{12}$ Clark, The Second Infantry Division in World War I, 11.

${ }^{13}$ Millett and Shulimson, Commandants of the Marine Corps, 184.

${ }^{14}$ Tom FitzPatrick, Tidewater Warrior: The World War I Years-General Lemuel C. Shepherd, Jr., USMC Twentieth Commandant (Fairfax, VA: Signature Book Printing, 2010), 121.
}

zation and equipment to mirror the Army's was made by the Commandant, not by General Pershing, and the decision was made before the United States entered the war and well before Pershing took command of the AEF. Further, the Marines were not shoehorned into the AEF against the Army's will. The secretary of war and Army chief of staff accepted the Marines once assured that Corps regiments would administratively fit into the Army's organizational structure. The Commandant made the decision to mirror the Army's organization and use its equipment months before the United States ever entered the war or Pershing took command of the AEF.

Perhaps more importantly, these decisions reflect the prescience and judgment of the Marine Corps' leaders, General Barnett and Colonel Lejeune. They recognized that the future of the Corps lay in proving its ability to fight in major land battles beside the Army, not insisting on retaining organizations poorly structured to the coming struggle or insisting on unique uniforms and equipment. The Corps' legend and lore should reflect this institutional flexibility, adaptability, and willingness to do what was required to ensure a meaningful position in the nation's defense, not a grudging acceptance of dictates from the Army.

\section{Rear Area Duties}

When Marines began arriving in France, many units were quickly scattered about the country attached to the Services of Supply (SOS), primarily as guards and labor parties. While rear area duties were distasteful to Marines, the decision to use them in this role came from hard military logic.

In virtually every conflict since the SpanishAmerican War, the U.S. military has faced the difficult decision of determining the mix of the first troops to deploy. When making an opposed landing on a hostile shore, it is logical that combat units arrive first. But when the landing is administrative, the decision is harder to make. Modern armies are dependent on vast amounts of logistical support. If service support troops are not available to perform essential support functions, combat units must do them themselves. 
When the first contingent of Americans arrived in France, it consisted primarily of the Army's 1st Division and the Marines' 5th Regiment. The support troops necessary to unload the ships, build and run the billeting and training camps, and establish essential supply depots were in very short supply. ${ }^{15}$ As the Americans began pouring in, the requirements to support them grew exponentially. It would be months before the SOS would have all the people needed to perform its mission. Even though helping perform these duties did not sit well with Marines, the reason for using them in that capacity is understandable.

General Pershing intended to commit his divisions to combat as a fully trained army, not individually as fillers for the depleted French and British divisions. To do this would take time-up to a year-as his divisions formed and trained in France. But he realized that a crisis might force him to commit whatever forces he had. In the first months of America's growing presence in the war, the 1st Division was Pershing's only fully manned, equipped, and trained division. If forced to commit American troops to combat before he fully formed his army, the unit to deploy would be the 1st Division, the only one fully ready for combat. ${ }^{16}$

While 5th Regiment was also fully manned, equipped, and trained, it lacked the ancillary support needed to sustain it in combat. Artillery, communications, engineers, transportation, and all logistical support had to come from the Army. Until another division could be formed using the 5 th and 6th Regiments as one of its brigades, the $5^{\text {th Regiment was }}$ just an "extra" regiment and not integral to the 1st Division as trying to attach it would only overtax the division's resources, slowing its own preparations for battle. With this logic, elements of 5 th and then 6 th Regiments were used to support the SOS until more support troops could arrive. Only then would the two regiments combine to form a Marine brigade. ${ }^{17}$

While the process of replacing Marines with sup-

\footnotetext{
${ }^{15}$ McClellan, The United States Marine Corps in the World War, 30.

${ }^{16}$ Maj James M. Yingling, A Brief History of the 5 th Marines, rev. ed. (Washington, DC: Historical Branch, G-3 Division, Headquarters Marine Corps, 1968), 3 .

${ }^{17}$ Clark, The Second Infantry Division in World War I, 186.
}

port troops took longer than the Marines would have liked, General Pershing proved true to his word and on 23 October 1917, the 4th Brigade raised its colors, becoming one of the two brigades of the $2 \mathrm{~d}$ Division along with the Army's 3d Infantry Brigade. ${ }^{18}$ Then on 16 January 1918, with Pershing's approval, the $4^{\text {th }}$ Brigade was officially redesignated the 4 th Brigade of Marines, a distinctly all-Marine unit. ${ }^{19}$

But even after the formation of the brigade, Marines continued to serve with the SOS in a variety of functions all over France as casualty replacements. The Marine Corps sent 14,500 officers and enlisted as casualty replacements, organizing them into 18 separate units. ${ }^{20}$ Most of these troops spent some period of time performing rear-area duties. While this may give the appearance that Marines were being spitefully singled out for noncombat duties, a closer examination suggests otherwise.

In July 1917, the AEF published The General Organization Project, specifying how it would replace its casualties and sustain its combat divisions and corps. Based on British and French practices, this document stated that to maintain two divisions in combat, each corps would need two additional divisions in reserve, allowing them to rotate in and out of the line. In addition to the support provided by the SOS, these four divisions needed another two divisions to provide administrative support in the form of training units, school units, base support units, replacement processing units, and positions at Corps- and Army-level units. ${ }^{21}$ This was the tax that had to be paid to sustain the combat units; the Marines were not exempt.

The administrative requirements to sustain large military forces are vast. The debate about the ratio of "tooth to tail" is always contentious, but to brush

\footnotetext{
${ }^{18}$ Maj Edwin N. McClellan, "The Fourth Brigade of Marines in the Training Areas and the Operations in the Verdun Sector," Marine Corps Gazette 5, no. 1 (March 1920): 81.

${ }^{19}$ McClellan, "The Fourth Brigade of Marines in the Training Areas and the Operations in the Verdun Sector," 81.

${ }^{20}$ Joel D. Thacker, "Replacement Personnel in World War I" (unpublished paper, Historical Section, G-3 Division, Headquarters Marine Corps, Washington, DC, 1942), 17-19.

${ }^{21}$ United States Army in the World War, 1917-1919, vol. 12, Reports of the Commander in Chief, Staff Sections and Services (Washington, DC: Center of Military History, U.S. Army, 1991), 142.
} 


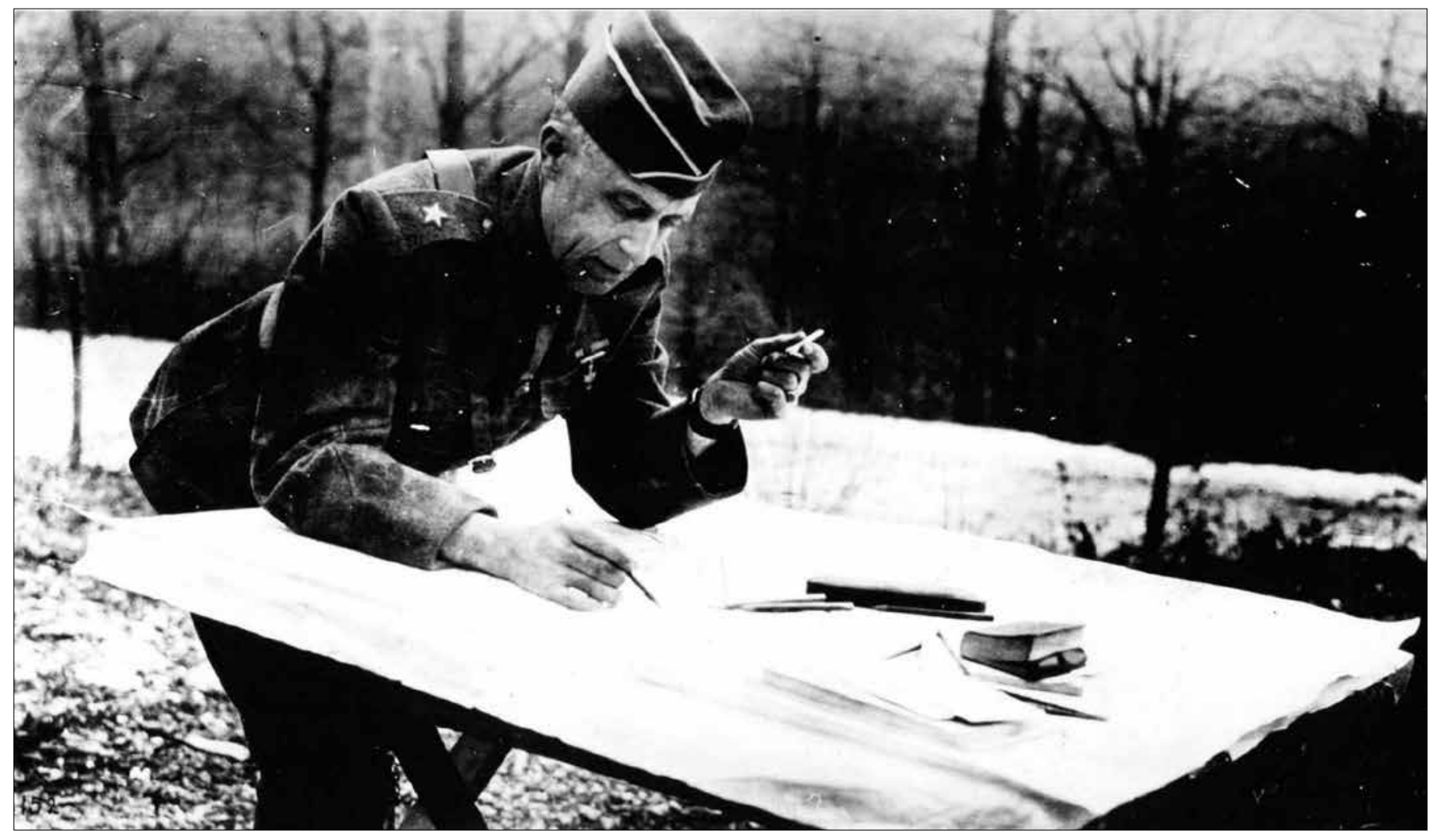

Official U.S. Marine Corps photo, Historical Reference Branch, Marine Corps History Division BGen Charles A. Doyen, commanding general, 4th Brigade, France, 1918.

away the requirements to support forces in the field is to ignore the realities of modern war. Maintaining a constant level of combat troops in the field demands a price. The Army based its support system on those of its allies. ${ }^{22}$ The Army's expectation that the Marine Corps would support these requirements was reasonable, and the Marine Corps met those obligations to the best of its ability. As the AEF grew in size and the demand for manpower swelled, it was not uncommon for Army units to send large detachments to perform similar support functions. To suggest that Pershing singled out Marines for rear-area support functions simply ignores the conditions in France necessary to support the combat divisions.

\section{Charles Doyen's Relief}

In April 1918, while the AEF was training in the

22. United States Army in the World War, 142-44. trenches of the Verdun sector, an incident occurred that Marines have ever since considered to be one of the most distasteful affronts inflicted on the Corps: General Pershing's relief of the 4th Brigade's commander, Brigadier General Charles A. Doyen. When

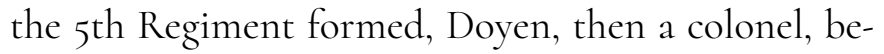
came its first commander. A seasoned campaigner, he was by all accounts everything a military officer could aspire to be: competent, committed, conscientious, devoted to his troops, and loyal to his superiors. When 6th Regiment arrived in France and General Pershing formed a Marine brigade, Doyen assumed command with the rank of brigadier general.

For 10 months, Brigadier General Doyen provided a skilled and guiding hand to the Marines in France. He formed the brigade and trained it under intense pressure and difficult conditions. The bond between the commander and his Marines was strong, and their trust in him was implicit. Then, on 29 April 
1918, while Doyen and his troops were in the trenches at Verdun training under combat conditions, General Pershing removed him from command, replacing him with an Army general. ${ }^{23}$

His relief was part of a larger effort to ensure that all general officers were up to the imminent physical challenges of combat. General Pershing observed that most of the general officers in France were old campaigners-old not only in experience but also in age. Their physical stamina and endurance to perform effectively in the harsh conditions of battle became a concern. An order was issued requiring every general in the AEF to undergo a comprehensive physical examination. Standards were established and those failing to meet them would be returned to the United States. ${ }^{24}$

Doyen and four other Army generals failed to meet the established requirements and they were all returned to the United States. ${ }^{25}$ Command of the Marine brigade passed to Army Brigadier General James G. Harbord, Pershing's chief of staff. Harbord quickly earned the trust, confidence, and loyalty of the Marines. In less than two months, he would lead them to victory in the Battles of Belleau Wood and Soissons. Doyen would die before the end of the year on 6 October 1918 at age 59, six weeks before the end of the war.

Replacing Doyen with an Army general was one of the more unpalatable events of the war for the Marine Corps. Even though Doyen failed to meet the established standards of an objective physical examination, his relief fueled rumors that General Pershing disliked Marines and had only accepted them under pressure from Washington. ${ }^{26}$

\section{Marines in the AEF}

Some Marines took Doyen's relief as a personal affront, never forgiving Pershing or the Army at large for this seeming slight against the Corps. While this

${ }^{23}$ McClellan, "The Fourth Brigade of Marines in the Training Areas and the Operations in the Verdun Sector," 107.

${ }^{24}$ George B. Clark, The Fourth Marine Brigade in World War I: Battalion Histories Based on Official Documents (Jefferson, NC: McFarland, 2015), 5-6.

${ }^{25}$ Clark, The Fourth Marine Brigade in World War I, 5-6.

${ }^{26}$ Clark, The Fourth Marine Brigade in World War I, 5-6. viewpoint appeals to those interested in fostering legends of inter-Service conflict, the actual record of Pershing's treatment of Marines indicates that if he had a prejudice, it was one in favor of their professional abilities. When he appointed Harbord to command the Marine brigade, there were no other Marine generals in France. Pershing had no other option.

When Harbord assumed command of the AEF's Services of Supply, the newly arrived Lejeune received command of the brigade and then three days later advanced to command its parent unit, the $2 \mathrm{~d}$ Division. ${ }^{27}$ This was not preordained and Pershing did not have to do it.

In World War I, the Army consisted of three types of divisions: Regular Army divisions, National Guard divisions, and National Army divisions, the last being the rough equivalent of a modern Reserve division. Without debating the merits of each type, the Regular Army divisions were generally considered the premier commands. On arrival, Lejeune initially received command of the 64th Infantry Brigade of the Wisconsin National Guard. Had General Pershing disliked Marines or doubted their professional competence, he could easily have left Lejeune in this command. Instead, he transferred him to command the coveted 4 th Brigade and then almost immediately advanced him to command the $2 \mathrm{~d}$ Division of the Regular Army. Along with the 1st and 3d Divisions, it was considered one of the AEF's premier assault divisions. ${ }^{28}$ Posting a Marine to command such a unit was hardly the action of a man with an axe to grind against the Marine Corps.

If Pershing harbored animosity against the Marine Corps, he certainly did not seem to express it in the assignment of individual Marines. He carried two Marines with him on his staff when he left for France. During the war, dozens of Marine officers filled positions of authority and responsibility throughout the AEF as commanders and staff officers. ${ }^{29}$ Only two of four Marine generals served in France and two commanded units in combat: Major General Lejeune, the

\footnotetext{
${ }^{27}$ FitzPatrick, Tidewater Warrior, 351.

${ }^{28}$ FitzPatrick, Tidewater Warrior, 351.

${ }^{29}$ McClellan, The United States Marine Corps in the World War, 38.
} 


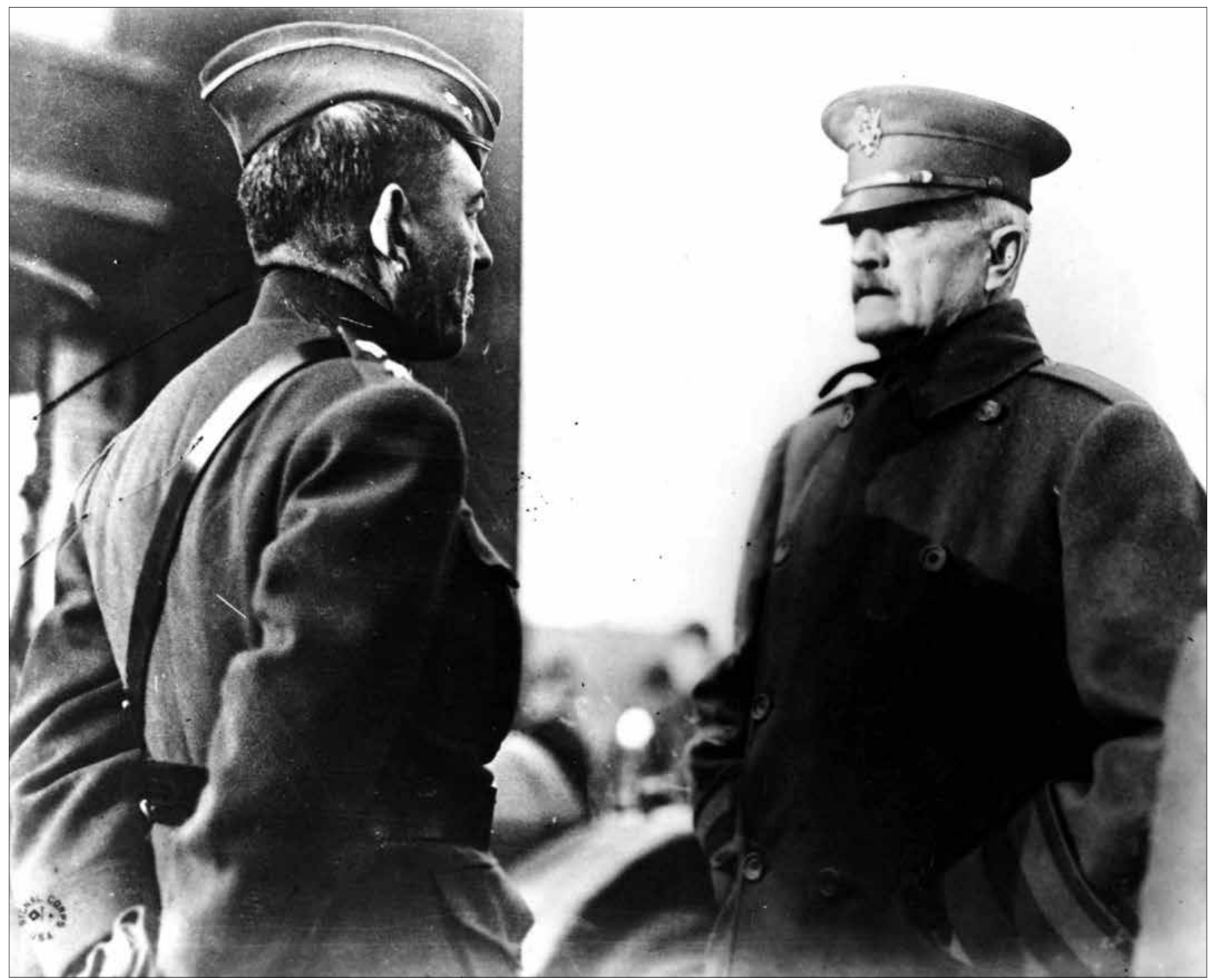

Official U.S. Marine Corps photo, Historical Reference Branch, Marine Corps History Division

Gen John J. Pershing and Gen John A. Lejeune, France, 1918.

first Marine to command a division in combat-and an Army division, at that-and Brigadier General Wendell C. Neville, who took command of the $4^{\text {th }}$ Brigade after Lejeune.

When the 5th Brigade arrived in France, its commander, Brigadier General Eli K. Cole, was promoted and briefly commanded the 41st Division during the final weeks of the war. He then commanded the 1st Replacement Depot at Saint-Aignan and finally the American Embarkation Center and Forwarding Camp at Le Mans. ${ }^{30}$ Brigadier General Smedley D. Butler commanded Camp Pontanezen in Brest, France. This was the AEF's primary depot for all arriving and departing troops. His job was to oversee the operations of the "largest embarkation camp in the world." ${ }^{11}$

In May 1918, there were in fact more field-grade officers in the 4th Brigade than it needed. This stood

${ }^{30}$ McClellan, The United States Marine Corps in the World War, 62.

${ }^{31}$ McClellan, The United States Marine Corps in the World War, 62. 
in contrast to the exponentially expanding Army that found itself short of senior officers with combat experience. Most Marine field-grade officers had extensive service and experience. As such, they were highly sought after for both command and staff positions, detaching to serve as battalion, regimental, and brigade commanders of Army infantry, machine gun, and artillery units.32 Throughout the war, Marine officers served almost continuously on the staffs of not only the $2 \mathrm{~d}$ Division but also the 1st, $3 \mathrm{~d}, 4 \mathrm{th}, 6 \mathrm{th}, 26 \mathrm{th}$, 32d, 35th, 9oth, and 92d Divisions.33

While it is common to focus on the use of Marines in what are generally considered unglamorous rear-echelon jobs, it should be remembered these jobs were essential, and the assignments were not a reflection on the Marines' professional abilities. Marines were generally prized for their abilities. Had General Pershing disliked Marines or held reservations about their abilities as soldiers, it seems unlikely he would have condoned their assignment to so many positions of authority and responsibility. The relief of Brigadier General Doyen was unquestionably an unsatisfactory event, but war is a hard business. When people's lives hang in the balance and victory is at stake, commanders must make hard decisions. That is something all Marines understand.

\section{A Place in the Line of Battle}

The 4th Brigade spent almost two months in the trenches near Verdun, but its first major test came at the Battle of Belleau Wood. The 4th Brigade's performance at Belleau Wood does not need to be recounted here, however. The glory and honors it garnered and the publicity it received propelled it and the Marine Corps into the forefront of the nation's consciousness.

Marine Corps lore often portrays Belleau Wood as an all-Marine battle in which the 4 th Brigade halted the German advance and saved Paris. It is often overlooked that while the Marines had an excess of field-grade officers, it was in short supply of junior

\footnotetext{
${ }^{32}$ McClellan, The United States Marine Corps in the World War, 36-37.
}

${ }^{33}$ McClellan, The United States Marine Corps in the World War, 36-37. company-grade officers; a shortage filled by the Army. Many of the small unit actions in this and the other battles of the war were led by Army officers serving in the brigade. In his memoirs, General Pershing clearly acknowledges the performance of the 4 th Brigade at Belleau Wood, but his account, perhaps to the annoyance of Marines, places the battle in the larger context, one fought by the ad Division, next to the $3 \mathrm{~d}$ Division's simultaneous combat at Château-Thierry. ${ }^{4}$

Without question, the 4 th Brigade deserves every honor it earned at Belleau Wood. The courage and tenacity it displayed during that battle have seldom been matched. But it is easy to forget that the 4 th Brigade never fought as an independent unit. It always fought as an integral part of the $2 d$ Division, which included the $3 d$ Infantry Brigade, ad Field Artillery Brigade, and its other organic units providing engineer, signals, supply, and sanitation support. ${ }^{35}$

The ad Division was a Regular Army division, one of the first three formed in France, and considered one of the Army's top three divisions. It fought prominently in every campaign of the war; the Aisne defensive, the Aisne-Marne offensive, the Saint-Mihiel offensive, and the Champagne offensive, where it was attached to bolster the French sector, assaulting and capturing Blanc Mont before returning to the U.S. 1st Army for the final Meuse-Argonne offensive. With the Armistice and the occupation of bridgeheads on the east bank of the Rhine, General Pershing again turned to the $2 \mathrm{~d}$ Division to serve in the Army of Occupation. If excessive publicity caused Pershing to want to keep the 4 th Brigade from the front lines after its performance at Belleau Wood, leaving it in the ad Infantry Division was not the way to do it.

The account of Chicago Tribune reporter Floyd Gibbons reporting on the actions of the Marines at Belleau Wood is almost as famous as the battle itself and does not need to be recounted here anymore than does the battle. There is no doubt that the Marines' unexpected publicity temporarily ruffled some feath-

\footnotetext{
${ }^{34}$ Pershing, My Experiences in the World War, go.

${ }^{35}$ McClellan, The United States Marine Corps in the World War, 38.
} 
ers. But there is no evidence that due to this publicity Pershing ever considered reassigning the 4 th Brigade to another division to prevent it from fighting in the coming battles, even if he did bear a professional grudge against the Marine Corps as an institution.

In the spring of 1918, the AEF still had not reached the level of proficiency that Pershing felt was essential before committing it to battle. But when the Germans launched their spring offensives in a final attempt to win the war, he came under intense political pressure to commit his forces. After Pershing finally agreed, the 1 st, $2 \mathrm{~d}$, and $3 \mathrm{~d}$ Divisions joined the defensive battles and helped halt the Germans. With the Aisne-Marne offensive immediately following and lasting into July, he was hard-pressed to ensure the American Army would be prepared to undertake the Saint-Mihiel offensive in early September. This first all-American offensive was quickly followed by an even larger Allied offensive, the Meuse-Argonne. With the intense pressure and focus required to manage these events, it seems unlikely that the commander of the AEF would have time to obsess about the publicity of a single brigade, even if it was a Marine brigade. There is no evidence that Pershing spitefully tried to prevent this single brigade, with its record of excellent performance, from fighting when it would require him to break apart one of his best-trained and combat-tested divisions. By all accounts, he had far more important things on his mind. If animosity did exist between General Pershing and the Marines, it was most likely not with the 4th Brigade, but rather with Headquarters Marine Corps in Washington, DC.

\section{The Struggle for a Division}

The Commandant, Major General Barnett, made no secret that he wanted to field a Marine Corps division. In turn, Pershing unquestionably opposed the formation of such a division. But the reason for his objection was more than professional pique or interService rivalry.

As with the other Services, the Marine Corps experienced numerous administrative challenges in expanding to meet the needs of World War I. Even though it expanded from 15,000 to 75,000 , it was still only able to send four infantry regiments to France, with casualty replacement units sufficient only for a single brigade. It was never able to deploy a single battery of artillery or any of the other combat support and combat service support units essential for a functional division. Had a Marine division been formed in 1918 , other than the infantry regiments, the Army would have had to provide all of the units required to make it a functional unit. At this time, the Marine Corps simply did not have the organizational and administrative capacity to field a fully capable division. $\mathrm{Had}$ the war lasted another year, the Corps might have been able to provide those capabilities, but it was never feasible during the war. By then, there was the even more pressing issue of replacing casualties.

Even though they analyzed the British and French experience of the previous three years, Americans never believed they would also suffer the same horrendous casualties on the western front. ${ }^{6}$ Despite the best efforts of American planners, by late summer 1918, the entire AEF experienced a crisis in manpower. The losses hit the Marines particularly hard, and during the relatively short period of six months of combat, they were hard-pressed to maintain their single infantry brigade.

When Major General Barnett met with Secretary of War Baker in 1916, he understood and quickly addressed the Army's concern about uniformity in organization and equipment. His adjustments ensured all Marine units joining the AEF would fit in seamlessly. But the Corps' ability to provide the casualty replacements needed to ensure its brigade could be sustained in combat was never fully addressed. The Army determined that even with the Marine Corps' five-fold expansion, it simply lacked the depth and organizational ability to sustain large combat formations given the expected casualties. Once committed to combat, if the Marines could not provide a steady flow of replacements, the all-Marine brigade would cease to exist through attrition, with soldiers rather than Marines filling its depleting ranks. If the Marines

\footnotetext{
${ }^{36}$ Clark, The Second Infantry Division in World War I, 12.
} 
could not ensure a reliable supply of troops, the logic of committing them to combat as a uniquely Marine Corps unit had to be questioned. It was the view of the War Department, the AEF, and Pershing that "while the Marines are splendid troops, their use as a separate division is unadvisable." 37 This view never changed; it was simply a matter of battlefield logic.

Manpower administration is a subject that attracts scant attention among military scholars and even less with students of military history. Those charged with its management gain little glory and, even when successful, tend to be ignored and forgotten. But administrative organization and depth, sufficient to meet the growing and unexpected demands of war, is essential. Without it, well-trained and competently led units imbued with esprit de corps cannot be sustained in the face of the inevitable attrition of battle.

From the Washington corridors of Headquarters Marine Corps to Major General Lejeune's field headquarters in France, ensuring the availability of fresh Marines was an issue of concern for the Corps' top leaders. Their efforts to supply the personnel needed to keep their single brigade at combat strength were herculean. They succeeded-but with little room to spare.

To understand why requires a general understanding of the AEF casualty replacement plan. To maintain its manpower, the AEF estimated that 2 percent of its strength would need to be shipped as replacements on a monthly basis. They later increased this estimate to 3 percent. The composition of replacements was 60 percent infantry and 40 percent for all other arms, including the services of supply. $3^{8}$ As previously discussed, the Marine Corps only provided infantry units. This relieved them from providing for the other arms and support units.

Soon after the $5^{\text {th }}$ Regiment arrived in France in June 1917, General Pershing asked the Commandant for three replacement battalions to start building

37 George B. Clark, Devil Dogs: Fighting Marines of World War I (Novato, CA: Presidio Press, 1999), 390-91.

${ }^{38}$ United States Army in the World War, 142-44. the Marines' replacement pool. This number quickly increased to five battalions. ${ }^{39}$ The first unit raised to meet this need was the 5 th Regiment Base Detachment. ${ }^{\circ}$ With 1,200 men organized into one machine gun and four rifle companies, these were the only Marine Corps replacements in France until December $1917 .^{41}$ In December, the War Department notified Headquarters Marine Corps that it needed to send three more battalions of replacements to conform to the current plan of having replacements equal to 50 percent of the combat forces. Then in January 1918 , the AEF increased the requirement from three battalions to five to provide cadres for advanced training units. ${ }^{42}$

This set in motion a process that sent an additional battalion from Quantico nearly every month for the rest of the war. ${ }^{43}$ These units deployed to France based on monthly requests from the AEF as well as Headquarters Marine Corps' own determination for replacements. A total of 204 officers and 14,358 enlisted eventually deployed to France as replacements. Despite these numbers, the 4 th Brigade still relied on the Army for personnel. In addition to the 65 officers and 375 enlisted provided by the Navy as chaplains, doctors, corpsmen, dentists, and dental technicians, the Army ultimately provided six Regular Army officers and two men, three National Army officers, 109 Infantry Reserve Corps officers, 29 officers and 27 enlisted men from the Medical and Dental Corps, 7 chaplains, 8 Veterinary Corps officers, and 7 officers and 80 enlisted men from the Signal Corps. ${ }^{44}$

Once engaged in battle, these numbers proved sufficient to keep the brigade at its table of organization strength of 8,469 . But with 12,00o casualties and a 150 -percent replacement rate, along with the administrative toll to support the larger AEF, it was barely sufficient. If the 5 th Brigade had been committed to

\footnotetext{
${ }^{9}$ LtCol Charles A. Fleming, Capt Robin L. Austin, and Capt Charles A. Braley III, Quantico: Crossroads of the Marine Corps (Washington, DC: History and Museums Division, Headquarters Marine Corps, 1978), 32. ${ }^{40}$ Fleming, Austin, and Braley, Quantico, 26.

${ }^{41}$ McClellan, The United States Marine Corps in the World War, 34.

${ }^{42}$ Thacker, "Replacement Personnel in World War I," 19-24.

${ }^{43}$ Fleming, Austin, and Braley, Quantico, 32.

${ }^{44}$ Thacker, "Replacement Personnel in World War I," 17-19.
} 
combat, there would be more casualties, generating an even greater demand for replacements.

Considering the Corps' difficulty in maintain the strength of a single brigade in combat, Pershing's concerns about the Marines' ability to sustain themselves seems justified. It also helps explain his resistance to combining the 4 th and 5 th Brigades to form a Marine division.

Almost as soon as the Marines arrived in France, the Commandant, Major General Barnett, began peppering Pershing with inquiries about how he was employing them, when they would form a brigade, and the possibilities of forming a division with the arrival of a second brigade. ${ }^{45}$ While Pershing likely understood Barnett's concern for his men, being constantly second-guessed by Washington and pressured to accommodate fewer than 30 ,ooo men out of more than 2 million must have worn thin rather quickly.

When Major General Lejeune arrived in France, he brought a letter from the Commandant to General Pershing. It proposed that the Marines provide one or more divisions to the AEF. As previously noted, this would require breaking up the $2 \mathrm{~d}$ Division just as the first all-American offensive was about to begin. Pershing had also expressed his reservations about forming a Marine division, based on the perceived inability of the Marine Corps to replace its ever-growing list of casualties. In a letter to Secretary of War Newton Baker, Pershing commented on the proposal with an emphatic "No." He later stated: "Referring to my conversation with the Secretary ... on this subject, I am still of the opinion that the formation of such a unit [a Marine Division] is not desirable from a military standpoint." ${ }^{\text {66 }}$

The obvious retort to his objections to forming a Marine division because of concerns over manpower is that if Marines had not been diverted to innumerable duties with the SOS, they would have been available as casualty replacements, the sole reason they had been sent to France. But this argument does not stand up under scrutiny.

\footnotetext{
45 Bartlett, Lejeune, 69.

${ }^{46}$ Clark, Devil Dogs, 390-91.
}

The 4th Brigade entered the Aisne defensive at its table of organization strength of 8,459 . The casualties suffered during the June and July battles triggered a call for replacements, which Headquarters met by sending roughly two battalions a month for the rest of the war. ${ }^{47}$ From the start, this effort was barely sufficient. A large number of replacements were already in France, but the need to augment the administrative establishment of the AEF was significant. When these numbers were added to the casualties incurred in battle, it meant the Marines suddenly needed to provide approximately 5 ,ooo troops to maintain the 4th Brigade's combat strength. ${ }^{8}$ This triggered a crisis never fully resolved during the war.

During June 1918, the 1st, 2d, 3d, and 4th Replacement Battalions provided 2,471 fighters, augmented by an additional $55^{\circ}$ casualties who were returned to duty. This total of 3,021 replacements against a requirement of 5,ooo, gave the 4th Brigade only 6,137 troops, roughly 2,ooo short of its required strength, with no more replacements available in France. The next large group of Marines in France had been assigned as AEF training cadres and could not be released without first having their own replacements. ${ }^{49}$

By 17 July, the eve of the Aisne-Marne offensive, the brigade was up to 7,037 troops. But by 1 August, when it withdrew from Soissons, its ranks had been depleted to 4,959 , more than 2,500 short with no replacements available other than returning casualties. The situation was so dire that the AEF staff notified Major General Lejeune, the ad Division commander, that if Marine replacements could not immediately be obtained, Army replacements would fill the gap. ${ }^{50}$

This was the situation Pershing had feared and the Marine Corps had sought to avoid. Its impact was fully understood by both Lejeune and Barnett. The Commandant, who had struggled so hard to ensure Marines left for France with the first detachment of American troops and who had contentiously pressed Pershing to assign the Marine brigade to a combat di-

${ }^{47}$ Fleming, Austin, and Braley, Quantico, 32.

${ }^{8}$ Thacker, "Replacement Personnel in World War I," 24.

49 Thacker, "Replacement Personnel in World War I," 24.

$5^{\circ}$ Thacker, "Replacement Personnel in World War I," 25. 
vision despite the concerns of Pershing and the AEF staff, now faced the prospect of seeing the brigade's Marine Corps identity erased through battlefield attrition unless he could quickly feed more Marines to the front lines. The seriousness of the situation and the Marine Corps' inability to quickly and definitively resolve the problem are reflected in a letter from the Commandant to Lejeune dated 14 August 1918:

Have just organized and sent to France the $3 \mathrm{rd}, 4 \mathrm{th}, 5 \mathrm{th}$, and 6th, Separate Battalions with a total enlisted strength of 3800 . In addition the First Separate Machine Gun Battalion, with a total enlisted strength of 500 has been organized and will leave before the end of the month. This makes a total of about 18, ooo men that we have dispatched to France for the maintenance of the one Brigade. Today a cablegram received from General Pershing making requisition for September replacements as follows: Infantry 3,500, Machine Gunners 1,ooo. If this order stands, it means that we will have by the end of September 22,500 men in France for the Fourth Brigade and with no way of estimating what is to follow. You can easily imagine the predicament this leaves us in, especially as regards furnishing the new brigade with its replacements.

To further complicate the matter, the President has just issued an order stopping all enlistments in the Navy and Marine Corps, and recruiting will probably be stopped for a month or more. We have about 12,000 men at Parris Island under training and awaiting completion of enlistment, and we will be alright for the next two months, but after that, there will be a period (the length of which will depend upon the length of time during which recruiting is stopped) when recruit depots will not turn out any men and the question of replacements is going to be a very serious one. Of course over here we cannot form any idea of what the situation is in France, but it seems like there must be a large number of Marines scattered around in France, not available at the present time for replacements. If you get the chance, therefore, I wish you would try to take up the question with General Pershing or someone on the General Staff, and see if you cannot get all of the scattered detachments ordered into our replacement organization. $^{51}$

The battalions Major General Barnett referenced in this letter would not be in France until 2 September, hardly enough time to process and integrate the new troops into the brigade before the launching of the Saint-Mihiel offensive on 12 September.52 Major General Lejeune found himself in a tough position. As the commanding general of $2 \mathrm{~d}$ Division, his primary responsibility was to ensure his division was ready when the offensive began, even if it meant filling the $4^{\text {th }}$ Brigade with soldiers. But as the senior Marine Corps officer in France, and the one who guided the effort to ensure a Marine brigade would fight with the Army, he certainly felt compelled to explore every avenue to ensure Marines filled the brigade's ranks.

On the eve of the first all-American operation, Lejeune certainly realized that Pershing had greater issues to deal with than the casualty replacements of a single brigade. He likely felt it prudent not to raise this issue with the commanding general. Instead, he contacted his friend from days as a student at the Army War College, the former $4^{\text {th }}$ Brigade commander, Major General Harbord, now commanding the SOS that had absorbed so many Marines. Lejeune requested that Harbord send all Marines with the

${ }^{51}$ Thacker, "Replacement Personnel in World War I," 25-26.

${ }^{2}$ McClellan, The United States Marine Corps in the World War, 30-34. 
SOS who were fit for combat duty to the 4 th Brigade. Harbord came to the aid of his friend and old brigade, immediately releasing Marines with the SOS from all over France. By 31 August, the brigade's strength was up to 6,836 , still far from full strength. Lejeune was compelled to notify 1st Army Headquarters that he needed 1,700 more replacements. ${ }^{33}$

The crisis soon resolved itself, at least in G-1s ledgers of the ad Division, I Corps, and First Army. Between 5 and 11 September, 2,ooo Marine Corps replacements were assigned to the brigade, bolstering its rolls to combat strength. But, in fact, the $3 d$, 4 th, and 5 th Separate Battalions did not leave the rear areas to join the brigade until 8 September. Confusion and delays in transportation prevented their reaching the brigade until the night of 11-12 September, the eve of the Saint-Mihiel offensive. With the brigade already in the trenches poised to attack, getting the replacements to their assigned companies and platoons proved problematic. How many servicemembers actually reached their units before the assault began will never be known, but the brigade's muster rolls list approximately 30 percent of the replacements as joining their units on 16 September, the day the offensive ended. 54

Fortunately, the Saint-Mihiel offensive exacted a light toll with only 132 killed and 574 wounded. The Champagne offensive would not be as gentle. The brigade strength on 1 October 1918 stood at 7,560. In the near-continuous fighting during 2-10 October, 494 troops were killed and 1,864 wounded. By 12 October, Lejeune needed more than 1,000 replacements for the

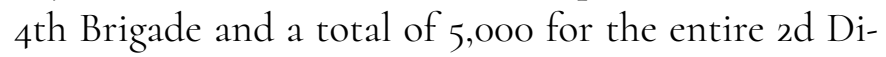
vision. ${ }^{5}$

On the night of $30-31$ October, the 4 th Brigade reached its frontline position to begin its final attack as part of the Meuse-Argonne offensive. Its assault through the Ardennes was brutal. When the Marines reached the banks of the Meuse on 11 November, their ranks were depleted. On 14 November, the 4th Brigade

\footnotetext{
53 Thacker, "Replacement Personnel in World War I," 25-26.

54 Thacker, "Replacement Personnel in World War I," 26-27.

55 Thacker, "Replacement Personnel in World War I," 26-27.
}

requested an additional 2,80o infantry, zoo machine gunners, and 40 second lieutenants. The only available infantry replacements in France were two battalions that had landed on 3 November. They would not arrive at the American training base at Saint-Aignan until 14 November. There were no available machine gunner replacements. The commanding general of Base Section 5, which controlled Camp Pontanezen, was ordered to strip 200 fighters from the 5 th Brigade Machine Gun Battalion and forward them to the 4 th Brigade..$^{6}$

When the replacement battalions reached SaintAignan on 14 November, they immediately passed through, leaving the following day with virtually no preparation or training. They arrived at the Dun-surMeuse railhead the evening of 16 November. They immediately began marching to join the brigade at its last position east of the Meuse only to find it was no longer there. As one of the divisions to participate in the Army of Occupation, the ad Division was already marching toward the Rhine. The replacements followed in trace, picking up the pace and joining the brigade the evening of 20 November in the town of Arlon, Belgium. ${ }^{7}$

The last Marine replacement unit to leave the United States, the 9th Separate Battalion, arrived in France on 9 November..$^{8}$ With the Armistice declared two days later, the replacement crisis was over, but the situation had been critical. By the time the Armistice was announced, every replacement unit, even if not every Marine in those units, had been forwarded to the $4^{\text {th }}$ Brigade, and still, the $5^{\text {th }}$ Brigade had to provide 200 troops. 59

If there had been no Armistice on 11 November, the brigade's casualties would almost certainly have continued to rise. Based on the bleak assessment from Headquarters, the only viable option for Marine replacements would have been the further stripping of people from the $5^{\text {th }}$ Brigade. This assumes the AEF would even have agreed to use the $5^{\text {th }}$ Brigade as a

\footnotetext{
${ }^{6}$ Thacker, "Replacement Personnel in World War I," 28.

57 Thacker, "Replacement Personnel in World War I," 28.

$5^{8}$ McClellan, The United States Marine Corps in the World War, 30-34.

59 Thacker, "Replacement Personnel in World War I," 28.
} 
replacement pool, which is questionable. This would have given credence to Pershing's objections to fielding a Marine division, or even employing a second Marine brigade as part of another division, based on his concerns about the Marine Corps' ability to provide sufficient replacements. From the perspective of the most efficient use of available manpower to meet immediate combat requirements, it seems likely that 4th Brigade replacements would have increasingly been soldiers, not Marines. If the war had continued with the brigade sustaining casualties at the same rate, another major offensive would have likely meant the 4th Brigade would have been composed primarily of soldiers. While distasteful to acknowledge, in retrospect, Pershing's objections to fielding a second Marine brigade or a division seem justified.

\section{Conclusion}

While General Pershing can hardly be called a friend of the Marine Corps, an honest appraisal cannot cast him as a vehement antagonist, as he is often portrayed. In the instances discussed, either decisions had been made before he assumed command of the AEF, or, when he did make decisions adversely affecting the Marines under his command, they were based on the requirements as he saw them at the time. There is no evidence, other than conjecture, that Pershing based his decisions on personal animosity toward the Corps.

The decision to assign Marines to the AEF was made long before Pershing assumed command. While the Commandant intended that the two attached regiments form a brigade, once the Marines detached from the Department of the Navy and joined the Department of the Army, they became a part of the AEF. As its commander, General Pershing was free to use them as he deemed fit and was under no obligation to use them according to the Commandant's desires. But he did, keeping his word to form the brigade and then assign it as an organic brigade of the $2 \mathrm{~d}$ Division. He approved its redesignation from the 4 th Infantry Brigade to the 4 th Brigade of Marines, and raised no objections when its troops were authorized to wear the Eagle, Globe, and Anchor on their Army uniforms.
Pershing could have interfered with these actions, but he did not.

His opinion of the Marines is best illustrated in how he used them, not in what he might have thought about them. He assigned the 4th Brigade to the $2 \mathrm{~d}$ Division, a Regular Army division. As such, it participated in every major operation in which the AEF participated. Once battle was joined, the only time the brigade and its parent division were not fighting was when the AEF was not fighting.

His use of Marine field-grade officers throughout the AEF further reflects his regard for their abilities. These officers commanded Army battalions, regiments, and brigades. They served on the staffs of units at every level. Even in rear-area duties, Marines were in positions of importance with training units and large personnel centers responsible for ensuring the smooth flow of personnel to and from the front.

As volunteers who joined to fight, those standing guard in supply depots were not doing what they had hoped. But even larger numbers of Marines who volunteered to fight the Germans spent the war on the Mexican border or Caribbean islands, waiting for combat that never came. All members of the military execute their orders, regardless of where those orders send them.

He clearly opposed the formation of a Marine division and opposed the commitment of a second brigade of Marines to battle, but those objections were based on two irrefutable facts. In 1917-18, the Marine Corps lacked the ability to field a fully capable infantry division, and the ability of the Corps to quickly and reliably replace the large number of expected casualties was, at best, questionable. An honest examination of the record shows that both of these concerns remained valid for the duration of the war.

For Marines to dwell on perceived slights during World War I seems fruitless. Pershing's placement of the Marine brigade in the ad Division gave the Corps the opportunity to prove, beyond any doubt, that they were more than just a naval landing party. They proved that they could successfully fight next to the best regiments of the Army and against what was considered one of the best armies in the world. This 
helped secure their future role in America's defense establishment, and for that, some degree of recognition is due to General Pershing.

If Pershing's concern about the institutional ability of the Marine Corps to field a fully capable infantry division strikes a nerve or if his concern for the Corps' ability to ensure it could sustain its units in the face of heavy casualties is painful to admit, the Corps' leaders at the time saw these criticisms for what they were: legitimate weaknesses that needed to be corrected.

The interwar period is remembered as the time when the Marines' search for a mission produced the amphibious doctrine that won World War II in the Pacific. But clearly, time was also invested in correcting the institutional shortcomings that were so apparent during World War I. Postwar reductions shrank the Marines back to their prewar strength of 15,000 , where they remained for the next two decades. But the administrative lessons of World War I were fully absorbed, and when World War II came, the Marines were prepared to expand rapidly. The ability to produce a fully capable division was no longer an issue. Far from just fielding a single all-infantry brigade, before the war's end, the Marines fielded six divisions with six supporting air wings, organized into two corps-level commands. Without the willingness to accept the hard-learned lessons of World War I, this may not have been possible. If General Pershing had not assigned the 4th Brigade to the $2 \mathrm{~d}$ Division, those lessons may never have been learned.

Still, when the casualty lists exceeded all expectations, it created a crisis in manpower that lasted until the war's end. The Marine Corps sustained its one combat brigade and met its requirement to augment the AEF's supporting establishment, but only barely. 


\title{
Stability or Disruption \\ THE U.S. MARINE OCCUPATION AND THE VOODOO TRIALS IN HAITI, 1926-30
}

by David J. Ulbrich, PhD

\begin{abstract}
The Marine occupation of Haiti from 1915 to 1934 presented unique challenges due to social, political, economic, and religious factors. All these threads came together in the Marines' attempts to curtail the practice of Voodoo. The religion's hold on Haitians proved to be so strong that no analysis of the Marine occupation can be thorough without paying careful attention to Voodoo. Institutional histories of the Marine Corps and studies of the Marine occupation of Haiti tend to sidestep analyzing Voodoo in detail or to misconstrue its significance. Conversely, cultural histories of Haiti rarely incorporate sufficient explanations of the operational aspects of the occupations, nor do they dig deeply into the Corps' archival sources. This article helps to fill the void by using the Marine activities and the Voodoo trials in the late 1920 as touchstones, analyzing several criminal prosecutions against Haitians for allegedly practicing Voodoo in that period. These cases underscore the rationale behind the Marines' attempts to "stamp out" this religion as part of their mission to transform Haiti into a modern, democratic, civilized nation and illustrate how Marines too often failed to grasp that Voodoo could support stability rather than rallying the Haitian people against the American presence and disrupting the modernization process. Keywords: Voodoo, Vaudou, Vodoun, Vodou, Voudu, Vaudoux, Voodoo trials, Haiti, Banana Wars, small wars, nation building, modernization, Haitian occupation, American intervention, Marines in Haiti, Dollar Diplomacy, Monroe Doctrine, Roosevelt Corollary, corvée system, Aux Cayes Massacre
\end{abstract}

B etween 1898 and 1934, thousands of U.S. Marines deployed to several nations in Latin America and the Caribbean Sea in efforts to stabilize the region by military force. The Marines

David J. Ulbrich directs the online master of arts in military history program at Norwich University in Northfield, VT. His first book, Preparing for Victory: Thomas Holcomb and the Making of the Modern Marine Corps, 1936-1943 (Annapolis, MD: Naval Institute Press, 2011), won the Gen Wallace M. Greene Jr. Prize from the Marine Corps Heritage Foundation. More recently, Ulbrich coauthored Race and Gender in Modern Western Warfare (Berlin: DeGruyter Oldenbourg, 2018) with Bobby A. Wintermute. This article draws on three shorter presentations at Norwich University in 2019 and the Society for Military History conferences in 2008 and 2018. Ulbrich gratefully acknowledges constructive comments of the referees, as well as the advice and assistance of Abel A. Alves, Trevor K. Plante, Emily Gray, and Bobby Wintermute, and of Annette Amerman, Stephani Miller, Fred Allison, and Yvette House of Marine Corps History Division.

https://doi.org/10.35318/mch.2019050202 tried to create democratic institutions, bolster indigenous military forces, protect American investments, deter European intrusions, and quell indigenous rebellions. These interventions and ongoing occupations were grafted onto the Marine Corps' institutional identity in what became known officially as small wars or more colloquially as Banana Wars. Among the deployments in the region, the occupation of Haiti from 1915 to 1934 presented unique challenges because of social, political, economic, and religious factors. All these threads came together in the Marines' attempts to curtail the practice of Voodoo (Vodou in Creole). The religion's hold on Haitians proved to be so strong

${ }^{1}$ Other spellings include Voudu in French, as well as Vaudou, Vodoun, and Vaudoux. See Harold Courlander, "The Word Voodoo," African Arts 21, no. 2 (February 1988): 88, https://doi.org/10.2307/3336535. 
that no analysis of the Marine occupation can be considered thorough without paying careful attention to Voodoo.

Institutional histories of the Marine Corps and studies of the Marine occupation of Haiti tend to sidestep analyzing Voodoo in detail or to misconstrue its significance. Conversely, cultural histories of Haiti rarely incorporate sufficient explanations of the operational aspects of the occupations, nor do they dig deeply into the Corps' archival sources. Even in Hispanic history journals, few scholarly articles have focused on the Marine occupation. The same can be said of diplomatic histories of Haiti that offer relevant analyses of policies yet set aside the operations in the conflict. $^{2}$

This article helps to fill the void by using the Marine activities and the Voodoo trials in the late 1920 s as touchstones. After briefly surveying the history of Haiti between 1492 and 1915, this article turns to the circumstances that spurred the Marine occupation of Haiti. Next, an explanation of the intertwined violence, corruption, and exploitation in Haitian soci-

\footnotetext{
${ }^{2}$ For example, although Allan R. Millett devotes part of one chapter to the occupation of Haiti in his seminal survey Semper Fidelis: The History of the United States Marine Corps, rev. ed. (New York: Free Press, 1991), he does not deal with the influence of Voodoo. The same can be said of James H. McCrocklin's compilation Garde D'Haiti, 1915-1934: Twenty Years of Organization and Training by the United States Marines (Annapolis, MD: Naval Institute Press, 1956); Hans Schmidt, Maverick Marine: General Smedley D. Butler and the Contradictions of American Military History (Lexington: University Press of Kentucky, 1987); and Keith B. Bickel's sociological study Mars Learning: The Marine Corps' Development of Small Wars Doctrine, 1915-1940 (Boulder, CO: Westview Press, 2001). Mary A. Renda deals in detail with Voodooism, racism, and paternalism in her landmark book Taking Haiti: Military Occupation and the Culture of U.S. Imperialism, 1915-1940 (Chapel Hill: University of North Carolina Press, 2001). However, Renda did not fully comprehend the operational contexts of the Marines in Haiti. Of the books on Marine Corps history used for this article, only Robert Debs Heinl and Nancy Gordon Heinl's Written in Blood: The Story of the Haitian People, 1492-1971 (Boston, MA: Houghton Mifflin, 1978) examines Voodoo in Haiti during the occupation. The Heinls, however, were likely not privy to the primary source documentation referred to in this article. Between 1949 and 2015, only 48 articles focused on the Marine occupation of Haiti out of 355 articles published in scholarly journals on Haiti, the Caribbean, Postcolonialism, or Latin American Studies. The vast majority of the remaining articles concentrated on the revolutionary period of 1793-1804. See Raphael Dalleo, American Imperialism's Undead: The Occupation of Haiti and the Rise of Caribbean Anticolonialism (Charlottesville: University of Virginia Press, 2016), 10-13.
}

ety provides context for Voodoo's integral role in the Haitian way of life. This article then analyzes several criminal prosecutions against Haitians for allegedly practicing Voodoo in the late 1920s. These cases underscore the rationale behind the Marines' attempts to "stamp out" this religion as part of their mission to transform Haiti into a modern, democratic, civilized nation. ${ }^{3}$ The conclusion reveals that the Marines too often failed to grasp that Voodoo could support stability rather than rallying the Haitian people against the American presence and disrupting the modernization process.

\section{Haitian History and Voodoo Practices, 1492-1898 ${ }^{4}$}

When Christopher Columbus made landfall on Hispaniola in 1492 , he found a large tropical island lying to the east of Cuba in the Caribbean Sea. The nation of Haiti eventually comprised the western one-third of the Hispaniola. In the three centuries that followed, the Spanish and-after 1697-the French empires subjugated the indigenous peoples by force and imported hundreds of thousands of enslaved people from Africa to work on plantations growing the area's primary cash crop, sugarcane. Lives were cheap in Haiti: slaves worked until they died, and then the Spanish or French purchased more to replace them.

Enslaved Africans brought several religions with them from Africa to Haiti, including Voodoo. This religion's followers believed in unity of all creation and served their chosen loa (spirits) who, while not deities themselves, served the powerful god Bondye. Rituals and ceremonies included combinations of prayers, songs, banging drums, animal sacrifices, an-

\footnotetext{
${ }^{3}$ John H. Russell applied the term stamp out (seen here, the article's title, and elsewhere in this article) to Voodoo in Haiti. See John H. Russell, Some Truths about Haiti, John H. Russell Papers, box 3, folder, Archives Branch, Marine Corps History Division, Quantico, VA.

${ }^{4}$ Much of the material in this section on Haitian history is drawn from Philippe Girard, Haiti: The Tumultuous History-From Pearl of the Caribbean to Broken Nation (New York: St. Martin's Press, 2010), 1-80; and Leon D. Pamphile, Contrary Destinies: A Century of America's Occupation, Deoccupation, and Reoccupation of Haiti (Gainesville: University Press of Florida, 2015), 1-17.

5 The term Bondye is derived from the French term bon Dieu, meaning "good God."
} 
cestor veneration, and spiritual possessions. In the last of these, people induced a trance state, as if possessed by the loa, who spoke and acted through them. The Haitians hoped their faith would attract loa, who in turn would bestow success on them. Voodoo remains important within Haitian culture into the twentyfirst century. The religion helped the enslaved peoples to cope with their plights in life and galvanized their resistance against the Spanish, French, and eventually American Marines. ${ }^{6}$

Haiti underwent a major shift in 1789 . Waves of bloody revolutions in France sent tremors throughout the French colonies. Meanwhile, Haiti's already unstable society fractured along class, racial, political, religious, and occupational fault lines. The Declaration of the Rights of Man and of the Citizen roused free black and mixed-race Haitians to assert claims of equality with French citizens, regardless of race. ${ }^{7}$ Although these two groups represented a small fraction of the Haitian population, they owned much of the land and most of the slaves. Then in 1791, when rumors circulated that French King Louis XVI wanted to free slaves, a priestess (mambo) led a ceremony in which she called on enslaved Haitians to revolt, claiming this mandate came from Ogun, the Voodoo god of war. She stated that Ogun "orders revenge! He will direct our hands; he will aid us." Then she added that slaves should "listen to the voice of liberty that speaks in the heart of all of us."

In recent years, scholars have noted a connection between practicing religious beliefs and fomenting

\footnotetext{
${ }^{6}$ Anthony B. Pinn, Varieties of African American Religious Experience: Toward a Comparative Black Theology, zoth anniv. ed. (Minneapolis, MN: Fortress Press, 2017), 3-10; and Claudine Michel, "Of Worlds Seen and Unseen: The Educational Character of Haitian Vodou," Comparative Education Review 40, no. 3 (August 1996): 280-94, https://doi.org /10.1086/447386.

7 Throughout the periods of Haiti's history discussed in this article, individuals with one white parent and one black parent were referred to as mulattres or mulattos, and their social status often was determined by such racial castes/categories. For the remainder of this article, the term mixed-race will be used in place of the term mulatto except in directly quoted material.

${ }^{8}$ Laurent Dubois, Avengers of the New World: The Story of the Haitian Revolution (Cambridge, MA: Belknap Press, Harvard University Press, 2004), as cited in Girard, Haiti, 40 .
}

political action. Religion professor Leslie G. Desmangles observes that Voodoo's "rituals provided the spirit of kinship that fueled the slaves' revolts against their masters." Elsewhere, black studies scholar Claudine Michel argues that Voodoo provided a "unifying force" and a "catalyst for the revolutionary accomplishments for which Haiti is known." ${ }^{10}$ Those beliefs translated into a violent insurgency against the French colonial government. Haitian slaves, according to historian Philippe Girard, joined the revolt and fought the French by "relying on the support of sympathetic locals; making the best of a rugged terrain; and refusing pitched battles with a superior enemy." Girard then avows that "centuries before Che Guevara and Ho Chi Minh, Haiti's black rebels had perfected all the principles of modern guerrilla warfare." ${ }^{\prime 1}$

The fighting lasted until 1803 when the Haitians finally defeated French colonial forces. In 1804, the Haitians declared their independence from France, claimed to be the sovereign Empire of Haiti, and thus followed the United States of America as only the second colony in the Western Hemisphere to throw off European colonial rule. Despite high hopes for freedom, the two centuries since Haiti won its independence never saw real democracy or equality develop. Instead, for the next century, revolutions and anarchy reigned when despots did not.

\section{American Interventions in Latin America, 1898-1935, and Haiti, 1915-34}

A victory against Spain in 1898 enabled the United States to absorb the Spanish Empire's territories, thereby asserting hegemony over nations in Latin

\footnotetext{
${ }^{9}$ Leslie G. Desmangles, The Faces of the Gods: Vodou and Roman Catholicism in Haiti (Chapel Hill: University of North Carolina Press, 1992), 6.

${ }^{10}$ Claudine Michel, "Vodou in Haiti: Way of Life and Mode of Survival," in Claudine Michel and Patrick Bellegarde-Smith, eds., Invisible Powers: Vodou in Haitian Life and Culture (New York: Palgrave Macmillan, 2006), 32. See also Alfred Métraux, Voodoo in Haiti, trans. Hugo Charteris (New York: Schocken Books, 1972), 41, as cited in Abel A. Alves, "Voodoo Syncretism in Haiti and New Orleans" (class presentation, History 468, Witcheraft, Magic, and Science in the Early Modern World, 1492-1859, Ball State University, April 2008).

${ }^{11}$ Girard, Haiti, 28-29.
} 
America and the Caribbean. Suddenly, the United States joined the European nations as one of the great powers with colonies around the globe. Closer to home, Americans claimed the role of protector of the Western Hemisphere when President Theodore Roosevelt articulated an updated corollary to the Monroe Doctrine of 1823 . This term doctrine is not used in a military sense, but rather denotes a set of diplomatic policies. President James Monroe's original doctrine forbade Europeans from colonizing or interfering in the Western Hemisphere because he claimed this region as part of the American sphere of influence. Nearly a century later, Roosevelt's Corollary in 1904 gave the United States the auspices to expand commercial interests in Latin America and protect those interests by force against indigenous or European threats. As Roosevelt's successor from 1909 to 1913, President William Howard Taft continued the Corollary in Latin America and gave it the moniker: "Dollar Diplomacy." ${ }^{12}$

Next came President Woodrow Wilson, who stated in 1913, "I am going to teach the South American republics to elect good men!" Although he ostensibly referred to Mexico, the statement applied throughout Latin America and the Caribbean. ${ }^{13}$ Always the idealist and progressive, Wilson believed that the United States could export democracy, freedom, and civilization to other nations overseas. If taught American virtues, then the people of Latin America would embrace American institutions. Prosperity for the indigenous populations and American businesses would follow as byproducts of Wilson's decisions. If necessary, the use of military force could be one means to attain Wilson's progressive vision in Latin America. During the years, several scholars, including the eminent histo-

\footnotetext{
${ }^{12}$ For a recent book that not only analyzes Dollar Diplomacy but also serves as a model for blending military and cultural history, see Ellen D. Tillman, Dollar Diplomacy by Force: Nation-Building and Resistance in the Dominican Republic (Chapel Hill: University of North Carolina Press, 2016), 1-10, 53-77.

${ }^{13}$ Woodrow Wilson, statement to British envoy William Tyrrell, ca. November 1913, as cited in Benjamin T. Harrison, "Woodrow Wilson and Nicaragua," Caribbean Quarterly 51, no. 1 (March 2005): 26, https://doi .org/10.108o/ooo86495.2005.11672257.
}

rian William E. Leuchtenburg, equated progressivism with imperialism. Leuchtenburg argued that "imperialism and progressivism flourished together because they were both expressions of the same philosophy of government, a tendency to judge any action not by the means employed but by the results achieved ... and almost religious faith in the democratic mission of America." ${ }^{14}$

Apart from systemic political unrest and economic instability in Latin America, the strategic imperatives play significant roles in the American inventions. After decades of seemingly endless construction efforts, the opening of the Panama Canal in August 1914 solidified the strategic American interest of maintaining sea lanes in the Caribbean. In that same month, the outbreak of war in Europe further heightened the geopolitical importance of the region. The United States could not tolerate Europeans extending their conflict into the Western Hemisphere. Haiti's government slipped into debt to the United States, Germany, and other nations, making it more vulnerable to foreign influences. Civil strife was also a constant: six Haitian presidents were overthrown and replaced in rapid succession between 1911 and 1915. When these factors are contextualized, Democratic and Republican American presidents alike felt justified in sending U.S. Marines to the region. ${ }^{15}$

President Woodrow Wilson recognized that a stable Haiti helped ensure a peaceful Caribbean. Wilson remarked to his acting secretary of state Robert Lansing that "there is nothing to do but take the bull by

\footnotetext{
${ }^{14}$ William E. Leuchtenburg, "Progressivism and Imperialism: The Progressive Movement and American Foreign Policy, 1898-1916," Journal of American History 39, no. 3 (December 1952): 500, https://doi.org /10.2307/1895006. For other historians with varying ideologies but similar conclusions, see Walter LaFeber, Inevitable Revolutions: The United States in Central America, 2d ed. (New York: W. W. Norton, 1993), 3178; Alan McPherson, The Invaded: How Latin Americans and Their Allies Fought and Ended U.S. Occupations (New York: Oxford University Press, 2014), 1-9; Pamphile, Contrary Destinies, 17-18; and Matthew S. Muehlbauer and David J. Ulbrich, Ways of War: American Military History from the Colonial Era to the Twenty-First Century, 2d ed. (New York: Routledge, 2017), 267-75, 319-21.

${ }^{15}$ See LaFeber, Inevitable Revolutions; and McPherson, The Invaded.
} 
the horns and restore order. ${ }^{{ }^{16}}$ Wilson ordered $340 \mathrm{Ma}-$ rines and sailors to land in Port-au-Prince and restore order on 28 July 1915 . The term invade more accurately described their arrival. Several thousand Marines did tours in Haiti during the next two decades. Making the connections between order and peace pointed to the bigger American objective: establishing hegemony in the region. The choice of terms and tones pointed to an imperial effort. Indeed, the Marines can be seen as agents of imperialism. ${ }^{17}$

In his role as the first American naval commanding officer, Rear Admiral William B. Caperton declared martial law, disbanded the Haitian Army, and took control of Haiti's customs houses. The latter move gave the United States control of the nation's revenue. ${ }^{18}$ Looking back from 1934 to his occupation duties, Marine veteran Captain John H. Craige wrote candidly, if not also cynically, "I blush at the transparent maneuvers to which we resorted to make it appear that the Haitians were accomplishing their own regeneration in accordance with democratic principles as understood in the United States." ${ }^{\prime 9}$

The Haitians found themselves compelled to accept an unpopular president named Philippe Sudré Dartiguenave, yet it was clear to the people that the Marines ran the government. The Haitians found the corvée system to be the most vexing American policy. This system mandated that peasants paid taxes or worked in kind to maintain roadways. Impoverished laborers could not pay, so they worked-sometimes compelled by violence or threats from the Marines. The resulting problems exacerbated the suffering of Haitians living at subsistence levels. Indeed, for some Haitians, the Marine occupation represented a return to race-based slavery. The corvée system likely aggra-

\footnotetext{
${ }^{16}$ Cited in Max Boot, The Savage Wars of Peace: Small Wars and the Rise of American Power (New York: Basic Books, 2002), 161.

${ }^{17}$ For more analysis, see D'Arcy Morgan Brissman, "Interpreting American Hegemony: Civil Military Relations during the U.S. Marine Corps' Occupation of Haiti, 1915-1934" (PhD diss., Duke University, 2001).

${ }^{18}$ See Edward Latimer Beach, "Admiral Caperton in Haiti," [ca. 1915], 1-5, Naval History and Heritage Command, accessed 13 May 2019; and Boot, The Savage Wars of Peace, 159-66.

${ }^{19}$ John Houston Craige, Cannibal Cousins (New York: Minton, Balch, 1934), 6o, as cited in Boot, The Savage Wars of Peace, 167.
}

vated the tense situation in Haiti and fed the insurgent violence against the Marines and their puppet government. ${ }^{20}$

In practice, neither the Americans nor their client rulers exerted power in the countryside as long as bandits, mercenaries, and revolutionaries (known as cacos) obstructed attempts by the Haitian government and Marines to establish law and order. As many as 15,000 cacos achieved some success as insurgents when led by charismatic leaders like Charlemagne $\mathrm{M}$. Péralte in 1918. He used guerrilla tactics to ambush gendarme (police) units in rural areas or conducted hit-and-run attacks against small outposts. The cacos then melted back into the civilian populace. They also intimidated and terrorized the peasants living there who might assist the Americans. Combating these insurgents proved to be no simple task. In one key measure in 1916, the Marines formed Gendarmerie d'Haiti, a constabulary force with mostly Marine officers and Haitian enlisted personnel. Within their areas of operations, the Marine officers controlled military, police, and judicial actions. The cacos's insurgency finally ended after Marines killed Péralte in 1919. ${ }^{21}$

Haiti achieved relative stability in 1922 under the government of American-backed president Louis Borno, but the real power lay in the hands of John H. Russell, a Marine Corps brigadier general and the American high commissioner with the rank of ambassador extraordinary. His eight-year tenure until 1930 provided some continuity in Haiti during this period. The number of hospitals and other public buildings multiplied. Russell's initiatives made drinking water safer and improved sanitary conditions in Haitian cities. Infrastructure made marked gains, including the construction of $1,609 \mathrm{~km}$ of new roads and some 200 new bridges. Improvements to harbor facilities

\footnotetext{
${ }^{20}$ Dalleo, American Imperialism's Undead, 10-13; and Renda, Taking Haiti, 10-11, 53, 139-49. The author is grateful to the anonymous peer reviewer for offering key clarifications in this paragraph.

${ }^{21}$ Girard, Haiti, 85-88; Hans Schmidt, The United States Occupation of Haiti, 1915-1934 (New Brunswick, NJ: Rutgers University Press, 1995), 85-90; and Alan McPherson, A Short History of U.S. Interventions in Latin America and the Caribbean (Malden, MA: John Wiley and Sons, 2016), 78-81, 102-5.
} 


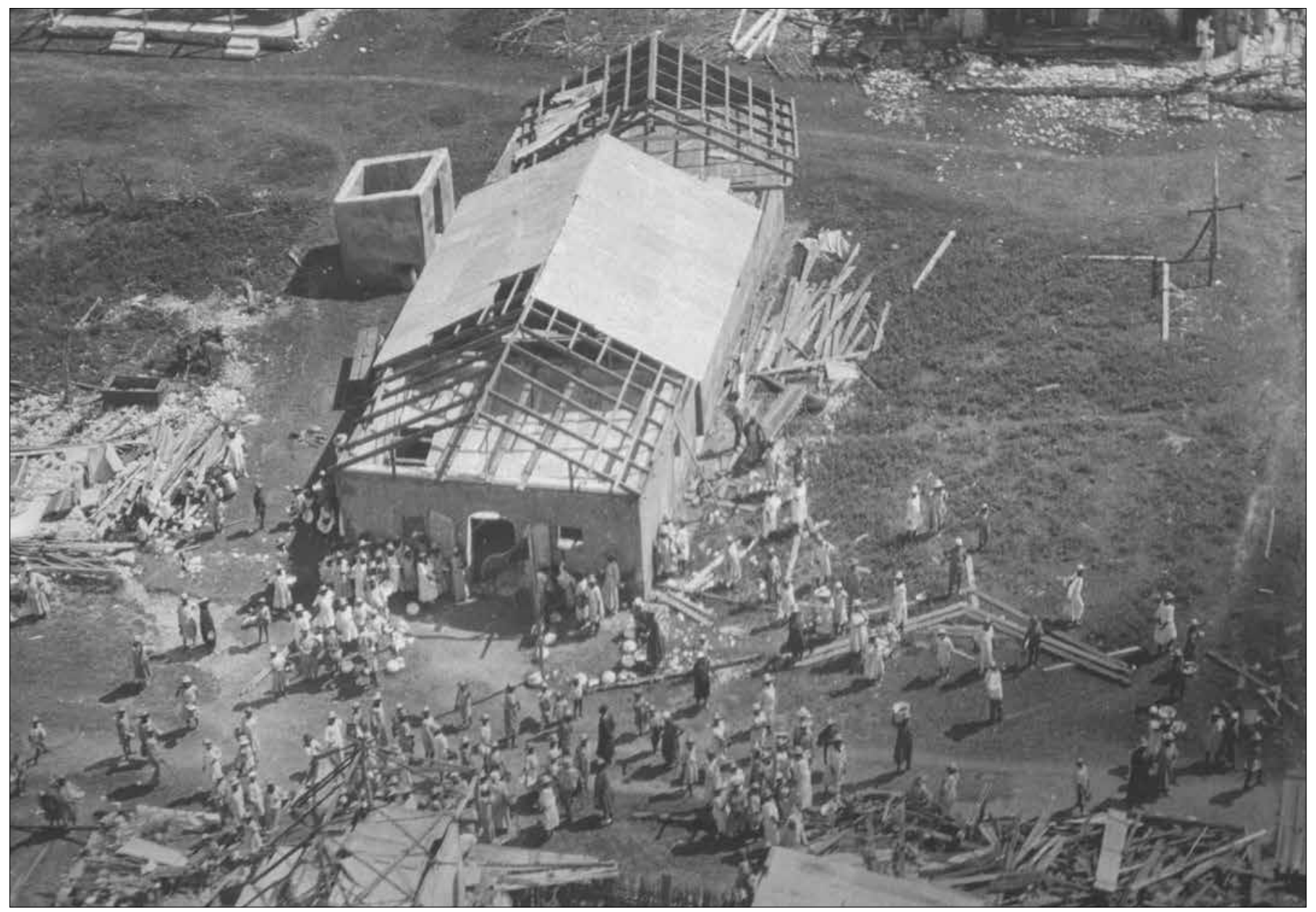

Official U.S. Marine Corps photo, Historical Reference Branch, Marine Corps History Division The Gendarmerie d'Haiti (later Garde d'Haiti) headquarters at Saint-Louis-du-Sud, Haiti, after a hurricane, August 1928.

helped spur Haiti's economic growth, including increasing exports of sugar, cotton, and coffee. However, the labor came from peasants working without pay in the corvée system, and most of the new revenue funded Haiti's national debt or covered costs of the Marine occupation. Additionally, Russell's attempts to establish democratic institutions such as free elections failed to live up to idealized American expectations. ${ }^{22}$

The Marine occupation shifted in mission after

\footnotetext{
22. Pamphile, Contrary Destinies, 28-34. For extensive commentary by a Marine serving in Haiti during the 1920s, see Merwin Silverthorn, interview with Benis Frank, 28 February 1969, transcript (Oral History Section, Marine Corps History Division, Quantico, VA), 138-76, hereafter Silverthorn oral history interview transcript.
}

1929 because falling prices and increasing taxation caused an economic downturn that led to strikes among Haitian workers and violence in the streets. One incident in particular became the symbol of Marine failures. In December 1929, while patrolling the coastal city of Aux Cayes, a small detachment of Marines encountered several hundred Haitian rioters who surrounded and pelted them with rocks. The Marines reacted and fired into the crowd, killing or wounding several dozen Haitians. ${ }^{23}$

In the wake of this tragedy known as the Aux Cayes Massacre, President Herbert Hoover ordered an

${ }^{23}$ Alan McPherson, "The Irony of Legal Pluralism in U.S. Occupations," American Historical Review 117, no. 4 (October 2012): 116o, https://doi .org/10.1093/ahr/117.4.1149. 


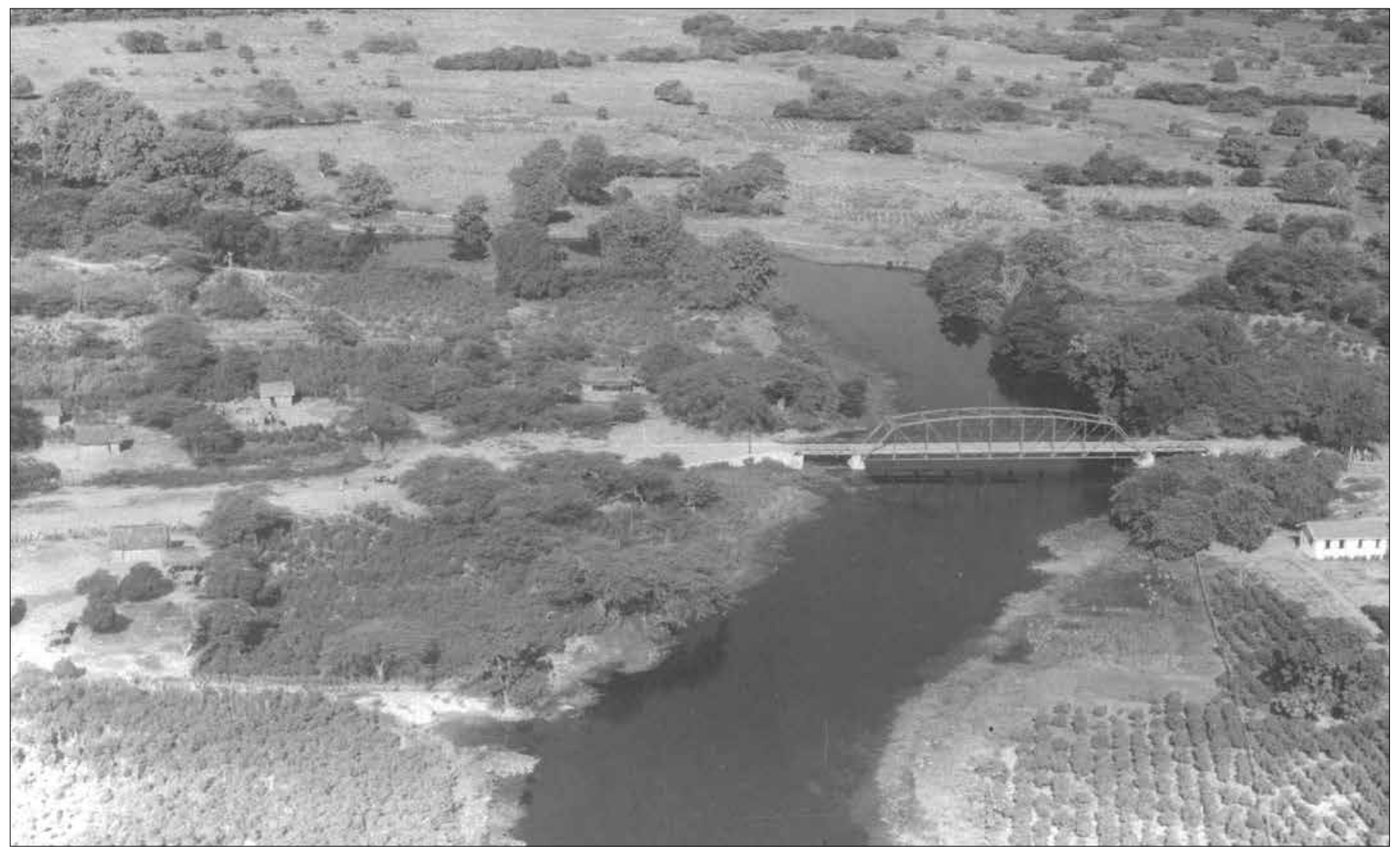

Official U.S. Marine Corps photo 51627, by 1stLt L. N. Bertol, Historical Reference Branch, Marine Corps History Division Haiti, October 1933. Iron bridge across the LaQuinte River, about $3 \mathrm{~km}$ from the town of Gonaives, Haiti, one of the many bridges constructed in Haiti with an assist by U.S. Marine Corps forces and the Marine-trained Garde d'Haiti.

investigation of the incident and the Marine occupation as a whole. The findings recommended that Marines leave Haiti. Consequently, Hoover began shifting away from the interventionism of Dollar Diplomacy toward a new Good Neighbor foreign policy. As the purportedly benevolent neighbor to the north, Americans hoped to create reciprocal commercial and political relationships with the peoples of Latin America. Finally, after taking office in 1933, President Franklin D. Roosevelt ordered the Marines to withdraw from Nicaragua that same year and from Haiti in $1934{ }^{24}$

\footnotetext{
${ }^{24}$ For recent scholarship, see McPherson, A Short History of U.S. Interventions in Latin America and the Caribbean, 124-27; and Girard, Haiti, 94-97. For an older, yet still relevant and balanced, study, see Bickel, Mars Learning, 71-105; and for an explicit neoconservative and American Exceptionalist interpretation, see Boot, The Savage Wars of Peace, 156-82.
}

\section{Haiti's Social Structure and Voodoo Practices}

When the Marines first landed in Haiti in 1915, they found race-based and religious caste systems. The wealthiest 10 percent of Haiti's population oppressed the remaining people. The ruling elite minority was comprised of mixed-race Haitians who spoke French, professed Catholicism, lived in urban areas, and found work in the government or with banks or corporations. Many of them owed their status directly or indirectly to American commercial activities. This elite class tended to ignore or antagonize their fellow Haitians who believed in Voodoo. Among the 90 percent, the impoverished and illiterate Haitian peasant majority, known as noirs, were of purer African ancestry. They spoke Creole, prac- 
ticed Voodoo, and survived as subsistence farmers. ${ }^{25}$

As Marines spent more time in Haiti, they came to dislike the Haitian elite. Some Marines sympathized with the poor Haitian peasants in rural areas, Voodoo practices and racial prejudice notwithstanding. In a report from the early 1930s, one Marine remarked

No matter what crimes [Marines] might count against the better class of Haitian (I refer to the peasants, those without benefit of education) such crimes could not conceivably equal in effect and in their atrocious nature the crimes that have been committed against [the peasants] by the lower class-the professional Haitian politician. ${ }^{26}$

The sarcastic term lower class referenced mixedrace politicians. Decades later in 1969 after he retired, Merwin H. Silverthorn recalled his service as a captain in the 1st Marine Regiment, having briefly served as the unit's commander on two occasions in $1926 .{ }^{27}$ In his oral history interview, he recalled the same twoclass system in Haiti.

The peasants were hard-working people. They would till plots of ground

\footnotetext{
25 "Haiti-Reports and Inquiries Regarding Conditions and Conduct of Marines," report by H. S. Knapp, 14 October 1920, Haiti-History file, Historical Reference Branch, Marine Corps History Division; BGen John H. Russell, "The Development of Haiti during the Last Fiscal Year," Marine Corps Gazette 15, no. 2 (June 1930): 83-85; Gen A. A. Vandegrift as told by Robert B. Asprey, Once a Marine: The Memoirs of General A. A. Vandegrift (New York: Norton, 1964), 57; McCrocklin, Garde d'Haiti, 139; Millett, Semper Fidelis, 178-79; Heinl and Heinl, Written in Blood, 2-5; Patrick Bellegarde-Smith, "Resisting Freedom: Cultural Factors in Democracy-The Case of Haiti," in Michel and Bellgarde-Smith, Invisible Powers, 107; Desmangles, The Faces of the Gods, 2-3, 8-10, 50; and Renda, Taking Haiti, 19, 274-75. For more analysis of the Haitian elite, see Magdaline W. Shannon, Jean Price-Mars, the Haitian Elite, and the American Occupation, 1915-1935 (New York: St. Martin's, 1996), https://doi.org/10.1007/978-1 -349-24964-o.

26 "Haiti-History," report by an anonymous author, [ca. 1930], Haiti file, Historical Reference Branch, Marine Corps History Division. For similarly disdainful attitudes among Marines regarding Haitian elite, see also John H. Russell, "A Laboratory of Government," Russell Papers, box 3, folder 6, Archives Branch, Marine Corps History Division; Millett, Semper Fidelis, 187; and Schmidt, Maverick Marine, 88-89.

${ }^{27}$ Danny J. Crawford, et al., The 1st Marine Division and Its Regiments (Washington, DC: History and Museums Division, Headquarters Marine Corps, 1999), 3-24.
}

on the side of the mountain or along a riverbed somewhere with primitive tools, transport them long distances to market. .. They lived on very meager income, but they were very solid, reliable people. They were pleasant to be with. ${ }^{28}$

Silverthorn later criticized the wealthy Haitian as an "educated man" who was a "schemer" and "lives off the product of his less fortunate people."29 Even so, most American Marines deployed to Haiti between 1915 and 1934 were firmly instilled with Protestant, Caucasian, and Anglo-Saxon mores. These factors informed their attitudes about the Haitians.

Because some of the Marine officers had Protestant upbringings, they also conflated Voodooism with Catholicism as twin blights on Haitian culture, both in need of reform. ${ }^{30}$ Voodoo in fact blends West African religious traditions with Catholicism. In the Haitian peasant's eyes, lighting candles and the scents and bells used during Catholic mass resembled Voodoo ritual. They saw some similarities between venerated Catholic figures such as the Virgin Mary and Saint George with Voodoo figures such as Ezili, the loa of maternal and physical love, and Ogun, the loa of war. This fusion of the two religions is called syncretism by scholars. The Haitian peasants were far more likely to combine Voodooism with Catholicism than to accept the Protestant Christianity espoused by most American Marines. ${ }^{3}$

Racial attitudes cannot be ignored. Back in the United States, Jim Crow laws still repressed African Americans, and lynchings of blacks occurred in rural areas. Racist sentiments ran up and down the ranks

\footnotetext{
${ }^{28}$ Silverthorn, oral history interview transcript, 153 .

${ }^{29}$ Silverthorn, oral history interview transcript, 165.

${ }^{3}$ See also Carl Kelsey, Address on the Republic of Haiti Today. Delivered before the Society of Sons of the Revolution on April 29, 1922 (Washington, DC: Society of the Sons of the Revolution, 1922), 23; Michel, "Voodoo in Haiti," 27; Desmangles, The Faces of the Gods, 1-3; and Renda, Taking Haiti, 45-52.

${ }^{31}$ Desmangles, The Faces of the Gods, 5-10, 27, 50, 132, 177; and Girard, Haiti, 30-31.
} 


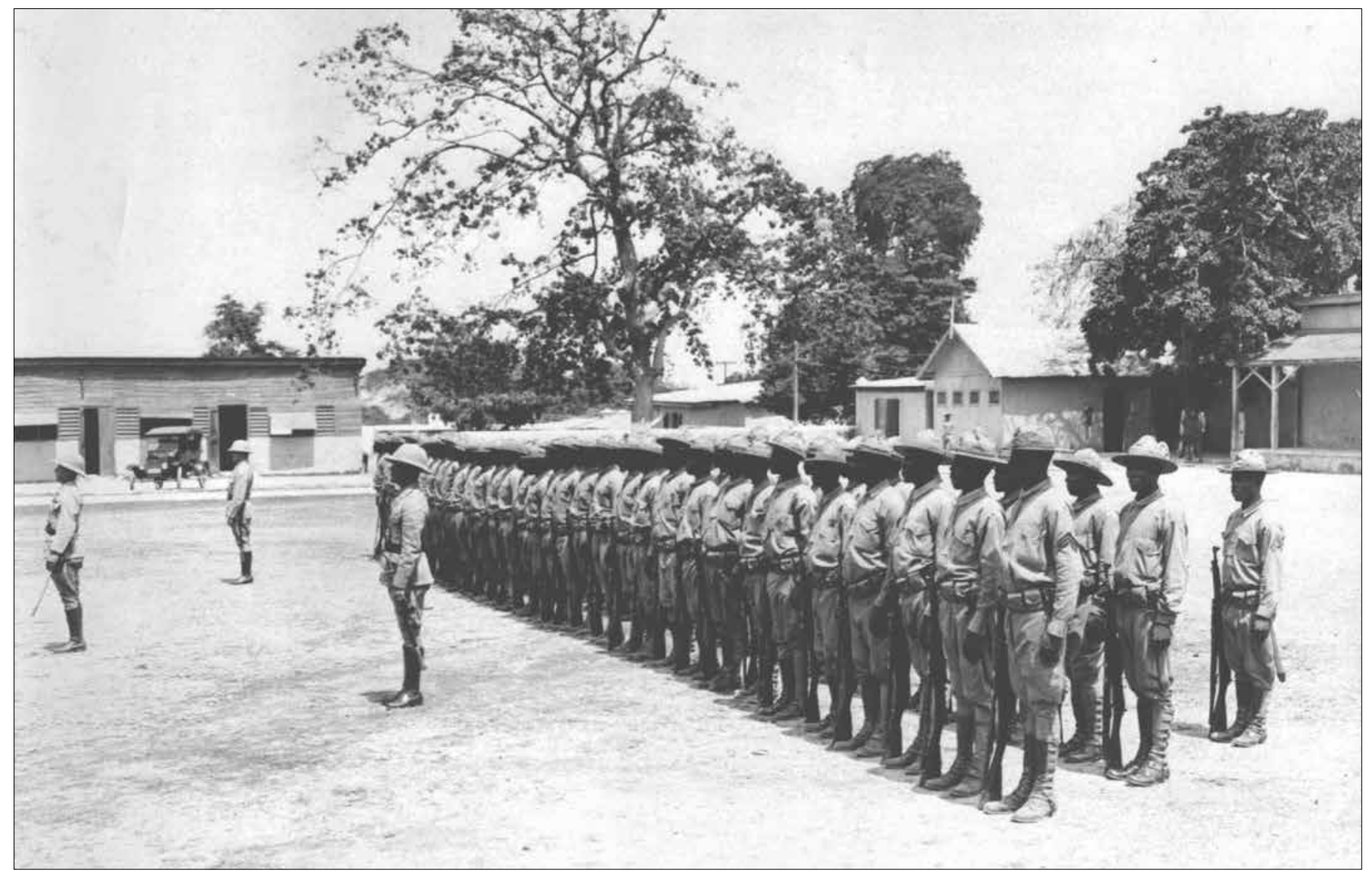

Official U.S. Marine Corps photo, Historical Reference Branch, Marine Corps History Division Trained and commanded by U.S. Marine Corps officers and noncommissioned officers, this is a typical company of the Gendarmerie d'Haiti (later Garde d'Haiti) that played an important part in bringing law and order to the Republic of Haiti, April 1927.

of the Marine Corps. ${ }^{32}$ In the 1920 , when one enlisted Marine learned that he would be stationed in Haiti, he reacted with disgust in a letter that he did not believe "any white man should be killed to save a few ignorant $\mathrm{n}-\mathrm{s}$, without whom the world would be much better off." ${ }^{33}$ Among the officers, approximately

\footnotetext{
${ }^{32}$ For an example of disturbing white supremacist biases regarding Haiti, see Stuart Omer Landry, The Cult of Equality: A Study of the Race Problem, 2d ed. (New Orleans, LA: Pelican, 1945), 108-15, 136. For a more critical analysis of race, American foreign policy, and Haiti, see Michael H. Hunt, Ideology and U.S. Foreign Policy (New Haven, CT: Yale University Press, 1988), 58-68, 99-103, 126-31; and Pamphile, Contrary Destines, 32-34. For the cultural contexts of racial theories and racism in the early twentieth century, see Wintermute and Ulbrich, Race and Gender in Modern Western Warfare, 3-12, 45-49, 80-89; and C. Loring Brace, "Race" Is a Four-Lettered Word: The Genesis of the Concept (New York: Oxford University Press, 2005), 5-42.

33 Emil Porter, letter, March 1928, Emil Porter Personal Paper Collection, Robert E. and Jean R. Mahn Center for Archives and Special Collections, Ohio University, Athens, $\mathrm{OH}$.
}

50 percent of the white Marine officers hailed from former slave-holding states, whereas the white male population of those states amounted to 15 percent of their demographic in the United States in the 1920s. ${ }^{34}$ The prejudice was not limited to those officers from the southern states, but also extended to northerners. Pennsylvanian Brigadier General Smedley D. Butler commented in the 1920 s on commanding the Garde d'Haiti, "I am reduced to a very humiliating position" as the "chief of a $n-r$ police force." 35 Later, after he

\footnotetext{
${ }^{34}$ See Heather Pace Marshall, "Crucible of Colonial Service: The Warrior Brotherhood and the Mythos of the Modern Marine Corps, 1898-1934" (master's thesis, University of Hawaii, 2003); and Schmidt, Occupation of Haiti, 142-44.

35 Cited in Robert L. Scheina, Latin America's Wars: The Age of the Professional Soldier, 1900-2001, vol. 2 (Dulles, VA: Brassey's, 2003), 47. For similar quotes by Butler and other Marines, see Schmidt, Maverick Marine, $75-76,82-84$.
} 


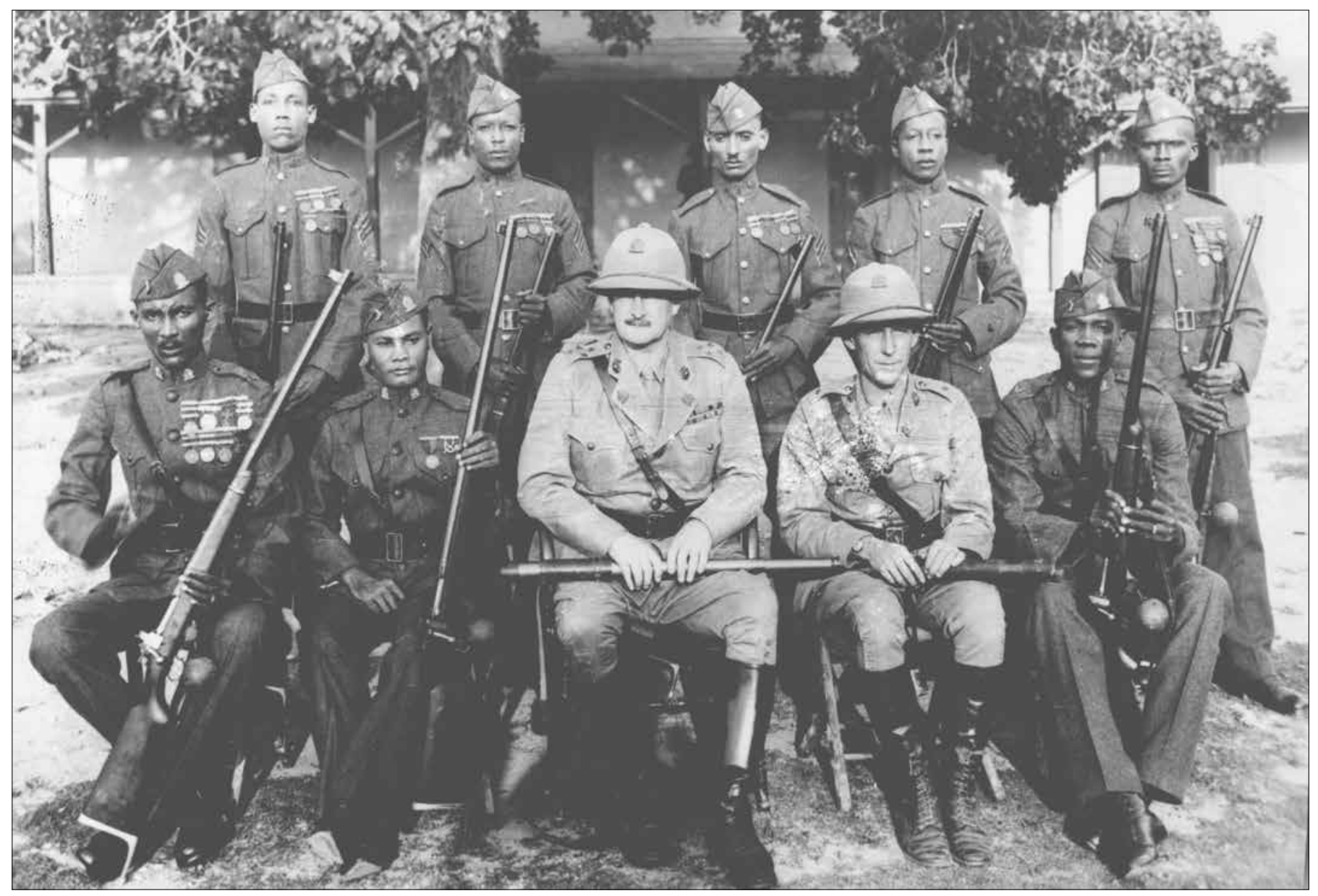

Riflemen of the Haitian gendarmerie.

Official U.S. Marine Corps photo 3167, Historical Reference Branch, Marine Corps History Division

took command of the gendarmerie, Butler called the Haitians "chocolate soldiers." This label may not have matched the vitriol of Butler's earlier comments, but it was no less prejudiced. When enlisted Marines revealed their attitudes in personal letters, they might be limited only to themselves and the recipient of their letters. However, a senior leader expressing views such as Butler's indicated a very real possibility that the organizational culture was infected with those attitudes. ${ }^{36}$

In similar ways, American and Marine prejudic-

${ }^{36}$ For an example in the U.S. Navy, see Harry Knapp to Secretary of the Navy, 13 January 1921, box 632, RG 45, WA-7, NARA, as cited in Pamphile, Contrary Destinies, 31. For more on American attitudes during occupation of the Dominican Republic, see Tillman, Dollar Diplomacy by Force, 80-81, 130 . es depicted Voodoo and its practitioners in pejorative ways. Some Haitians practiced polygamy, promiscuity, or cannibalism, all of which the Marines found to be immoral and often illegal. It is easy to see why Marines were inclined to equate the religion with Christian notions of witcheraft and identify its Haitian followers as superstitious peasants at best or self-professed witch doctors or sorcerers at worst.

An incident in 1928 illustrated how Haitians might take Voodoo's medical treatments for granted, while Marines took a more skeptical view. A memorandum related that a Haitian man named Emmanuel Philinmon complained that someone or something mysteriously hit his stomach despite claiming no one entered his room. Then, according to his relatives, he "became insane and incoherent" two days later, and 


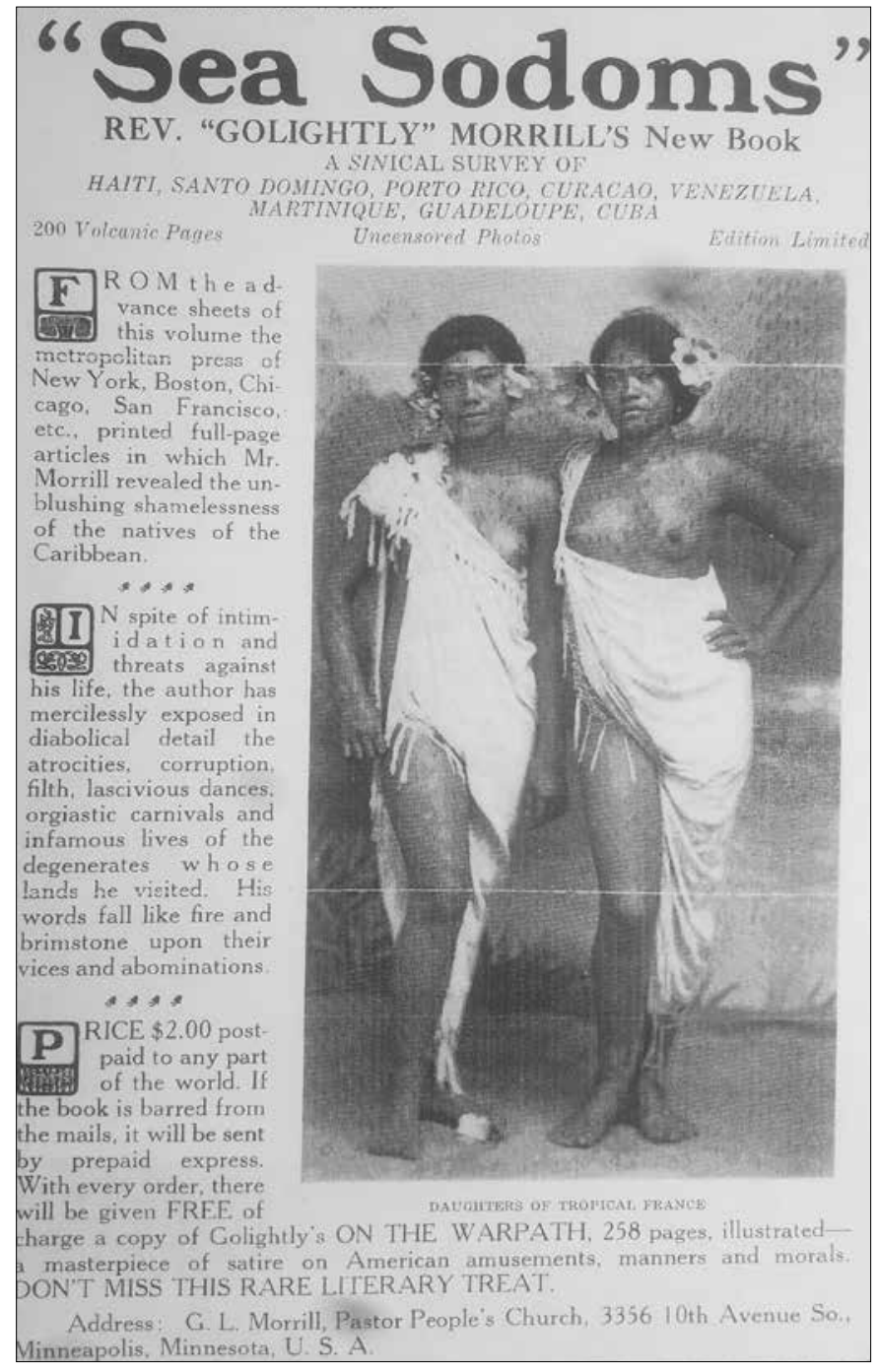

John H. Russell Papers, box 2, folder 18, Archives Branch, Marine Corps History Division Advertisement for the Reverend G. L. Morrill's provocative book published in the United States in 1921. The advertisement played on and contributed to Americans' racial, sexual, and religious assumptions.

they stated that Philinmon "was possessed of the devil." They claimed that he spoke these words: "I do not want to leave Philinmon. I was ordered and sent to take you with me ... and I tell you that I am a relative of Lucifer." The relatives then treated him with "native leaves and roots only in the form of liquid." When the madness gripped Philinmon again, they bound his hands to prevent injury. After about 10 days, he died. His family did not ask for conventional medical treatment or medicines. Thus, the cause of death could not be confirmed. The Marine writing the report conclud- ed, "I myself belief that [Philinmon's] mental affliction is probably due to the fever and also this history of the devil is due to the ignorance of these people." ${ }^{37}$ The Marine's investigation uncovered other details that painted a more disturbing picture of Philinmon's death.

\section{Marine Attempts to "Stamp Out" Voodoo}

The Marines tried to "tame" Haiti, to use the words of historian Mary A. Renda in 2001. Uplifting the "inferior" Haitian people involved what could be considered to be an Americanized process of the French colonial term mission civilisatrice. Renda also finds that the Marines attempted to "modernize and rationalize Haitian society" and thus exhibited "paternalism." ${ }^{8}$ Looking back from the 1960 s to his time as a junior Marine officer serving in Haiti, retired General Alexander A. Vandegrift remarked, "In a sense our task formed a civil counterpart to the work of Christian missionaries who were devoting their lives to these people."39 Renda's observation and Vandegrift's reflection were consistent with the progressive goals that President Wilson espoused when he ordered the Marines into Haiti in 1915.

Like race and caste, Voodooism emerged as a major obstacle to the Marines' modernization and rationalization of Haiti. The religious practices served as modes of disruption and means of resistance that undermined the Marines' efforts to install stability, as evinced in a Marine Corps report on illegal Voodoo rituals in Haiti, which noted that "arrests have been made for superstitious practices, which have created disorder, fear and crime since March 1924." The words disorder, fear, and crime must be emphasized because

\footnotetext{
37 The District Commander, Cerca La Source, memorandum for the Department Commander, Subject: Report on Death of Emmanuel Philinmon, 25 July 1928, Seldon Kennedy file no. 3248, Historical Reference Branch, Marine Corps History Division.

${ }^{38}$ Renda, Taking Haiti, 46, 45-52, 114-15, 212, 238. See also Desmangles, The Faces of the Gods, 31-37, 177; and Hunt, Ideology and U.S. Foreign Policy, 128-32. For a military analysis, see David Keithly and Paul Melshen, "Past as Prologue: USMC Small War Doctrine," Small Wars and Insurgencies 8, no. 2 (Autumn 1997): 93-96, https://doi.org/10.108o/09592319708423175. 39 Vandegrift, Once a Marine, 57-58. See also Schmidt, Maverick Marine, 91.
} 
they represented everything that the Marines hoped to avoid in Haiti. ${ }^{40}$

Article 409 in Haiti's Code Penal mandated that "makers of ouangas [talisman], practitioners of Voodoo, macandalisme" and "all dances and other practices calculated to foster fetishism and superstition shall be deemed witcheraft and punished accordingly." ${ }^{21}$ At any given time, Marines banned Voodoo ceremonies, raided places of worships (called hounforts), or confiscated drums and other religious objects utilized in rituals. ${ }^{42}$ In the Dominican Republic as in Haiti, the Marine-controlled governments banned Voodoo in what, according to Latin American military historian Ellen Tillman, "was a direct attack on integral cultural practice." ${ }^{43}$

The Marines also found a corrupt Haitian legal system that needed reform. For the Marines, herein lay one of the most effective ways to achieve American goals. Aside from being susceptible to bribery, the Haitian courts could be swayed by Voodooism. Haitian juries, for example, acquitted their countrymen of murder charges if the victims were supposed werewolves (loup-garou), dangerous or evil beings in Voodoo. ${ }^{44}$

To eliminate what the Marines saw as injustices, they established provost courts under the auspices of declaring martial law in 1915. Composed of one or three Marines serving as judges, these military tribu-

\footnotetext{
${ }^{40}$ C. H. Gray, memo for Department Commander, Department of the North, 17 October 1927, "Voodoo and Witcheraft Cases (14 September 1927 to 19 December 1930)," box 20, Records of the Gendarmerie d'Haiti, RG 127, A1, entry 21, NARA, hereafter Gray memo. Special thanks should go to Mr. Trevor Plante, an archivist in Old Military Records at the National Archives in Washington, DC, for helping the author to locate this file.

${ }^{41}$ As cited in Heinl and Heinl, Written in Blood, 484n59. The term macandalisme came from the name of an Arabic-speaking slave, Macandal, from West Africa who was burned at the stake after being convicted of attempting to poison whites and spreading that knowledge.

${ }^{42}$ Renda, Taking Haiti, 212-13.

${ }^{43}$ Tillman, Dollar Diplomacy by Force, 110.

${ }^{44}$ For particular cases whether accused murders were released because they had killed supposed werewolves or people similar possessed by evil spirits, see Harry Watkins, memo for Department Commander, Department of the North, 14 September 1927; and Gray memo. See also McCrocklin, Garde d'Haiti, 131-32; and Heinl and Heinl, Written in Blood, 417,456
}

nals heard cases involving the most violent Haitian offenders. ${ }^{45}$ Over time, fewer and fewer provost courts were called and, by 1927, none at all. At the behest of his superiors in Washington, High Commissioner John Russell increasingly turned over judicial functions to the Haitians, so long as they dispensed justice fairly. The Marines nevertheless kept records of Voodoo cases to ensure that justice was served. ${ }^{46}$

These legal reports referenced two types of prosecutions against Voodoo-related criminal offenses. The first type entailed prosecuting Haitians for Voodoo practices and rituals. Such offenses could be relatively benign in that no one was necessarily killed or seriously injured. In cases following arrests "made for superstitious practices which have created disorder, fear and crime," Haitians found guilty received fines and jail sentences, but these penalties were not so severe because some offenses were considered misdemeanors in nature. ${ }^{47}$ The crimes always disrupted stability because the laws prohibiting Voodoo required enforcement, or order would dissolve into anarchy. A sampling of the arrests made for the religious practices and sentences imposed during the late 1920 can be seen in the following report.

Dec. 13, 1926-

Edouard Lazarre [and others] were arrested for a Vaudou dance. The testimony stated that this dance was made for the Saints. They were each sentenced to serve 4 months in prison and pay a fine of 60 gourdes by the

\footnotetext{
45 General Order No. 6 issued by HQ District Commander, 9 September 1915, and General Order No. 8 issued by District Commander's Office, 14 September 1915, both in "Haiti Occupation 1915-1934 Organization," Historical Reference Branch, Marine Corps History Division; John H. Russell to the U.S. Secretary of State, 1 January 1923, Russell Papers, folder 18, box 2, Archives Branch, Marine Corps History Division; LtCol Charles J. Miller, "Diplomatic Spurs: Our Experiences in Santo Domingo," Marine Corps Gazette 19, no. 3 (August 1935): 41-42; Heinl and Heinl, Written in Blood, 417, 456; Schmidt, United States Occupation of Haiti, 74-75; and Millett, Semper Fidelis, 199, 204.

${ }^{46}$ Heinl and Heinl, Written in Blood, 456-58, 464-67, 501-6; and Millett, Semper Fidelis, 208-10. The acquittals of those Haitians suspected of murdering werewolves is corroborated in McPherson, "The Irony of Legal Pluralism," 1157-59.

${ }^{47}$ Gray memo.
} 


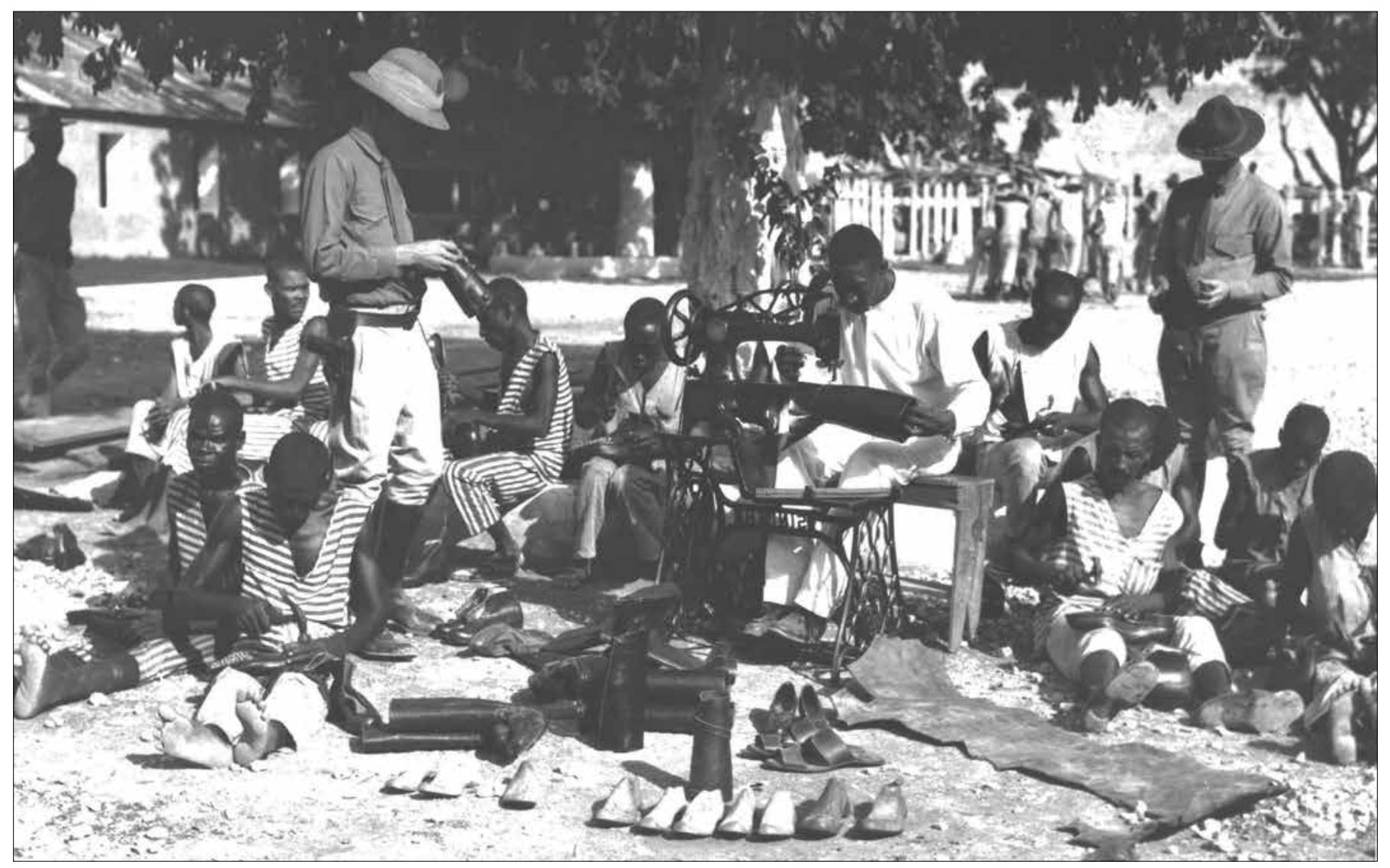

Official U.S. Marine Corps photo 519856, Historical Reference Branch, Marine Corps History Division Haitian prisoners making shoes at the National Penitentiary at Port-au-Prince, Haiti, ca. 1919.

[Haitian Justice of the Peace in Mombin Crochu]..$^{8}$

The testimony cited in the 13 December summary demonstrated, according to the Marines' perspective, how Haitians blended Voodooism and Catholicism. Nevertheless, this allusion to Catholicism did not necessarily equate to sufficient grounds for acquittal by the court as seen several weeks later.

\section{Jan. 11, 1927-}

Eltrevil Saintilmon [and others] were arrested for cooking "Manger pour les Saints". They were each sentenced to serve 3 months in prison and pay a fine

\footnotetext{
${ }^{48}$ Gray memo. Current conversions show that 6o gourdes equal approximately \$.62 (U.S. 2019).
}

of 60 gourdes by the [Haitian Justice of the Peace in Vallieres].49

The criminal act in the 11 January summary entailed leaving food for the Voodoo spirits. It did not matter that the term saints was used by the defendants.

Sometimes the accused would be released by the Haitian courts because their potions had been used to heal sick children.

Jan. 16, 1927-

Charlestin Charles [and others] were arrested for "Ouanga." They were sentenced to serve 3 months in prison and

\footnotetext{
49 Gray memo.
} 
pay a fine of 6o gourdes by [Haitian

Justice of the Peace in Vallieres]..$^{\circ}$

In Voodoo, ouanga were talisman or spells that could be cast to protect oneself and one's family, or they could inflict some harm on people. One example of ouanga is the Voodoo doll..$^{11}$ Some ouangas might be used to ward off zombies (sometimes rendered zambie) or to direct zombies to kill enemies. As far as the Marines were concerned, turning a person into a zombie represented one of most odious of Voodoo practices because, as one scholar observes, a zombie was "a person whose soul has been captured by a sorcerer, leaving the individual without a will of their own." ${ }^{2}$ The Haitians' beliefs made zombification antithetical to the American Marines' sense of individual autonomy and reinforced their assumptions of Haitian superstitions.53 The 16 January 1927 summary was not clear about the purpose of the spell that was cast; however, if found guilty, Haitians so accused of "making ouanga" faced similar fines and prison terms. ${ }^{54}$

The second type of Voodoo prosecution involved criminal activities in which Voodoo was allegedly employed to harm others, either financially or physically. Offenses included extortion, blackmail, assault, and murder. Although the existing archival evidence does not include the final verdicts set down by Haitian courts, the following accusations, testimonies, and reports of these cases illustrated the attitudes among Marines about the illegitimacy of Voodooism as well as the disruption caused when its practices were used as a justification for what the Marines deemed to be criminal activities. 55

In one report to the commandant of the Garde d'Haiti in 1929, the subject read as "Swindling by means of witcheraft." ${ }^{66}$ The complainant, a woman named Vallerie Laville, claimed her family member

\footnotetext{
${ }^{50}$ Gray memo.

${ }^{51}$ Heinl and Heinl, Written in Blood, $784-85$.

${ }^{52}$ Carrol F. Coates, "Vodou in Haitian Literature," in Invisible Powers, 193.

${ }^{53}$ Renda, Taking Haiti, 223-27.

${ }^{54}$ Gray memo.

55 Silverthorn, oral history interview transcript, 160.

${ }^{56}$ C. I. Murray, memo to Commandant of the Garde d'Haiti, 25 January 1929, "Voodoo and Witcheraft Cases," RG 127, A1, entry 21, NARA, 1, hereafter Murray memo.
}

had been victimized to the extent of thousands of dollars by persons who had, by means of drugs, sorcery and certain acts of alleged witchcraft, intimidated [the Laville family] into paying stupendous amounts of money which was in turn to be paid over the certain evil spirits in order to combat other spirits who were supposed to hold the lives of the Laville family in their hands and who lusted for their blood. 57

A four-page statement by Laville was appended that laid out her grievances and demonstrated her desire for justice. Near the end of this report, those accused of extortion and swindling included one woman who, according to the Marines' subsequent investigations, was a "known sorceress and artistic witcheraft expert" who had "many politicians and private citizens under her thumb." ${ }^{8}$ A second alleged accomplice was "noted as a rounder." 59 They were, to use today's terminology, scam artists. No final verdict existed in the archival records. ${ }^{60}$ However, the language herein indicated that the exploitation of Haitian peasants' beliefs fit into Marines' skeptical view of Voodoo's legitimacy as a religion.

Voodoo also played roles in investigations of violent crimes as evinced in an "instance where superstitious practices have led to murder." ${ }^{\text {161 }}$ This quote from the first lines of the Marines' report makes the verdict a foregone conclusion. The report included statements made by the defendant, St-Ilmar Jean, during an interrogation about her role in her mother's death

\footnotetext{
${ }^{57}$ Murray memo, 1.

${ }^{58}$ Murray memo, 5 .

${ }^{59}$ Murray memo, 5 .

${ }^{60}$ Sometimes criminal cases were not pursued because of a lack of evidence, as seen in these two documents: District Commander, memo for the Department Commander, District of the Center, 25 July 1928; and Department Commander, District of the Center, memo for the Chief of the Gendarmerie, 27 July 1928, both in Sheldon Kennedy Personal Papers Collection, file 3248, Archives Branch, Marine Corps History Division, Quantico, VA.

${ }^{61}$ Harry Watkins, memo for Department Commander, Department of the North, 14 September 1927, "Voodoo and Witcheraft Cases," RG 127, A1, entry 21, NARA, hereafter Watkins memo.
} 
in 1927. When asked whether she "really caused the death" of her mother, St-Ilmar Jean confessed, "Yes, Judge. It is really I who had my mother killed." ${ }^{62}$ Because she believed her mother, Christine Crispin, had cursed her children and caused their deaths, St-Ilmar Jean decided to conspire with two relatives to kill her mother. St-Ilmar justified this action "the only way I could get rid of her. . . My mother really was a detestable 'loup-garou'." '63 St-Ilmar Jean's relatives subsequently killed her mother with machetes. Here again, Haitian peasants believed this gruesome violence was permissible because the daughter believed her mother to be a werewolf, and her own words revealed no remorse about her part in the murder conspiracy. The end of the report stated that St-Ilmar Jean's case went to a Haitian criminal court, but no verdict had been rendered even after several months. ${ }^{64}$ From the Marines' perspective, this could have been considered an easy conviction. However, as seen already, the Haitian judiciary could be moved by Voodooism to make acquittals.

In other murder cases, even when evidence pointed toward a guilty verdict, the Haitian courts could be swayed by Voodooism. Two examples represented what could best be termed justifiable homicide. An accused Haitian man testified that he killed a woman because she was a werewolf that had allegedly caused the death of his child. Another case included testimony by several Haitians that they killed a man "because he has been eating their children." Cannibalism of humans could not be considered to be the proper practice of Voodoo. The fact that both were examples of self-defense and thus permitted by Voodoo notions of morality contributed to the Haitian courts' decisions to acquit the defendants of murder charges. ${ }^{65}$ Latin American historian Alan McPherson offers useful interpretations of the courts' decisions. He argues that they represented one means to resist the Marine occupation in Haiti: "Resistance through courts con-

\footnotetext{
6. Watkins memo.

${ }^{63}$ Watkins memo.

64 Watkins memo.

${ }^{65}$ Gray memo; and Karen McCarthy Brown, "Afro-Caribbean Spirituality: A Haitian Case Study," in Michel and Bellegarde-Smith, Invisible Powers, 1-26.
}

sisted of efforts to side with non-insurrectionists and non-activists who simply engaged in cultural and economic activities that were banned by the occupation forces." The Haitian courts' goal in these acquittals, writes McPherson, "was not to harm the occupation but to continue living as in pre-occupation days." ${ }^{16}$

The acquittals in the Haitian court system frustrated the Marines as they attempted to impose order. In a letter written in 1927, a Marine major named John R. Henley complained "that our intelligence files for the last year contain several cases of crimes (murder) committed for purposes of eliminating 'loup garou' from the scene of action. You have copies of these reports sent to Hqers. [headquarters] in connection with this miscarriage of justice." ${ }^{167}$ These last wordsmiscarriage of justice-need to be highlighted because Henley believed that Voodoo could not be used as an excuse to undermine law and order.

More insightful analysis can be drawn from another part of Henley's letter. He possessed a sophisticated and nuanced view of Voodoo and its place in Haitian culture and life, when he conceded, "I have made very careful inquiries of all my officers and others and I can find no single case where the alleged vodoo [sic] dances have led to disorderliness etc or directly to other crimes." He observed substantive distinctions between uses of Voodoo, differentiating between the relatively benign practice of rituals and the practice to justify criminal behavior. Henley's comments should be contextualized as the commander of the Department of the North in Haiti. In this position, he received reports regarding the investigation of the death of Emmanuel Philinmon later in 1928. Henley's observation is as applicable (as is this entire article) to American occupations of culturally diverse

\footnotetext{
${ }^{66}$ McPherson, "The Irony of Legal Pluralism," 1159-6o.

${ }^{67}$ The subsequent document of 1 October 1927 does not give Henley's rant, but the rank of major is given in Navy Directory: Officers of the United States Navy and Marine Corps, October 1, 1928 (Washington, DC: Government Printing Office, 1928), 38. See also John R. Henley to [?] Bevau, 1 October 1927, "Voodoo and Witcheraft Cases," RG 127, A1, entry 21, NARA.
} 
nations in the twenty-first century as it was in $1927 .{ }^{68}$

In addition to Henley, other Marines maneuvered within Haitian social and religious contexts. Marine Sergeant Faustin E. Wirkus gained notoriety for his tolerance of Haitians and their religion while he served on the island of La Gonâve along the coast near Port-au-Prince. He tried to dispense justice in court cases quickly and fairly. The Haitians supposedly crowned Wirkus "king" of the island. ${ }^{69}$ Another Marine officer, Merwin Silverthorn, asserted that "out in the country voodooism was a form of entertainment." ${ }^{\circ}$ He thus shared a less negative attitude about the Haitians' religion.

\section{Epilogue and Conclusions: The Small Wars Manual and Beyond}

During the occupation from 1915 to 1934 , the U.S. Marines achieved some successes in Haiti including establishing and training the Gendarmerie d'Haiti and later the Garde d'Haiti. The Marines directed the construction of roads, hospitals, and other public buildings in hopes of modernizing Haiti's virtually nonexistent infrastructure. They tried to decrease, but never did eliminate, the rampant corruption in Haiti's political and judicial systems. All these activities laid a foundation for what they hoped would remain a democratic and free Haiti. These hopes came to nothing because of the occupation's wasted opportunities or short-term successes. The "Haitianization" of government, judicial, and military functions could not

\footnotetext{
${ }^{68}$ See Enclosure to the District Commander, Cerca La Source, memorandum for the Department Commander, Subject: Report on Death of Emmanuel Philinmon, 25 July 1928, Seldon Kennedy File 3248, Historical Reference Branch, Marine Corps History Division, Quantico, VA. ${ }^{69}$ Review of The White King of La Gonave, Marine Corps Gazette 15, no. 5 (May 1931): 15; and Francis J. Jancius, "The Sergeant Wore a Crown," Marian (October 1953): 5-6, in "Haiti" file, Historical Reference Branch, Marine Corps History Division, Quantico, VA. See also Faustin Wirkus and Taney Dudley, The White King of La Gonave (Garden City, NY: Doubleday, Doran, 1931). For another embellished work that helped to shape American consciousness of the Marines, Haiti, and Voodoo, see W. B. Seabrook, The Magic Island (New York: Harcourt Brace, 1929).

${ }^{70}$ Silverthorn, oral history interview transcript, 160 .
}

provide a viable foundation..$^{1}$ In terms of politics, the Marines had created a government structure in Haiti that remained dependent on their ongoing support, yet that same structure also aroused the ire of Haitians and thus could barely function even when propped up by the Marines. The combination of mutual conflict and mutual dependence created a catch-22 for the Marines in Haiti. Just as happened in other Latin American nations after American occupations ended in the early twentieth century, so too did the structures in Haiti collapse when the Marines departed. The nation plunged once again into alternating periods of dictatorship or anarchy in the subsequent decades. ${ }^{72}$

In addition to political and economic missteps, the Marine occupation in Haiti can be seen in some ways as a cautionary tale of cultural misunderstandings. Too few Marines appreciated the religious and cultural factors at play in Haiti, such as-most notably for purposes of this article-the practice of Voodoo. To read Brigadier General John H. Russell's evaluations during his tenure as high commissioner in the 1920s, Haiti went from a nation where "Vaudoism was rife and Human sacrifice was not uncommon" to a nation that benefited from "the introduction of the tenets of modern civilization" that "has done much to stamp out this Horrible Practice." 73 Reality proved to be different, however. The Marines failed to suppress Voodoo; instead, they alienated many otherwise dispassionate Haitians. The Marines rarely grasped how or why this religion was so central to Haitian life. Such confusions in turn restricted and ultimately negated

${ }^{71}$ The word Haitianization is used in proper historical context of the early 1930 , as seen in "Agreement between the United States and Haiti for Haitianization of the Treaty Services, Signed August 5, 1931," in Joseph V. Fuller, ed., Papers Relating to the Foreign Relations of the United States, 1931, vol. 2 (Washington, DC: Government Printing Office, 1946), 403-6, on Office of the Historian, Department of State (website), accessed 20 December 2019 .

${ }^{72}$ Pamphile, Contrary Destinies, 28-44. For overviews of the Marines' withdrawal, see Vandegrift, Once a Marine, 58; McCrocklin, Garde d'Haiti, 1, 186; Scheina, Latin America's Wars, 45-46; and Renda, Taking Haiti, 36 73 John H. Russell, "A Marine Looks Back on Haiti," [ca. 193os], Russell Papers, folder 6, box 3, Archives Branch, Marine Corps History Division, Quantico, VA, 35; and Russell, "Some Truths about Haiti," [ca. 1930s], Russell Papers, folder 2, box 3, Archives Branch, Marine Corps History Division, Quantico, VA. 
the occupation's effectiveness in achieving the mission of modernizing and democratizing the nation.

In analyzing the occupations of Haiti and other Latin American nations, historian Ellen Tillman asserts that "the exportation of the U.S. institutions through the use of the military" were "experiments."74 The term experiments is key to understanding the Marine occupations in the region. No doctrines existed for achieving grand political and economic objectives in Haiti. Moreover, no careful consideration went into understanding cultural features such as Voodooism. Instead, many Marines dismissed the religion as immoral and superstitious at best, or unlawful and dangerous at worst. In almost all cases, they tried to suppress Voodoo practices through civil and criminal legal channels. There is no denying that suppression failed due in part to the prejudices held by so many Marines and other Americans. Yet, on another level, Tillman's term experiment is critical to include in this discussion because it points to another institutional reason for failure, or perhaps more accurately, another reason success was impeded. Without the selfreflection ideally yielded by doctrines, the Marines had to make up the occupation process, including their attempt to stamp out Voodoo, as they went along.

With the occupations ending in the early 1930s, the Marines could step back and assess the successes and failures in Haiti and other nations in Latin America. This process took place at the Marine Corps Schools in Quantico, Virginia, in the 1934-35 academic year when Marine students and faculty captured lessons and codified doctrines in the Small Wars Manual of 1935, designated Navy and Marine Corps 2890 (NAVMC 2890), and subsequently in the revised edition of 1940. The term small wars differentiates military occupations such as the one in Haiti from those military operations in formally declared conflicts such as the First World War. The 1940 edition offers this clarification:

Small Wars vary in degrees from simple demonstrative operations to mili-

${ }^{74}$ Tillman, Dollar Diplomacy by Force, 81-82. tary intervention in the fullest sense, short of war. They are not limited in their size, in the extent of their theater of operations nor their cost in property, money, or lives. The essence of a small war is its purpose and the circumstances surrounding its inception and conduct, the character of either one or all of the opposing forces, and the nature of the operations themselves. $^{75}$

In twenty-first century parlance, the small wars concept equates to counterinsurgencies. As part of culling useful lessons from the occupation, the Marine Corps Schools sent surveys to officers who served in Latin America during the preceding decades. Those Marines spending time in Nicaragua, for example, received surveys with 40 questions dealing with tactical, operational, and logistical aspects. One asked, "What do you think of the suitability of the Browning Machine Gun, 30 calibre, for use on combat patrols? Of the 3 [inch] Trench Mortar? The Rifle Grenade? The Hand Grenade?" Another queried, "Do you think that a training center, and an Infantryweapons School should have been established in Managua?" And yet another asked, "Do you prefer horses or mules, and why?" The self-reflective, self-critical answers yielded ample evidence to fill the Small War Manual's 15 chapters covering logistics, combat operations, military governments, monitoring elections, and the arming and disarming of "native" groups, among other topics. ${ }^{7}$

In addition to these functional aspects, the manual also devotes space to less tangible cultural factors. The Marines did not use the word culture, but

\footnotetext{
75 Small Wars Manual, NAVMC 2890 (Washington, DC: Government Printing Office, 1940), 1.

${ }^{76}$ Vernon Megee, letter to E. B. Miller, 24 April 1933, box 1, Vernon Megee Papers, Dwight D. Eisenhower Library, Abilene, KS. See also David J. Ulbrich, "Revisiting Small Wars: A 1933 Questionnaire, Vernon E. Megee, and the Small Wars Manual," Marine Corps Gazette 9o, no. 11 (November 2006): 74-75.
} 
the terms they did employ fit under the concept of culture. ${ }^{77}$

Many decades later, the Corps' efforts in Haiti resemble the American counterinsurgency in Operations Iraqi Freedom and Enduring Freedom. Indeed, the similarities between American operations in Haiti and those in Iraq and Afghanistan are striking. The 1940 edition of the Small Wars Manual likewise served as a doctrinal foundation for Counterinsurgency, Field Manual 3-24/Marine Corps Warfighting Publication 3-33.5, completed by the U.S. Army and the Marine Corps in 2006..$^{8}$

$\cdot 1775^{\bullet}$
77 Again, the author is grateful to the anonymous peer reviewers for suggesting integrating Small Wars Manual into this article.
${ }^{8}$ Counterinsurgency, FM 3-24/MCWP 3-33.5 (Washington, DC: Headquarters, Department of the Army, 2006). 


\title{
The Birth and Early Years of Marine Corps Intelligence
}

by Michael H. Decker and William Mackenzie

\begin{abstract}
In an attempt to institutionalize the intelligence experiences gained by the American Expeditionary Forces in World War I, the U.S. Army published its first doctrinal publication on intelligence in 1920, Intelligence Regulations. On 18 August 1921, the Major General Commandant of the U.S. Marine Corps sent three copies of this classified Army publication to the commanding general at Marine Barracks, Quantico, Virginia. To understand what might cause this high-level transfer of an Army doctrinal publication, it is instructive to look at what was going on across the Marine Corps at this time-particularly in intelligence. Intelligence Marines often point to the 1939 reorganization of Headquarters Marine Corps and cite the creation that year of the staff M-2 as the birth of Marine Corps Intelligence, but many in the national intelligence community point to the creation of the Office of Strategic Services (1942-45) as the birth of the intelligence community; prior to that, there was no dedicated or formal U.S. intelligence service outside of the military. A look at how the intelligence lessons learned from World War I resulted in organizational changes in the interwar years reveals significant intelligence activity in the Marine Corps during that period and predates the 1939 reorganization of Headquarters Marine Corps. Keywords: intelligence community, Marine Corps Intelligence, Headquarters Marine Corps reorganization, World War I intelligence, intelligence service, Division of Operations and Training, Military Intelligence Section, Division of Plans and Policies, staff M-2, Office of Strategic Services, Office of Naval Intelligence, American Legation U.S. naval attaché, A/ALUSNA, U.S. Army intelligence doctrine, Intelligence Regulations, On-the-Roof Gang, Communications Security Section
\end{abstract}

I $\mathrm{n}$ an attempt to institutionalize the intelligence experiences gained by the American Expeditionary Forces (AEF) in World War I, the U.S. Army published its first doctrinal publication on intelli-

Michael Decker served as a Marine infantry officer with the ad Battalion, 6th Marines, in Beirut, Lebanon, as part of the Multinational Peacekeeping Force and as a Marine intelligence officer with I Marine Expeditionary Force G-2 during Operation Desert Storm. He served as director of intelligence, U.S. Marine Corps, from January 2004 to June 2005. William Mackenzie served with the $2 \mathrm{~d}$ Battalion, 6th Marines, as a squad leader on deployments to the Middle East and Afghanistan, including 2010 in Marjah. He has a bachelor of arts in international relations from American University and is currently pursuing a master of arts in security policy analysis from George Washington University.

https://doi.org/10.35318/mch.2019050203 gence in 1920, Intelligence Regulations. On 18 August 1921, the Major General Commandant of the U.S. Marine Corps sent three copies of this classified Army publication to the commanding general at Marine Barracks, Quantico, Virginia. The letter was signed by Brigadier General Logan Feland "by direction" and the receipt was returned signed by a future Commandant, Lieutenant Colonel Thomas Holcomb, then chief of staff to Brigadier General Smedley D. Butler. ${ }^{1}$

\footnotetext{
${ }^{1}$ MajGen Cmdt letter to CG Quantico, U.S. Marine Corps, 1975-35-AO47-cel.-56, Subj. Intelligence Regulations, 18 August 1921, box 5, Division of Operations and Training, Intelligence Section, General Correspondence, 1919-1939, Record Group (RG) 127, National Archives and Records Administration (NARA).
} 
To understand what might cause this high-level transfer of an Army doctrinal publication, it is instructive to look at what was going on across the Marine Corps at this time. In the early years after World War I, veterans of the AEF worked to apply lessons learned on staff and unit organization, combined arms, and other tactics, techniques, and procedures to the organization of the Marine Corps for warfighting and at Headquarters Marine Corps. This was especially true of intelligence.

Intelligence Marines often point to the 1939 reorganization of Headquarters Marine Corps and cite the creation that year of the staff M-2 as the birth of Marine Corps Intelligence. Marines are not alone in the view that World War II or the run-up to it began the formal approach to the craft of intelligence. Many in the national intelligence community point to the creation of the Office of Strategic Services as the birth of the intelligence community; prior to that, there was no dedicated or formal U.S. intelligence service outside of the military. As former intelligence officer Dr. Mark Stout asserts, "Historians and practitioners generally date the origins of modern American intelligence to the Office of Strategic Services (1942-1945) and the National Security Act of 1947 which created the CIA and the U.S. Intelligence Community."'However, an analysis of how the intelligence lessons learned from World War I resulted in organizational changes in the interwar years reveals significant intelligence activity in the Marine Corps during that period and predates the 1939 reorganization of Headquarters Marine Corps.

\section{Post-World War I Reorganization of the Marine Corps}

Until a few years before World War I, the Marine Corps had essentially no Headquarters Staff as we think of it today. The Major General Commandant oversaw the Marine Corps through a small personal staff and three staff departments: Adjutant and Inspector, Quartermaster, and Paymaster. It was not

\footnotetext{
${ }^{2}$ Mark Stout, "World War I and the Birth of American Intelligence Culture," Intelligence and National Security 32, no. 3 (2017): 378, https://doi .org/10.1080/02684527.2016.1270997.
}

until April 1911 that the Office of Assistant to the Commandant was created, headed by Colonel Eli K. Cole, who served as what today would be called a chief of staff. 3 Colonel Cole was replaced in January 1915 by Colonel John A. Lejeune.

Since World War I began in August 1914, the Major General Commandant, as well as the secretary of the Navy and the chief of naval operations, had pushed for increases of manpower and materiel, to include larger staffs. This led to the Naval Act of 1916, which increased the Corps' size by about 50 percent, from 344 officers and 9,921 enlisted to 597 officers and 14,981 enlisted. ${ }^{4}$ It also authorized emergency increases up to 693 officers and 17,400 enlisted, which occurred on 26 March 1917.5 The act allowed for 8 percent of the officers, or 55 of the 693 , to serve in the staff departments.

By fall 1918-after Marines had fought in Belleau Wood, Soissons-Château-Thierry, and SaintMihiel-the 12th Major General Commandant, George C. Barnett, decided to create a planning section. On 19 December 1918, the Headquarters Planning Section was established and charged with "all matters pertaining to plans for operations and training, intelligence, ordnance, ordnance supplies and equipment." At first, the Planning Section, under direct supervision of the Office of the Assistant to the Commandant, only had three officers. ${ }^{6}$

World War I was a driving factor in the decision to create a Planning Section, with intelligence as one of many functions identified for improvement based on shortcomings experienced during the war. During World War I, Marine officers interacted with and learned from other branches of the AEF and other armies, such as the French. The Army's Military Intelligence Division (MID) and the U.S. Office of Naval Intelligence $(\mathrm{ONI})$ were larger and more sophisticated

${ }^{3}$ Kenneth W. Condit, Maj John H. Johnstone, and Ella W. Nargele, A Brief History of Headquarters Marine Corps Staff Organization (Washington, DC: Historical Division, Headquarters Marine Corps, 1971), 8.

${ }^{4}$ Naval Appropriations Act of 1916, Pub. L. No. 64-241 (1916).

${ }^{5}$ Maj Edwin N. McClellan, The United States Marine Corps in the World War (Washington, DC: Historical Branch, G-3 Division, Headquarters Marine Corps, 1920).

${ }^{6}$ Condit, Johnstone, and Nargele, A Brief History of Headquarters Marine Corps Staff Organization, 11. 


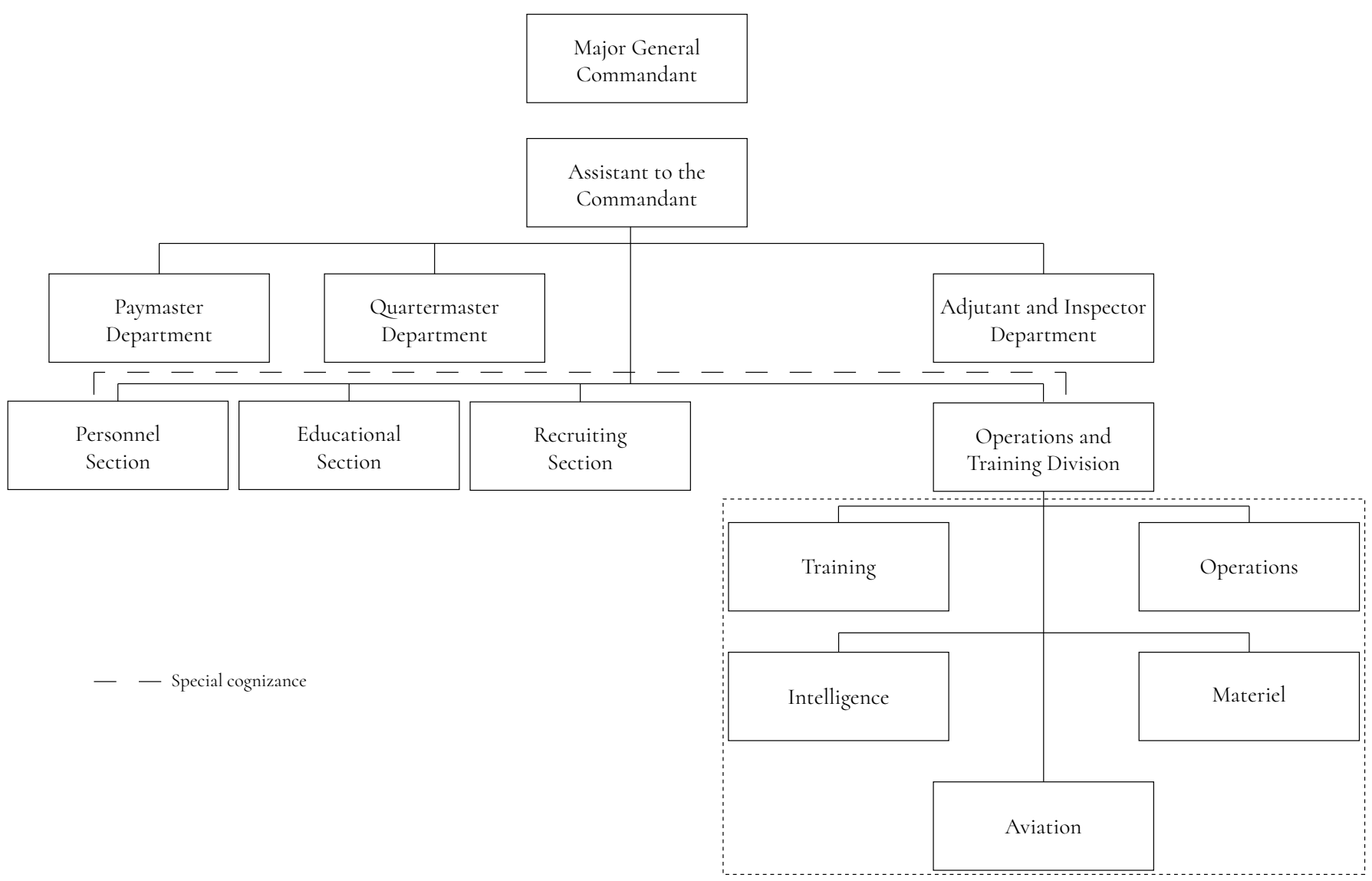

A Brief History of Headquarters Marine Corps Staff Organization, adapted by MCU Press Table of organization, Headquarters Marine Corps, 1 December 1920.

than the Marine Corps' intelligence efforts and staff organization. It is likely that the Marine Corps staff developed its own small intelligence section after World War I based on experience with the larger ONI and MID organizations.

Major General Lejeune became the Major General Commandant on 1 July 1920 and brought his experience of commanding the ad Division in the AEF and extensive use of a European staff system in those organizations to Headquarters. On 1 December 1920, Lejeune reorganized Headquarters and created the Division of Operations and Training, with Brigadier General Logan Feland as its first director. The Division of Operations and Training included Operations, Training, Materiel, Aviation, and Military Intelligence sections. ${ }^{7}$ Creation of the Military Intelligence

${ }^{7}$ Condit, Johnstone, and Nargele, A Brief History of Headquarters Marine Corps Staff Organization, 12.
Section represents the first permanent Marine Corps intelligence organization. Brigadier General Feland assigned Lieutenant Colonel Earl H. Ellis, who had been his brigade intelligence officer in the Dominican Republic, as the first head of the Military Intelligence Section. ${ }^{8}$

\section{Military Intelligence Section Activities}

In 1922, Brigadier General Feland wrote in the Marine Corps Gazette that he saw the Division of Operations and Training as essential for the Marine Corps to mitigate future losses in combat and increase organizational readiness. He stated that the Military Intelligence Section's principal function was the "collection and compilation of intelligence useful to the Marine

${ }^{8}$ David J. Bettez, "Quiet Hero: MajGen Logan Feland," Marine Corps Gazette 92, no. 11 (November 2008): 61. 
Corps, in carrying out its mission." 9

There is ample evidence of the Military Intelligence Section collecting and compiling information. Many Marines are familiar with the legend of Lieutenant Colonel Ellis writing Advanced Base Operations in Micronesia in 1921 and then being found dead in Palau in 1923 while on an intelligence or reconnaissance mission. ${ }^{10}$ What few Marines may know is that with no professional or career intelligence officers, all officers in the Division of Operations and Training could move between sections and perform a variety of duties as needed. Ellis, for example, simultaneously headed the Military Intelligence Section and wrote those advanced basing plans that guided Marine Corps war planning for the subsequent 25 years.

As evidenced by the Headquarters letter forwarding the 1920 Army doctrinal publication Intelligence Regulations, the Military Intelligence Section also took part in the Division of Operations and Training's other efforts, such as "organization of units, matters of training, choice of most suitable arms and equipment, military schooling, etc." ${ }^{11}$

On 10 January 1921, a month after the Military Intelligence Section was formed, it promulgated a "List of Intelligence Regulations, etc. Transmitted to Certain Marine Corps Units. ${ }^{{ }^{12}}$ The list included items such as the aforementioned Intelligence Regulations, along with various other military orders, articles, and reports. A few excerpts from items on the list highlight the type of things this 40-day-old Headquarters office determined would be of use to Marine Corps Schools and "certain" field units.

"Front Line Intelligence, extract from an article in the Marine Corps Gazette, December 1920, by Major Ralph Sto-

\footnotetext{
9 BGen Logan Feland, "The Division of Operations and Training Headquarters U.S. Marine Corps," Marine Corps Gazette 7, no. 1 (March 1922): 42.

${ }^{10}$ Earl H. Ellis, Advanced Base Operations in Micronesia, Fleet Marine Force Reference Publication 12-46 (Washington, DC: Headquarters Marine Corps, 1992).

${ }^{11}$ Feland, "The Division of Operations and Training Headquarters U.S. Marine Corps," 41.

12. "Instructions on Marine Corps Intelligence," letter CF-152-AO-15, 10 January 1921, box 5, Division of Operations and Training, Intelligence Section, General Correspondence, 1919-1939, RG 127, NARA.
}

ver Keyser."13 Major Keyser had served as commanding officer of $2 \mathrm{~d}$ Battalion, 5th Marines, June-July 1918 during battles in the Château-Thierry sector and the Aisne-Marne offensive; then, August 1918-August 1919, he served as Major General Lejeune's assistant chief of staff, G-2 (Intelligence Department), in the $2 \mathrm{~d}$ Division, AEF. The article was a tour-de-force of tactical intelligence support on intelligence functions at the division, regiment, and battalion level. Major Keyser noted, "Military intelligence is more than reliable information, it is reliable information furnished in time to permit appropriate action." ${ }^{14}$

"Intelligence Service in the Bush Brigades and Baby Nations, Extracts from a 1920 report by Major Earl Ellis." Ellis noted, "In executing the intelligence functions stated the most difficult problem of all is to force the personnel to realize that their mission is not to gather information of any kind and place it on file, as is generally the custom, but to gather pertinent information, put it in proper form for use and then place it in the hands of the person who can use it to best advantage-and this as quickly as possible. ${ }^{\prime \prime 6}$

"Functions of Intelligence Officers in War Plans, Extract from U.S. Army Instructions to Intelligence Officers by Military Intelligence De-

\footnotetext{
13 "Instructions on Marine Corps Intelligence," original emphasis removed.

${ }^{14}$ Maj Ralph S. Keyser, "Military Intelligence," Marine Corps Gazette 5, no. 4 (December 1920): 321.

15 "Instructions on Marine Corps Intelligence," original emphasis removed.

${ }^{16}$ Maj Earl Ellis, Intelligence Service in the Bush Brigades and Baby Nations (Washington, DC: Headquarters Marine Corps, 1920), enclosure to "Instructions on Marine Corps Intelligence," original emphasis removed.
} 
partment, 1921." ${ }^{17}$ This Army doctrine stated, "As the plan is built up, every portion should be submitted to you for attack as the enemy's representative-this for the purpose of providing the means of disinterested construction $[$ sic] criticism. Your mental attitude in doing this work should be that of the enemy's Chief of Staff, who, supposedly having captured the plan, strives to make arrangements to circumvent it." ${ }^{\prime 8}$

These examples show how the combined lessons of small wars and the AEF in World War I instructed these officers that newly formed Marine Corps intelligence staffs should focus on tactical and operational intelligence support that was very practical and directly tied to current operational planning and decision making. However, the Military Intelligence Section was dividing its time between this type of "force development" activity (as it might be called today) and the need to do other longer-range planning and interagency coordination.

Brigadier General Feland noted that the Division of Operations and Training "has been charged with certain responsibility in regard to the policy to be followed in selecting the personnel for assignment to certain duties. ${ }^{19}$ Examples of this would include detailing of Marines to the ONI, naval attaché duty, special training in areas such as communications intelligence, and special reconnaissance missions.

\section{Service in ONI}

The ONI was established in the Bureau of Navigation in March 1882 by Navy Department General Order No. 292, nearly 40 years before the fledgling Headquarters

\footnotetext{
${ }_{17}$ "Instructions on Marine Corps Intelligence," original emphasis removed.

${ }^{18}$ U.S. Army Instructions to Intelligence Officers, 1921, enclosure to "Instructions on Marine Corps Intelligence."

${ }^{19}$ Feland, "The Division of Operations and Training Headquarters U.S. Marine Corps," 42.
}

Military Intelligence Section. ${ }^{20}$ Marines served at ONI prior to the creation of the Corps' Military Intelligence Section, with the first Marine, First Lieutenant Lincoln Karmany, being assigned to ONI in January $1893 .{ }^{21}$ Captain (later Major) William L. Reddles served as assistant naval attaché in Tokyo, Japan, from 1915 to 1918 and then served as a lieutenant colonel in ONI from 1920 to 1921 . In the 1930 , there were often three to five Marine officers at ONI, most often serving in or leading the Far East and Latin American sections. ${ }^{22}$ For example, Captain Ronald Aubry Boone, who served as S-2, 4th Marine Regiment, in Shanghai at the start of the Sino-Japanese War in 1937, was promoted to major and assigned to ONI in 1939 as assistant head of the Far East Section.

While we do not have evidence that duty at ONI was viewed as career enhancing by Marines of that era, we do know that many Marines who served at ONI were later promoted to colonel and general officer ranks. A future Commandant (1934-37), Major John H. Russell Jr., came to ONI in 1913 after serving as commander of the Marine Detachment, American Legation, Peking (Beijing), China. In 1916, Major Russell worked with Navy Commander Dudley W. Knox on a reorganization plan for ONI that was approved by Secretary of the Navy Josephus Daniels on 1 October 1916. In early 1917, Major Russell took charge of Section A, Organization and Control of Agencies for the Collecting of Information, which included debriefing of commercial travelers as well as control of hired agents and informants. ${ }^{23}$ Lieutenant Colonel John C. Beaumont served in ONI in 1920, was promoted to colonel in 1926, commanded 4th Marines in 1933, and was promoted to brigadier general in $1935 .{ }^{24}$

Brigadier General Dion Williams is considered the father of amphibious reconnaissance based on his

\footnotetext{
${ }^{20}$ Capt Wyman H. Packard (USN), A Century of U.S. Naval Intelligence (Washington, DC: Office of Naval Intelligence and the Naval Historical Center, 1996), 2.

${ }^{21}$ W. H. Russell, "The Genesis of FMF Doctrine: $1879-1899$," Marine Corps Gazette 35, no. 4 (April 1951): 57; and Packard, A Century of U.S. Naval Intelligence, 7 .

${ }^{22}$ Packard, A Century of U.S. Naval Intelligence, 344-53.

${ }^{23}$ Packard, A Century of U.S. Naval Intelligence, 41, 331.

${ }^{24}$ BGen John C. Beaumont biographical file, "Military History of BGen John C. Beaumont," Historical Reference Branch, Quantico, VA.
} 
book Naval Reconnaissance, which he wrote in 1905-6 while a major on the instructor staff at the Naval War College. ${ }^{25}$ He served as a staff intelligence officer in ONI and on intelligence duty abroad from November 1909 to March 1913. From 1924 to 1925, as a brigadier general, he was director of operations and training at Headquarters and supervised the Military Intelligence Section. ${ }^{26}$

\section{U.S. Naval Attachés Abroad}

In 1910, the first of many Marines was sent to Tokyo to serve as assistant American Legation U.S. naval attaché in Tokyo for language training. Most notably, Captain Ralph Stover Keyser, who later served as Major General Lejeune's G-2 in France, served as assistant naval attaché at the American embassy in Tokyo from January 1912 to February 1915. Marine officers served in Tokyo, gaining Japanese language capability, through summer 1941, when the decision was made to withdraw the naval attaché office from Japan. The two Marines evacuated in 1941 were Captain Bankson T. Holcomb Jr. and First Lieutenant Ferdinand W. Bishop. ${ }^{27}$ Holcomb would go on to serve as director of intelligence at Headquarters in 1957.

Marines were normally assigned as assistant naval attachés. Lieutenant Colonel James C. Breckinridge was the first Marine to serve as the naval attaché, being assigned to Christiania (now Oslo), Norway, in 1917 with the added duty of covering Denmark and Sweden. In the interwar years, more Marines served in unique or first-time attaché roles. Captain David R. Nimmer was sent to Moscow in March 1934 as the assistant naval attaché, but ended up as the second Marine naval attaché because the Navy officer assigned as naval attaché to Moscow turned down his orders. ${ }^{28}$ Perhaps the most famous Marine of this period to serve as an assistant naval attaché was Colonel Pedro

\footnotetext{
${ }^{25}$ Maj Dion Williams, Naval Reconnaissance: Instructions for the Reconnaissance of Bays, Harbors, and Adjacent Country (Washington, DC: Government Printing Office, 1906).

${ }^{26}$ BGen Dion Williams biographical file, "Military History of BGen Dion Williams," 30 September 1925, Historical Reference Branch, Quantico, VA, hereafter "Military History of BGen Dion Williams."

${ }^{27}$ Packard, A Century of U.S. Naval Intelligence, 367.

${ }^{28}$ Packard, A Century of U.S. Naval Intelligence, 69.
}

A. del Valle, who later commanded the 11th Marine Regiment (Artillery) at Guadalcanal and the 1st Marine Division at Okinawa and would retire as a lieutenant general. Colonel del Valle served as assistant naval attaché in Rome, Italy, from 1935 to 1936 and was a military observer with the Italian Army during its campaigns in Ethiopia. ${ }^{29}$

\section{Communications Intelligence}

Department of the Navy communications intelligence began in the fashion of one-at-a-time, on-the-job training for experienced communications and linguist personnel. This activity was controlled by the director of naval communications within the Communications Security Section, which was formed in 1922. By 1926, the Communications Security Section began to conduct small training classes for officers, and the first class included Captain Leo F. S. Horan. By 1928, Communications Security Section began classes for enlisted intercept operators in a classroom that was constructed on the roof of the main Navy building in Washington, DC, earning intercept operators who graduated the course the nickname "On-the-Roof Gang" or OTRG. Two of the classes were entirely comprised of Marines..$^{30}$

Some of the Marines detailed to Japan for foreign language training did follow-on tours of duty at radio intercept stations. First Lieutenant Alva B. Lasswell was sent to Tokyo for Japanese language training from 1935 to 1938 , to the 16 th Naval District's C Station radio intercept station (Corregidor) in 1938-39, and Shanghai in $1939 .{ }^{31}$ Lasswell's tour at C Station exposed him to the technical aspects of communications intelligence: cryptanalysis, traffic analysis, and translation, since all were performed at Corregidor in

29 LtGen Pedro A. del Valle biographical file, "Biography, Lieutenant General Pedro A. del Valle, USMC (Ret),” AH-1265-HPH, 3 January 1951, Historical Reference Branch, Quantico, VA.

${ }^{\circ}$ Frederick D. Parker, Pearl Harbor Revisited: U.S. Navy Communications Intelligence, 1924-1941, series 4: World War II, vol. 6, 3d ed. (Fort George C. Meade, MD: National Security Agency, Center for Cryptologic History, 2013), 10-11. OTRG was often applied to all radio intercept operators regardless of whether they had graduated from the OTRG school.

${ }^{31}$ Packard, A Century of U.S. Naval Intelligence, 370. C Station was also referred to as CAST. 
support of both the Asiatic Fleet and Army General Douglas MacArthur. ${ }^{22}$

Although not an activity of the interwar years, it is worth noting that experience gained by this small group of linguists and cryptologists in Japan and China directly contributed to the success of the U.S. Pacific Fleet in World War II (WWII). Alva Lasswell was the linguist and cryptologist who later decrypted and translated the message traffic in 1942 that led to the Battle of Midway and the 1943 traffic that led to the downing of Admiral Isoroku Yamamoto's plane. ${ }^{33}$ It is also interesting to note that Marines were assigned to Fleet Radio Unit Pacific performing communications intelligence as WWII began, with Marines such as Bankson Holcomb taking a "direct support" radio intercept unit aboard USS Enterprise (CV 6) for the February 1942 Marshalls-Gilberts raids.

\section{Special Reconnaissance}

Special duty assignments-in this case of intelligence, reconnaissance, and related missions-were accounted for in the U.S. Navy regulations of 1920, which stated in article 127 , section 2, of its chapter on general instructions to officers that "no officer of the Navy or of the Marine Corps shall proceed to a foreign country on special duty connected with the service except under orders prepared by the Bureau of Navigation or by the Major General Commandant as the case may be, and signed by the Secretary of the Navy."34 While records do not note how many Marines were detailed to special duty assignments in the interwar years, the provision of Navy regulations citing the Major General Commandant's authority to prepare such orders indicates anticipation that Marines would be used in this manner. Perhaps the most famous special duty assignment of a Marine during this period is the mission of Lieutenant Colonel Ellis to survey islands in East

\footnotetext{
${ }^{32}$ Robert Louis Benson, A History of U.S. Communications Intelligence during World War II: Policy and Administration, series 4: World War II, vol. 6 (Fort George C. Meade, MD: National Security Agency, Center for Cryptologic History, 1997).

33 Dick Camp Jr., "Listening to the Enemy: Radio Security Stations, China-'Get Yamamoto'," Leatherneck 87, no. 1, January 2004, 40-43.

34 United States Navy Regulations, 1920 (Washington, DC: Government Printing Office, 1920), 40 .
}

Asia. Ellis's special duty was approved by the Major General Commandant and the secretary of the Navy. Unfortunately, the mission ended with Ellis's death in Palau in $1923 .{ }^{35}$

Another example of a special duty reconnaissance mission is the work of then-major William Arthur Worton in China from 1935 to $1936 .{ }^{36}$ Major Worton, who as a platoon commander during World War I had been badly wounded in a gas attack in Belleau Wood, was assigned to ONI's Far East Section after several tours of duty in China, including completion of the State Department's Chinese language course in Beijing and a tour as an intelligence officer in 3d Brigade under Major General Smedley Butler. While serving at ONI, Worton proposed the fleet intelligence officer of the Asiatic Fleet be assigned an assistant who would be based in Hong Kong or Shanghai to recruit and deploy foreign agents to Japanese ports to observe and report on the Japanese Navy. Worton was sent to Shanghai to execute his plan, which he did undercover as a businessman. Worton was able to set up an agent network, but he recommended successive Marines assigned to this duty be designated assistant naval attachés because the proximity of Shanghai's international settlement to the 4 th Marines often meant running into fellow Marine officers who did not always believe he was there to start a business.

\section{Organization and Manning}

As noted earlier, the Division of Operations and Training also had the lead for "organization of units, matters of training, choice of most suitable arms and equipment, military schooling, etc." ${ }^{37}$ Today, this would be called force development or even an occupational field sponsor role, although we note intelligence was not yet a Marine Corps military occupational specialty at this time. The Military Intelligence Section likely assisted the Division of Operations and Train-

\footnotetext{
${ }^{35}$ LtCol P. N. Pierce, "The Unsolved Mystery of Pete Ellis," Marine Corps Gazette 46, no. 2 (February 1962): 34-40.

${ }^{36}$ Dennis L. Noble, "A US Naval Intelligence Mission to China in the 1930s," Studies in Intelligence 50, no. 2 (2006).

${ }^{37}$ Feland, "The Division of Operations and Training Headquarters U.S. Marine Corps," 41.
} 
Table 1. Authorized intelligence staff per unit.

\begin{tabular}{lcc}
\hline & Officers & Enlisted \\
\hline For each independent brigade headquarters & 1 & 10 \\
For each brigade forming part of a division & 1 & 2 \\
For each regimental headquarters & 1 & 1 \\
For each battalion of infantry & 1 & 13 \\
For each battalion of artillery & 1 & 1 \\
Air Service, per wing & 1 & 1 \\
\hline
\end{tabular}

MajGen Cmdt letter to Brigade Cmdr, First Provisional Brigade, U.S. Marine Corps, Port-au-Prince, Republic of Haiti, 1975-35-AO-15-rac, Subj. Combat Intelligence, 17 June 1921, box 5, Records of the U.S. Marine Corps, Division of Operations and Training, Intelligence Section, General Correspondence, 1919-1939, RG 127, NARA

ing in developing tables of organization and equipment for intelligence sections and units.

In 1921, the Major General Commandant authorized creation of combat intelligence personnel billets in deployed Marine Corps units. ${ }^{38}$ In the following year, the Marine Corps assigned a new four-section executive staff-including personnel, intelligence, operations and training, and supply-to brigades and infantry regiments. These staff sections did not use the conventional G-2 if the unit was commanded by a general and S-2 if the unit had a more junior commander. Rather, the convention was B-2 for brigade intelligence officers and R-2 for regiments. Finally, in 1925 , planning tables of organization under consideration should the Marine Corps need to field divisions also showed the four-section executive staff. 39 An example of the envisioned size of intelligence staffs and units at various echelons is shown above (table 1)..$^{\circ}$

The Military Intelligence Section also served as a conduit to the brigades for Army doctrinal publications. In addition to the aforementioned classified

\footnotetext{
${ }^{38}$ MajGen Cmdt letter to Brigade Cmdr, First Provisional Brigade, U.S. Marine Corps, Port au Prince, Republic of Haiti, 1975-35-AO-15-rac, Subj. Combat Intelligence, 17 June 1921, box 5, Division of Operations and Training, Intelligence Section, General Correspondence, 1919-1939, RG 127, NARA, hereafter MajGen Cmdt letter to brigade cmdr.

39 Condit, Johnstone, and Nargele, A Brief History of Marine Corps Staff Organization, 15 .

$4^{\circ}$ MajGen Cmdt letter to brigade cmdr.
}

Intelligence Regulations, operational- and tactical-level Army publications, such as the Army's Provisional Combat Intelligence Manual, were mailed directly to deployed brigades. ${ }^{41}$

Typically, officers were assigned as brigade/ regimental intelligence officers, while enlisted Marines served as scouts/observers, messengers, or topographical draftsmen. ${ }^{42}$ Since there was no intelligence military occupational specialty, recommendations were sent to the brigades to assist in screening Marines for duty in intelligence staffs and units. The screening criteria were:

1. Especially smart, active, intelligent, and trustworthy.

2. Sober and temperate habits.

3. Physically fit for great strain and hardship.

4. Keen observer; excellent eyesight and hearing.

5. Accurate shot; deliberate and yet quick.

6. Good judge of distance.

7. Strong will power and determination.

8. Courage, combined with coolness and self-reliance.

\footnotetext{
${ }^{41}$ Provisional Combat Intelligence Manual, Document 1041 (Washington, DC: War Department, 1920).

$4^{2}$ MajGen Cmdt letter to brigade cmdr.
} 
9. Capable, adaptable, original and resourceful.

10. Able to swim and ride a horse. ${ }^{43}$

\section{Evolution of Brigade Intelligence}

During the interwar period, Marine Corps intelligence evolved at the tactical levels of the independent Marine brigade and its subordinate units; its initial B-2 and S-2 organizations were derived from the World War I experience. General John J. Pershing arrived in Europe in June 1917 with the first division of the AEF and decided to adopt the French staff system throughout the AEF. Intelligence became the second section, or G-2, of the AEF headquarters staff, and this convention was adopted in various forms at each echelon as more divisions, brigades, regiments, and battalions joined the AEF and personnel were sent to Allied intelligence training. Personnel designated to serve as intelligence officers were initially trained on document exploitation and prisoner-of-war interrogation at the British intelligence school at Harrow, but in August 1918, the AEF opened an intelligence training center at Langres, France. Intelligence students at Langres were trained to perform interrogations using actual captured German prisoners. ${ }^{44}$

The 5th Marine Regiment arrived in June 1917 with the first element of the AEF, and Marine units followed the AEF in creating intelligence staffs by taking personnel from line units, also taking advantage of the intelligence training schools set up in the field by the French, the British, and the AEF itself. By February 1918, the 6th Marine Regiment arrived and the 4 th Brigade was at strength. The 1st Battalion, 6th Marines, is a good example of a Marine unit adjusting to the AEF staff system. The battalion was commanded by Medal of Honor Recipient Major John Arthur Hughes. As the battalion went through what today would be called reception, staging, onward movement, and integration, Major Hughes reached into his 75th Company and pulled Second Lieutenant Carlton Burr to be the battalion intelligence officer, or S-2.

\footnotetext{
${ }^{43}$ Provisional Combat Intelligence Manual.

${ }^{44}$ John Patrick Finnegan and Romana Danysh, Military Intelligence, Army Lineage Series (Washington, DC: Department of the Army, 1998), 33.
}

Burr in turn asked $75^{\text {th }}$ Company for Sergeant Gerald C. Thomas, a future Assistant Commandant, to be the battalion intelligence chief. 45

Following the AEF model of battalion S-2s having a reconnaissance element of about 28 scouts, observers, and snipers, Major Hughes allowed Second Lieutenant Burr and Sergeant Thomas to form a 25man platoon of scout/observers who were also trained to sketch maps and troop positions, but over time Hughes acceded to demands from the line companies for the return of this manpower. ${ }^{46}$ Sergeant Thomas was only called back up to 1st Battalion, 6th Marines, headquarters to serve as acting $\mathrm{S}-2$ when Burr was medically evacuated the day before the Battle of Belleau Wood. Major Hughes's first order to Thomas was for a detailed map of the battalion's position. It was common for S-2s of that period to spend as much effort plotting friendly positions as enemy positions.

Until 1917, brigade and independent battalion staffs were organized similarly to Headquarters, with three staff officers: adjutant, quartermaster, and paymaster. In the 1920s, veterans of World War I, whether recipients of intelligence support or actual veterans of these ad hoc intelligence staffs and units, were reassigned to deployed Marine brigades, where the lessons learned were put into practice. Even before the new brigade and regimental tables of organization were issued in 1922 and 1925, respectively, brigade and regimental commanders were often using their own resources to arrange four-section staffs.

During most of the interwar period, the Marine Corps had three brigades deployed. The 1st Marine Brigade was located in Haiti/Dominican Republic before moving its flag to Quantico in 1933 . The 2d Marine Brigade was located in Nicaragua, and the $3 d$ Marine Brigade was stationed in China. The first-hand experiences of Marines on the ground in these areas led to the earlier-mentioned practice of Marines serving as heads of the Far East and Latin American Sections of ONI. As Navy intelligence historian Captain Wyman H. Packard noted, "In the

\footnotetext{
${ }^{45}$ Allan R. Millett, In Many a Strife: General Gerald C. Thomas and the U.S. Marine Corps, 1917-1956 (Annapolis, MD: Naval Institute Press, 1993), 26. ${ }^{46}$ Finnegan and Danysh, Military Intelligence, 35.
} 
mid-1930s, some of the principal sources for ONI's Far East [Section] (OP-16-B-11) were reports from Marine Corps intelligence officers stationed in China. Pertinent reports on Japanese-controlled islands in the Pacific were also submitted by overseas units of the Marine Corps." ${ }^{47}$

In 1927, the 4th Marine Regiment was sent to Shanghai, China, to protect key international zones and buildings during the Chinese civil war. The waror, as some called it, the Communist insurgency-was between the Nationalist Party of China and the Communist Party of China, but Japan took advantage of the 10 years of conflict to make gains on the periphery of China. Japan invaded Manchuria in 1931. Marines in Shanghai and with the Marine Detachment, American Legation Guard, Peking (Beijing), were referred to as the China Marines and came to know the country well, but perhaps more importantly, they were able to learn much about their future enemy, the Japanese military, during this period.

The Marine Corps placed the $3 \mathrm{~d}$ Brigade in Tientsin to take command of all Marines in China. The first commanding general was Brigadier General Smedley D. Butler, a veteran of the Marine expedition to China in 1900 to relieve the Legation Quarter and put down the Boxer Rebellion..$^{4}$ Major Earl C. Long served as the 3d Brigade B-2 and Captain Evans Fordyce Carlson served as the operations and training officer, $3 \mathrm{~d}$ Marine Brigade in Tientsin, and then as intelligence officer for $4^{\text {th }}$ Marines in Shanghai. ${ }^{49}$ Carlson would return to China in 1937 in various positions, including as an observer with Chinese 8th Route Army, where he was able to study Japanese Army capabilities firsthand. ${ }^{\circ}$

\footnotetext{
${ }^{47}$ Packard, A Century of U.S. Naval Intelligence, 43.

${ }^{48}$ Trevor K. Plante, "U.S. Marines in the Boxer Rebellion," Prologue 31, no. 4 (Winter 1999). Marine Corps officers were not eligible for the Medal of Honor until 1913, but given the slow pace of promotions, being advanced in numbers was a high reward. Then-1stLt Butler was advanced two ranks and brevetted a captain for bravery in action during the July 1900 battle for Tientsin.

49 BGen Evans F. Carlson biographical file, "Brigadier General Evans F. Carlson," AHC-1265-hph, 5 March 1951, Historical Reference Branch, Marine Corps History Division, Quantico, VA, hereafter Carlson biographical file.

$5^{\circ}$ Carlson biographical file.
}

The 3d Brigade was planning for the possibility that the Marine Detachment, American Legation, Peking (Beijing), would need to be relieved in similar fashion to the relief column that fought its way from Tientsin to Beijing during the Boxer Rebellion. In March 1928, Major Long completed a roster listing the forward echelon of a B-2, which he planned would consist of 2 officers and 10 enlisted Marines..$^{1}$ Ten enlisted Marines was what Headquarters had published in 1921 as the table of organization for a B-2 section in a deployed independent brigade. The composition of the B-2's 10 enlisted Marines was listed as follows in Major Long's plan:

$\begin{array}{ll}\text { Sergeant } & \text { In charge of field party } \\ \text { PFC } & \text { Field party and blueprint man } \\ 2 \times \text { PFCs } & \text { Draftsmen } \\ \text { PFC } & \text { Clerk } \\ \text { PFC } & \text { Motorcycle orderly } \\ \text { 2 x Private } & \text { Field party } \\ \text { Private } & \text { Moving picture operator } \\ \text { Private } & \text { Chauffer }^{2}\end{array}$

In Shanghai and Beijing, members of the OTRG, consisting of Navy staff and a detachment of Marines, targeted Japanese diplomatic communications, but also intercepted and relayed information regarding Japanese tactics, orders of battle, and objectives to Washington, DC, during the Japanese invasion of Manchuria and later attacks on Shanghai.53 The Navy established radio security stations in Shanghai during 1924 near the Asiatic Fleet headquarters and in Beijing, with the Marine detachment, during 1927. The Radio Security Station, Shanghai, or the Fleet Communication Intelligence Unit, Shanghai, as it was known at various times, is believed to be the Navy's first shore-based intercept station..$^{54}$

Due to equipment and personnel shortages, the

\footnotetext{
${ }^{51}$ 3d Brigade Proposed Forward Echelon, Plan II, March 1928, draft B-2 section transmitted to Headquarters Intelligence Section by Maj Earl C Long, box 1, Division of Operations and Training, Intelligence Section, General Correspondence, 1919-1939, RG 127, NARA.

${ }^{52}$ 3d Brigade Proposed Forward Echelon, Plan II.

53 Camp, "Listening to the Enemy."

54 "Security Group in China, 1928 through 1945," Cryptolog 7, no. 2 (Winter 1986): pull-out supplement, A-6.
} 
station in Shanghai was closed from 1929 to 1935 . During this period, Marine Corps intercept operators worked in the Beijing station. However, by the mid1930s, it was decided to close the station in Beijing, effective 28 July 1935.55 At that point, the Shanghai radio security station at $4^{\text {th }}$ Marines was reestablished, operating from 1935 to 1940.

On 5 March 1932, the chief of naval operations forwarded a letter to the commanding officer of Marine Detachment, Beijing, commending "the excellent work and progressive development of the Intercept Station, Peiping, for the past four years, and especially during the past six months." ${ }^{56}$ A letter dated 26 October 1935 discussing Marine Corps intercept operators at the Beijing station noted nine enlisted Marines assigned in 1932 and 1933 and eight Marines assigned in 1934. ${ }^{57}$ Unfortunately, the Navy had asked for 20 Marine Corps intercept operators, and these lower numbers led to the 1935 closing of the Beijing station. The Marine Corps provided the officer-in-charge for the reactivated Shanghai intercept station with Captain Shelton C. Zern (1935-38), Captain Kenneth H. Cornell (1937-39), and Captain Alva B. Lasswell (1939-40), each serving as the $4^{\text {th }}$ Marines assistant communications officer, the station officer-in-charge's official cover. $^{5^{8}}$

In the 1920 and well into the 1930s, Navy fleet commanders also had small staffs and often had the fleet Marine officer serve as the fleet intelligence officer. For example, Brigadier General Dion Williams served as fleet Marine officer of the U.S. Atlantic Fleet and fleet intelligence officer of that fleet from December 1907 to October 1909.59

In July 1937, war between China and Japan erupted in earnest. Admiral Harry E. Yarnell, commander of the Asiatic Fleet, moved his flagship, the heavy cruiser USS Augusta (CA 31) to Shanghai. Admiral Yarnell met regularly with the U.S. consul general and Colonel Charles F. B. Price, the commanding officer

\footnotetext{
55 "Security Group in China, 1928 through 1945," A-4.

${ }^{56}$ Camp, "Listening to the Enemy," 41.

57 "Security Group in China, 1928 through 1945," A-4.

${ }^{5}$ Camp, "Listening to the Enemy."

59 "Military History of BGen Dion Williams."
}

of 4 th Marines. ${ }^{60}$ The fleet intelligence officer of the Asiatic Fleet, Lieutenant Henry H. Smith-Hutton, was a Japanese linguist, while the 4th Marines' R-2, Captain Ronald Aubry Boone, was a Chinese linguist. Together, they were able to keep the Asiatic Fleet and

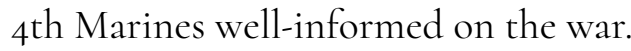

Boone's assistant R-2 was First Lieutenant Victor H. Krulak, who would retire as a lieutenant general and commanding general of the Fleet Marine Force Pacific. Krulak was able to observe Japanese offensive operations on the Yangtze River during 1937 and wrote an intelligence information report on Japanese landing craft titled Japanese Assault Landing Operations: Yangtze Delta Campaign, 1937. The report highlighted Japanese boats "which were obviously designed to negotiate surf and shallow beach landings." The report went on to note "the overhanging square bow of the Type 'A' boat is hinged about 18 inches above the water line so that the entire bow structure can be lowered, thus making a landing ramp for troops and rolling vehicles." ${ }^{2}$ Since this was a problem that had vexed Marines for some time, upon returning to the United States, Krulak followed his report through ONI to the Bureau of Ships to see what was being done with the information. The staff in the bureau thought the report had reversed the labeling of the bow and the stern and so had ignored it. Once Krulak explained that the photos were labeled properly, the staff became much more interested in his report. ${ }^{63}$

The brigades in Haiti/Dominican Republic and Nicaragua appear less interesting from an intelligence perspective than the $3 \mathrm{~d}$ Brigade in China, except for aviation support. Lieutenant Colonel Kenneth J. Clifford noted in his work Progress and Purpose, "Marine air served in Santo Domingo from February 1919 until July 1924, in Haiti from March 1919 to August 1934,

\footnotetext{
${ }^{60}$ Packard, A Century of U.S. Naval Intelligence, 393.

${ }^{61}$ 1stLt Victor H. Krulak, Japanese Assault Landing Operations: Yangtze Delta Campaign, 1937 (Washington, DC: U.S. Marine Corps, 1937) as reproduced in LtCol John J. Guenther, The Transformation and Professionalization of Marine Corps Intelligence (Quantico, VA: Marine Corps Intelligence Activity, 2017), 86.

${ }^{62}$ Krulak, Japanese Landing Operations, 94.

${ }_{63}$ Guenther, The Transformation and Professionalization of Marine Corps Intelligence, 86.
} 
and in Nicaragua from 1927 to $1933 .{ }^{.64}$ The Marine Corps established the School of Aerial Observation at Quantico during mid-1926 in response to early lessons learned by Marines in the Caribbean, where Marine Observation Squadron 9 was stationed in Haiti and Aviation Squadron, ad Brigade, was stationed in Nicaragua. The history of Marine Corps Base Quantico notes that "Marine aviators conducted two extensive courses at the School of Aerial Observation at Quantico during 1926, and students worked directly with the 5th Regiment to perfect air-ground coordination." ${ }^{65}$

We close this section on the Marine brigades with an anecdote on the relations between $3 \mathrm{~d}$ Marine Brigade and the Asiatic Fleet. The $3 d$ Marine Brigade was under command of the Asiatic Fleet, and while some equipment and supplies were procured centrally by the Headquarters Quartermaster Department, certain Navy funds were managed by the fleet. In November 1927, the 3d Brigade B-2, Major Long, sent a request to the Asiatic Fleet for additional "intelligence funds" for paid agents and translators. On 14 December 1927 , Rear Admiral Mark L. Bristol, commander in chief of the Asiatic Fleet, wrote to the commanding general of $3 \mathrm{~d}$ Brigade, "It is the Commander in Chief's policy not to employ paid agents. However, he would like to have the Commanding General's comments regarding this matter." ${ }^{66}$ Brigadier General Butler replied on 29 December 1927 that he agreed "information from paid agents cannot be relied upon in its entirety." However, he went on, "with a system such as the Brigade Intelligence Section has for checking the information these paid agents submit, this is a source of information that we cannot afford to neglect for the small amount

\footnotetext{
${ }^{64}$ LtCol Kenneth J. Clifford, Progress and Purpose: A Developmental History of the U.S. Marine Corps, 1900-1970 (Washington, DC: History and Museums Division, Headquarters Marine Corps, 1973), 38.

${ }^{65}$ LtCol Charles A. Fleming, Capt Robin L. Austin, and Capt Charles A. Braley III, Quantico: Crossroads of the Marine Corps (Washington, DC: History and Museums Division, Headquarters Marine Corps, 1978), 52. ${ }^{66}$ Asiatic Fleet Cmdr in Chief letter to CG 3d Brigade, Subj: "Intelligence Funds," 14 December 1927, box 1, Division of Operations and Training, Intelligence Section, General Correspondence, 1919-1939, RG 127 , NARA.
}

of money involved." ${ }^{17}$ This exchange ended well, but it points to one reason the Major General Commandant had been pressing for new policy and doctrine on the command relationships between fleet and Marine commanders ashore.

\section{Creation of the Fleet Marine Force}

Major General Lejeune became the Major General Commandant on 1 July 1920 . Having commanded the 4th Marines and 2d Army Division in World War I, Lejeune felt the Marine Corps needed revised policy and doctrine for command and control of large Marine formations ashore. In 1916, he wrote, "All, I believe, will agree that our training as an Advance Base organization, both as a mobile and as a fixed defense force, will best fit us for any or all of these roles [seize, fortify, and hold a port], and that such training should, therefore, be adopted as our special peace mission." ${ }^{68}$

In February 1922, Major General Lejeune sent a memorandum to the General Board of the Navy stating, "The primary war mission of the Marine Corps is to supply a mobile force to accompany the Fleet for operations ashore in support of the Fleet."69 Clearly, this would drive a need for standing Marine brigades with organizations and equipment to enable them to be a "mobile force," defined command relationships during "operations ashore," and related technical support capabilities such as intelligence. Fleet maneuvers were conducted in the 1920 s that included seizing and defending advance bases with the Marine Corps exercise force designated the Marine Corps Expeditionary Force (MCEF).

Major General Lejeune retired in 1929, and it

\footnotetext{
${ }^{67}$ CG 3d Brigade letter to the Asiatic Fleet Commander in Chief, Subj: "Intelligence Funds," 29 December 1927, box 1, Division of Operations and Training, Intelligence Section, General Correspondence, 1919-1939, RG 127 , NARA. The letter requested $\$ 500$ per month in intelligence funds, of which $\$ 200$ was for paid agents.

${ }^{68}$ John A. Lejeune, "The Mobile Defense of Advance Bases by the Marine Corps," Marine Corps Gazette 1, no. 1 (March 1916): 2.

${ }^{69}$ MajGen Cmdt memo to General Board dated 11 February 1922, Subject: Future Policy for the Marine Corps as Influenced by the Conference on the Limitation of Armament (Record 432) as cited in Clifford, Progress and Purpose, 30.
} 
was not until Major General Ben H. Fuller became Commandant the following year that the pace of development of Lejeune's envisioned mobile force would accelerate. In 1933, Major General John H. Russell, assistant to the Commandant, recommended dropping the term expeditionary force and using a term that better conveyed the role of Marines within the fleet: the Fleet Marine Force (FMF). On 7 December 1933, the secretary of the Navy created the FMF by issuing Navy Department General Order 241. ${ }^{\circ}$

Marine Corps Schools (MCS) at Quantico had started work in 1931 on a tentative text to be titled Marine Corps Landing Operations. Progress had been slow, and knowing that the approval of the FMF was imminent, in November 1933 classes were cancelled and MCS instructors and students prepared a detailed outline of the manual. By June 1934, the Tentative Manual for Landing Operations was available in mimeograph form for use by the 1934-35 school year's classes..$^{71}$ The manual was revised and reproduced in various forms annually until 1939, when the definitive version was issued as Landing Operations Doctrine, United States Navy 1938, Fleet Training Publication 167 (FTP-167)..$^{22}$ Landing Operations Doctrine, United States Navy 1938 was used with minor changes through World War II.

Landing Operations Doctrine, United States Navy 1938 contained dozens of references to intelligence and reconnaissance. It emphasized the importance of a detailed intelligence plan that compared data required for the mission to the data available on the area of operations and development of a plan for collecting the additional information needed to conduct the operation. This in turn would determine the "size, composition, and tasks of the reconnaissance force dispatched to the theater of operations." "73 Chapter 4, "Ship to Shore Movement," offers a list of reasons to use rubber landing craft, one of which was "landing of intelligence agents." ${ }^{4}$ Chapter 2, "Task Organization,"

\footnotetext{
$7^{\circ}$ Millett, In Many A Strife, 113.

${ }^{71}$ Clifford, Progress and Purpose, 140

${ }^{72}$ Landing Operations Doctrine, United States Navy 1938, FTP-167 (Washington, DC: Office of Naval Operations, Division of Fleet Training, 1938).

${ }^{73}$ Landing Operations Doctrine, United States Navy 1938, 6.

${ }^{74}$ Landing Operations Doctrine, United States Navy 1938, 61.
}

recommended creating a reconnaissance group and noted "photographs and panoramic sketches executed by surface craft or submarines, and oblique aerial photographs from seaward will be a great assistance" to boat group, fire support groups, and troop commanders. ${ }^{75}$

On 18 December 1934, Marine Corps General Order No. 84 was issued designating the 1st Marine Brigade at Quantico as the first FMF brigade headquarters, with "the Fifth Marines constituting the nucleus on the East Coast and the Sixth Marines on the West Coast." ${ }^{6}$ Major General Lejeune's former G-2, Ralph Keyser, wrote, "The establishment of the Fleet Marine Force and the inclusion of a force of Marines as an integral part of the United States Fleet organization should give great satisfaction to those interested in the welfare of the Marine Corps." 77

\section{Pre-World War II Reorganization of Headquarters Marine Corps}

On 21 April 1939, Major General Thomas Holcomb issued Headquarters Memorandum No. 1-1939 on staff organization and procedures, in which the Division of Operations and Training was redesignated the Division of Plans and Policies. ${ }^{78}$ According to A Brief History of Marine Corp Staff Organization,

popularly known as "Pots and Pans," the new Division retained the same subdivisions as the old with the standard number designations of a general or executive staff, but designated "M" rather than "G." Under the supervision of a Director, the Division contained the standard M-l, Personnel; $\mathrm{M}-2$, Intelligence; M-3, Training; and $\mathrm{M}-4$, Supply and Equipment Sections

\footnotetext{
75 Landing Operations Doctrine, United States Navy 1938, 33.

${ }_{76}$ "Transition of the Fleet Marine Force," Marine Corps Gazette 20, no. 1 (February 1936): 7 .

77 LtCol Ralph S. Keyser, "The Fleet Marine Force," Marine Corps Gazette 18, no. 1 (February 1934): 51.

$7^{8}$ T. Holcomb, Headquarters Memorandum No. 1-1939, Subject: Staff Organization and Procedure, Headquarters, U.S. Marine Corps, 21 April 1939, RG 127, NARA.
} 


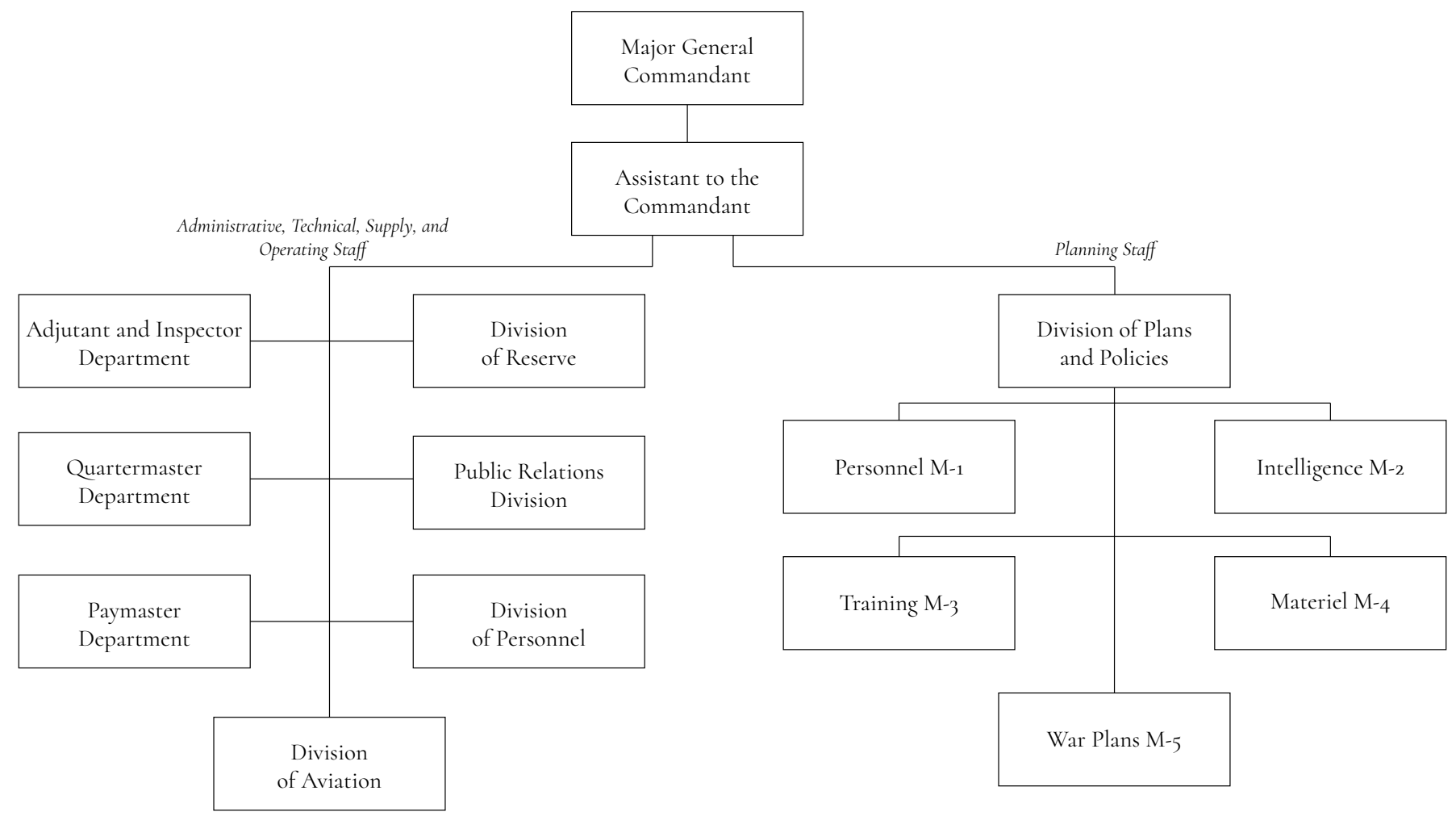

A Brief History of Headquarters Marine Corps Staff Organization, adapted by MCU Press Table of organization, Headquarters Marine Corps, 1 August 1941.

and an M-5, War Plans Section, which was to be abolished in the fall of 1941, with $\mathrm{M}-5$ functions being absorbed by $\mathrm{M}-3 .{ }^{79}$

The Division of Plans and Policies did not have the authority to execute policy, only to formulate recommendations to the Major General Commandant, who in turn would issue orders to the administrative staff.

Mark Stout has written on the importance of the World War I experience to the creation of an intelligence community in the United States, noting, "The standard origin myth of modern American intelligence has the period from World War II to the passage of the National Security Act in 1947 as the seminal period. ... It is clear that many of the artifacts, val-

79 Condit, Johnstone, and Nargele, A Brief History of Marine Corps Staff Organization, 17 . ues, and assumptions that exist in today's Intelligence Community date back to World War I." ${ }^{80}$

The first director of the M-2 is believed to be Major David A. Stafford. An article published on the occasion of Brigadier General Stafford's retirement noted that "from 1935 to 1940 he served variously as a 'sea soldier' aboard the 'USS West Virginia,' and as officer in charge of intelligence in the Division of Plans and Polices at Marine Corps Headquarters in Washington, D.C." ${ }^{\prime 1}$

Intelligence Marines have traditionally observed the Headquarters reorganization of April 1939 and creation of the M-2 as the birthdate of Marine Corps intelligence. With all deference to the trailblazing work of Major Stafford and the officers who succeeded him

${ }^{80}$ Stout, "World War I and the Birth of American Intelligence Culture," 378 .

${ }_{81}$ "Gen Stafford Retired from Marines June 30," Press-Republican (Plattsburgh, NY), 21 July 1949, 3 . 
throughout the World War II era, given the facts outlined above, the true formal birth of Marine Corps intelligence occurred on 1 December 1920 with Lejeune's establishment of the Military Intelligence Section in the Division of Operations and Training. It seems on 1 December 2020, Intelligence Marines around the world should be saying to each other, "Happy 1ooth Birthday, Marine!"

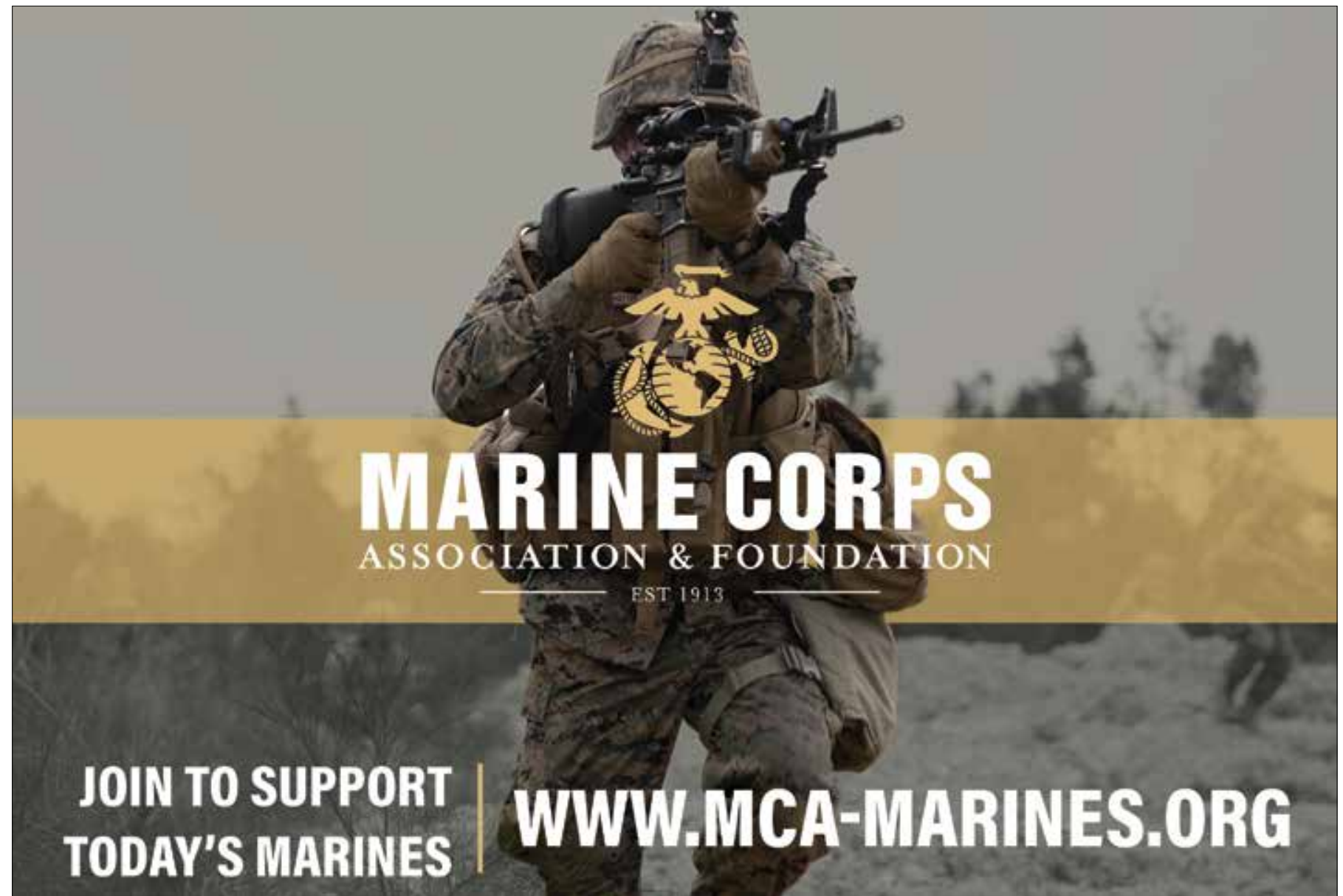




\title{
"Tree Hugging Work" \\ THE SHIFTING ATTITUDES AND PRACTICES \\ OF THE U.S. MARINE CORPS TOWARD PEACE OPERATIONS IN THE $1990 \mathrm{~S}$
}

by Mary Elizabeth Walters, PhD

\begin{abstract}
In the post-Cold War decade, the Marine Corps gradually, if inconsistently, incorporated peace operations-what one Marine officer characterized as "tree hugging work"-as one of its core missions. Starting with Operation Provide Comfort in northern Iraq in 1991, followed by a host of missions around the world and culminating in the 1999 Kosovo War, the Marine Corps became increasingly involved in peace operations. Simultaneously, Marine Corps doctrine underwent a dramatic shift between 1989 and 2001, ultimately arguing that Marines were the best branch of the military to conduct peace operations. This article examines the development and interrelationship of doctrine, training, and missions relating to peace operations during the 1990 . To capture how a decade of doctrinal development, training, and missions reshaped the Marine Corps' practice of peace operations, this article focuses on two influential missions that bookended the decade: Operation Provide Comfort in northern Iraq in 1991 and the Kosovo Force (KFOR) peacekeeping operation that followed the 1999 Kosovo War.
\end{abstract}

Keywords: peace operations, humanitarian operations, migrant assistance operations, natural disasters, Operation Provide Comfort, Kosovo Force, Kosovo War, Persian Gulf War, Marine Corps doctrine, doctrinal changes, doctrinal development, operations other than war, OOTW, military operations other than war, MOOTW, Kurdish refugees, Albanian refugees, three block war, strategic corporal, nation assistance

L ooking at a field of tents filled with ethnic Albanian refugees from Kosovo in 1999, a young Marine officer griped that he wished the "tree hugging work" of humanitarian aid had been left to the Air Force. A corporal complained, "I don't know why we're going through all the trouble building these refugee camps. It seems like it would be a whole lot easier to just go into Kosovo and take their old homes

Mary Elizabeth Walters is an assistant professor in the Department of History at Kansas State University in Manhattan. She received a master of arts and a doctorate in history from the University of North Carolina at Chapel Hill.

https://doi.org/10.35318/mch.2019050204 back." This resistance did not come from a lack of caring, but from a belief that the Marines could provide more effective assistance by simply halting the campaign of ethnic cleansing. These two Marines reflect the primary identity of the U.S. Marine Corps: "fierce combat prowess." Yet during the course of the 199os, an alternate strand of Marine Corps culture developed that perceived the tree hugging work of peace operations as a core mission of the Marine Corps.

\footnotetext{
${ }^{1}$ Jon R. Anderson, "Marines Work on Three Fronts," Stars and Stripes (Europe), 6 May 1999, item 54, in K. J. Glueck, 26th Marine Expeditionary Unit (MEU) Command Chronology (ComdC), 1 January 1999-31 July 1999, file 5/1732, Part 3, secs. 3-54-2, Archives Branch, Marine Corps History Division, Quantico, VA.

${ }^{2}$ Paula Holmes-Eber, Culture in Conflict: Irregular Warfare, Culture Policy, and the Marine Corps (Stanford, CA: Stanford University Press, 2014), 54.
} 
In the post-Cold War decade, the Marine Corps gradually, if inconsistently, incorporated peace operations as one of its core missions. Starting with Operation Provide Comfort in northern Iraq in 1991, followed by a host of missions around the world and culminating in the 1999 Kosovo War, the Marine Corps became increasingly involved in peace operations. Simultaneously, Marine Corps doctrine underwent a dramatic shift between 1989 and 2001, ultimately arguing that Marines were the best branch of the military to conduct peace operations. This article examines the development and interrelationship of doctrine, training, and missions relating to peace operations during the 1990s. It traces the Marine Corps' changing approach to peace operations in the 1990 by examining two sets of doctrine, the Fleet Marine Force Manual (FMFM) series published between 1989-91 and the Marine Corps Doctrinal Publications (MCDPs) published in 1997 and 1998. The changes in doctrine during this period both reflect, and were driven by, the changing nature of missions. During the 1990s, Marines deployed on more than 70 distinct missions that fell into the broad category of peace operations. ${ }^{3}$ Marines assisted with migrant assistance operations, provided humanitarian relief in the face of natural disasters around the world, conducted peacekeeping operations, and rescued civilians from unstable areas. ${ }^{4}$ These are just a sampling of the wide range of places and types of peace operations on which Marines deployed, but collectively they created an environment that began to normalize peace opera-

\footnotetext{
3 This figure was compiled based on "Marine Corps Operations Since 1776," Historical Reference Branch, Marine Corps History Division, Quantico, VA.

${ }^{4}$ Literature on peace operations in the 1990 os-much less more recent operations-is very much a developing field, particularly among historians, though operations in Somalia have gotten more attention. For those interested in operations not covered in this article, the following works are excellent starting points: Robert C. DiPrizio, Armed Humanitarians: U.S. Interventions from Northern Iraq to Kosovo (Baltimore, MD: Johns Hopkins University Press, 2002); Theo Farrell, "Sliding into War: The Somalia Imbroglio and US Army Peace Operations Doctrine," International Peacekeeping 2, no. 2 (Summer 1995), 194-214, https://doi .org/10.1080/13533319508413551; Philippe R. Girard, Clinton in Haiti: The 1994 U.S. Intervention in Haiti (New York: Palgrave Macmillan, 2004); John L. Hirsch and Robert B. Oakley, Somalia and Operation Restore Hope: Reflections on Peacemaking and Peacekeeping (Washington, DC: United
}

tions as important for the Marine Corps. To capture how a decade of doctrinal development, training, and missions reshaped the Marine Corps' practice of peace operations, this article focuses on two influential missions that bookended the decade: Operation Provide Comfort in northern Iraq in 1991 and the Kosovo Force (KFOR) peacekeeping operation that followed the 1999 Kosovo War.

Before continuing, a brief discussion of terminology is warranted. As Paul F. Diehl wryly observes, "Discussions of peace operations are notorious for their conceptual muddles." During the 1990s, terms and their meanings related to peace operations constantly shifted, within both military and academic circles. These included operations other than war (OOTW), military operations other than war (MOOTW), peacekeeping, peace enforcement, peacemaking, peacebuilding, national assistance, and humanitarian assistance. Further complicating matters, one operation might shift between subsets of peace operations. While these terms have their uses, and may relate to specific United Nations (UN) Charter chapters authorizing a mission or to rules of engagement, focusing on shifting terms distracts from broader trends in Marine Corps culture and doctrine in the post-Cold War period. Therefore, throughout this article the term peace operation is used as an umbrella expression to refer to a host of tasks and missions.

\section{Warfighting, FMFM 1}

As Marines entered the wave of peace operations of the 1990s, they lacked a guiding doctrine. During the 1980 , Marines participated in several small wars and

States Institute of Peace, 1995); Michael G. MacKinnon, The Evolution of US Peacekeeping Policy Under Clinton: A Fairweather Friend? (London: Frank Cass, 200o); Paul A. McCarthy, Operation Sea Angel: A Case Study (Santa Monica, CA: Rand, 1994); Col Dennis P. Mroczkowski, Restoring Hope: In Somalia with the Unified Task Force, 1992-1993 (Washington, DC: Marine Corps History Division, 2005); Walter S. Poole, The Effort to Save Somalia, August 1992-March 1994 (Washington, DC: Joint History Office, Office of the Chairman of the Joint Chiefs of Staff, 2005); Col Nicholas E. Reynolds (USMCR), A Skillful Show of Strength: U.S. Marines in the Caribbean, 1991-1996 (Washington, DC: History and Museums Division, Headquarters Marine Corps, 2003); Charles R. Smith, Angels from the Sea: Relief Operations in Bangladesh, 1991 (Washington, DC: History and Museums Division, Headquarters Marine Corps, 1995).

5 Paul F. Diehl, Peace Operations (Cambridge, UK: Polity Press, 2008), 3. 
counterinsurgencies, even a peacekeeping operation in Lebanon, but the FMFM revisions between 1989 and 1991 remained combat oriented. The FMFM revisions, particularly to Warfighting, sought to justify the utility of the Marine Corps in the Cold War while also shying away from the concept of small wars. Although the Marine Corps pioneered U.S. military thinking on small wars and counterinsurgency in the early twentieth century, formalizing many of these concepts in the 1940 Small Wars Manual, the Vietnam War and the 1983 Marine barracks bombings in Beirut soured the Corps' attitudes toward these murky and complex missions. ${ }^{6}$ Yet, as Nicholas J. Schlosser argues, Marine divisions as structured in the 1970 and 1980 sould "likely be wiped out" if deployed in Europe against the Soviet Union. Warfighting, published in 1989, answered this problem by embracing the concept of maneuver warfare, focusing on "speed, maneuver, and mechanization over heavy armor and firepower."

Warfighting argues that "maneuver warfare is a warfighting philosophy that seeks to shatter the enemy's cohesion through a series of rapid, violent, and unexpected actions which create a turbulent and rapidly deteriorating situation with which he cannot cope." The aim is not the physical destruction of the enemy, but the destruction of their morale and ability to fight. This emphasis on morale created a niche for Marine expeditionary forces to "win quickly against a larger foe on his home soil." The doctrine explains that firepower remains important not to "incrementally" degrade enemy capability, but to "shatter the enemy's cohesion" with the "ultimate aim" of "panic and paralysis." Violence should therefore be focused at specific vulnerabilities and Marines must be prepared to decisively exploit weaknesses. ${ }^{10}$ Notably, Warfighting's discussion of enemy morale and how to weaken it lacks depth. Understanding the opponent's culture,

\footnotetext{
${ }^{6}$ Keith B. Bickel, Mars Learning: The Marine Corps Development of Small Wars Doctrine, 1915-1940 (Boulder, CO: Westview Press, 2001), xi.

7 Nicholas J. Schlosser, U.S. Marines and Irregular Warfare Training and Education, 2000-2010 (Quantico, VA: Marine Corps History Division, 2015), 18, 19 .

${ }^{8}$ Warfighting, FMFM 1 (Washington, DC: Headquarters Marine Corps, 1989), 59 .

9 Warfighting, 58.

${ }^{10}$ Warfighting, 59-61.
}

much less the local civilian population, does not feature in the doctrine at all.

The closest the FMFM series came to incorporating peace operations is a vague discussion of low intensity conflict. The 29th Commandant of the Marine Corps, General Alfred M. Gray Jr., envisioned these conflicts as being predominantly in "the revolutionary warfare environment" and argued that "military force is not the dominant characteristic of the struggle but is only one of several components of national power, all of which must be fully coordinated with one another." ${ }^{11}$ Campaigning, FMFM 1-1, argues that the limited political aims of low intensity conflicts are more difficult to convert "into military conditions, as illustrated by the questionable military mission of Marine forces in Beirut 1982-84."12 Despite that warning, Campaigning offers no guidance on operating in low intensity conflicts. The "means" of campaigning are identified as "tactical results-be they victories, losses, or draws." ${ }^{\prime 3}$ Peace operations' place in this schema is left unaddressed. Furthermore, Tactics, FMFM 1-3, abandons the pretense of addressing low intensity conflict; even the phrase is absent. At the tactical level, maneuver warfare "is the combination of movement and fire to gain an advantage on the enemy. The focus of effort ties together all the maneuvering and points it at the enemy so that Marines will win." ${ }^{14}$ Without a substantive discussion of low intensity warfare, much less peace operations, Marines' actions in the 1990 os were based on ad hoc decisions and cultural assumptions.

\section{Operation Provide Comfort, 1991}

This doctrinal oversight proved to be no minor issue. According to one tally, the U.S. military deployed more than 200 peace operations between 1989 and 2000. ${ }^{15}$ Marines experienced their first humanitarian

\footnotetext{
${ }^{11}$ Campaigning, FMFM 1-1 (Washington, DC: Headquarters Marine Corps, 1990), ii.

${ }^{12}$ Campaigning, 35

${ }_{13}$ Campaigning, 7 .

${ }^{14}$ Tactics, FMFM 1-3 (Washington, DC: Headquarters Marine Corps, 1991), 18, emphasis original.

${ }^{15}$ Frank N. Schubert, Other than War: The American Military Experience and Operations in the Post-Cold War Decade (Washington, DC: Joint History Office, Office of the Chairman of the Joint Chiefs of Staff, 2013), 1, 2
} 
and development-heavy peace operation in the wake of the Persian Gulf War. Following a failed revolt in early April 1991, more than 500,00o Kurds were stranded in "the dubious safety" of the mountains between Turkey and Iraq, while another million fled to Iran. ${ }^{16}$

International attention focused on the Kurdish refugees trapped in the mountains along the border of Turkey and Iraq. Three main factors made helping these refugees difficult. First, the Kurdish refugee crisis developed rapidly, but UN agencies and nongovernmental organizations (NGOs) typically need time to scale up their operations. Second, the remote and difficult terrain of the mountains may have provided the Kurds with some protection, but it also created challenges in delivering humanitarian aid. Even the U.S. military faced logistical problems operating in the mountains, much less civilian NGOs. Third, UN humanitarian organizations were in a moment of uncertainty as they sought to find their footing in the post-Cold War world. The UN High Commissioner for Refugees (UNHCR), for example, was reframing itself as an operations-oriented humanitarian agency, rather than a refugee agency that relied on operational partners. This crisis represents the first major test of the new UNHCR, and High Commissioner Sadako Ogata was initially reluctant to assume overall humanitarian responsibility. Ogata was keenly aware that the UNHCR had a very limited emergency response capability. ${ }^{17}$ Even so, advance teams from the UNHCR attempted to provide coordination, but as Gordon W. Rudd argues, "they had little resources to offer and little experience in managing relief efforts of this nature ... and NGOs paid little attention to them." ${ }^{18}$ As the crisis developed, the UNHCR assumed the role of the official leader of humanitarian assistance, even

\footnotetext{
${ }^{16}$ Gordon W. Rudd, Humanitarian Intervention: Assisting the Iraqi Kurds in Operation Provide Comfort, 1991 (Washington, DC: Department of the Army, 2004), 35, 36; and LtCol Ronald J. Brown (USMCR), Humanitarian Operations in Northern Iraq, 1991: With Marines in Operation Provide Comfort (Washington, DC: History and Museums Division, Headquarters Marine Corps, 1995), 1, 2.

${ }^{17}$ Anne Hammerstad provides a compelling narrative of the transformation of the UNHCR in the 1990s in The Rise and Decline of a Global Security Actor: UNHCR, Refugee Protection, and Security (Oxford, UK: Oxford University Press, 2014), 75-80, 181, 182.

${ }^{18}$ Rudd, Humanitarian Intervention, 75.
}

as some $200 \mathrm{NGOs}$ and allied military forces carried out much of the work. ${ }^{19}$ As a result of these three factors, the U.S. military found itself the primary coordinator of humanitarian aid and the primary logistics provider.

With freezing temperatures and little water or food, conditions in the mountains soon turned deadly. ${ }^{20}$ In an after action report notable for its vivid imagery, Colonel James L. Jones and Staff Sergeant L. J. Tibbetts described the paths from Iraq as littered with abandoned possessions that no longer served any utility; broken down cars, appliances, family heirlooms, furniture, suitcases that had become too heavy to carry, and tragically, people who could not withstand the rigors of the march and simply stopped fighting, to wait for death to end their suffering. ${ }^{21}$

Doctors Without Borders described the situation as a "medical apocalypse" and at the height of the crisis humanitarian workers reported that roughly 1,5 oo refugees were dying every day. While the freezing temperatures provided an immediate health hazard, warming temperatures would provide no relief. The little water Kurdish refugees had access to came from small mountain streams, which would go dry in summer. Operation Provide Comfort, the multinational military response to the refugee crisis, lasted from 7 April to 15 July 1991. Initially, the U.S. Army's 1oth Special Forces Group (Airborne) (1oth SFG [A]),

\footnotetext{
${ }^{19}$ Hammerstad, The Rise and Decline of a Global Security Actor, 184 .

${ }^{20}$ Brown, Humanitarian Operations in Northern Iraq, 1, 2.

${ }^{21} \mathrm{Col}$ J. L. Jones and SSgt L. J. Tibbetts, "Operation Provide ComfortThe Capstone," in J. C. Hardee, 2/8 Battalion Landing Team (BLT 2/8) Command Chronology (ComdC), 1 July 1991-31 December 1991, file 2/1641, Archives Branch, Marine Corps History Division, Quantico, VA. ${ }^{22}$ Brown, Humanitarian Operations in Northern Iraq, 1, 2. It is important to note that there is no consensus on how many ethnic Kurds died during this period. A study by the Centers for Disease Control and Prevention (CDC) found that "death rates peaked during April 13-26," before declining as military forces delivered aid. However, the CDC estimated that the minimum total death toll while refugees were "camped on the Turkey-Iraq border" was 6,700, which casts some doubt on the estimate from Doctors Without Borders. CDC, "Public Health Consequences of Acute Displacement of Iraqi Citizens-March-May 1991," Journal of the American Medical Association 266, no. 5 (August 1991): 633-34.
} 
which provided the foundation for Joint Task Force Alpha, led emergency assistance to the makeshift mountain camps of refugees. When the 1oth SFG (A) arrived, they identified 12 refugee camps in the mountains, each with a population averaging 45 ,ooo. The 1oth SFG (A) identified and organized camps, found the best drop zones, provided medical assistance, and planned for security requirements. ${ }^{23}$

As the 10th SFG (A) provided humanitarian assistance to Kurdish refugees in the mountains along the Turkish-Iraqi border, the 24th Marine Expeditionary Unit (24th MEU) made an amphibious assault on Sardinia as part of the Philippines Amphibious Land Exercise (PHIBLEX) 1-91. Just 12 hours into the mock assault on 9 April, however, a "hasty backload was ordered" so the 24th MEU could join Operation Provide Comfort. ${ }^{24}$ Details on what the 24th MEU's involvement would entail remained unclear. The Battalion Landing Team, 2d Battalion, 8th Marines (BLT 2/8), command chronology scathingly noted that "the lack of specific details provided by the alert and execute orders made this task [and creating a detailed mission analysis] difficult at best." As late as 11 April, as lead elements arrived in Turkey, the MEU was still relying on guesswork in preparing for a humanitarian relief operation. ${ }^{25}$ On 14 April, the 24th MEU offloaded at Turkey's port of Iskenderun and began a $676-\mathrm{km}$ trek to Silopi, near the Turkey-Iraq border, while they waited for final orders. ${ }^{26}$

As most of the 24th MEU disembarked and moved to their staging base in Silopi, the MEU's Marine Medium Helicopter Squadron 264 (HMM 264) Black Knights flew ahead and temporarily joined Joint Task Force Alpha on 15 April. During the course of the following two weeks, the Black Knights flew more than 1,ooo hours and delivered 1 million-plus pounds of aid to refugees in inaccessible areas of the moun-

\footnotetext{
${ }^{23}$ Jones and Tibbetts, "Operation Provide Comfort."

${ }^{24}$ T. L. Corwin, BLT 2/8 ComdC, 1 January 1991-30 June 1991, file 1/1641, Archives Branch, Marine Corps History Division, Quantico, VA.

${ }_{25}$ J. C. Hardee, 2/8 BLT ComdC, 1 July 1991-31 December 1991, file 2/1641, Archives Branch, Marine Corps History Division, Quantico, VA.

${ }^{26}$ Hardee, 2/8 BLT ComdC, 1 July 1991-31 December 1991.
}

tains. ${ }^{27}$ For the Black Knights' commander, Lieutenant Colonel Joseph A. Byrtus Jr., the camp at Isikveren, Turkey, with its 80 ,ooo refugees was a sight he would not forget: "A pall of smoke from thousands of small cooking fires hung perhaps zo feet above the camp in a thin, neat layer." As his three Sikorsky CH-53E Super Stallion helicopters approached, Byrtus realized that there was no space to land due to the camp's overcrowding. A small area was cleared by the helicopter's rotor wash, as people "ran . . f followed by their tents and meager belongings." As the crew hurried to unload humanitarian supplies, "a crowd of 10,00o or more rushed the aircraft from all sides in a desperate dash for food and water." ${ }^{28}$

Finally, on 19 April, Joint Task Force Bravo was established, centered on the 24th MEU, and ordered to take charge of "security operations in northern Iraq" and assist Kurdish refugees' return to Iraq. On 20 April at 0100, the 24th MEU conducted "a heliborne insertion" into the outskirts of the city of Zakho, Iraq, $9.6 \mathrm{~km}$ south of the Turkish border. By this point, the city "was virtually empty of civilian inhabitants" as a result of intense fighting previously between the Kurdish Peshmerga and the Iraqi 36 th and 44th Infantry Divisions. The insertion of the 24 th MEU was carefully orchestrated in accordance with agreements made with Iraqi commanders at the border. Even so, Iraqi forces "seemed surprised by the sudden appearance of U.S. Marines." BLT 2/8's command chronology continued, "It became apparent after moving past Iraqi soldiers, that they did not want to fight or were too shocked to react." ${ }^{29}$ Colonel James L. Jones Jr. described his approach as "aggressive restraint." Iraqi forces were given every opportunity to pull back peacefully, but the Marines were not to back down if Iraqi forces tried to "bully" them..$^{30}$ This approach was put to the test on multiple occasions. At one point, a Marine reconnaissance unit found itself surrounded

\footnotetext{
${ }^{27}$ Jones and Tibbetts, "Operation Provide Comfort."

${ }^{28} \mathrm{LtCol}$ Joseph A. Byrtus Jr., "Into a Sea of Refugees: HMM-264," Marine Corps Gazette 75, no. 11 (November 1991): 101, as quoted in Jones, 24th MEU ComdC, 1 January 1991-30 June 1991.

${ }_{29}^{29}$ Hardee, 2/8 BLT Command Chronology, 1 July 1991-31 December 1991.

$3^{\circ}$ Brown, Humanitarian Operations in Northern Iraq, 55 .
} 
by roughly 50 Iraqi soldiers and needed a "hot" pickup. In a slight understatement, one member of the team told the Navy Times, "We had the fire power to hold them off if we had to, but it was pretty interesting for a while." ${ }^{11}$ The same day, an Army special forces team near Zakho faced a similar situation. ${ }^{22}$ On 26 April, the 24th MEU and the attached 45 Commando, Royal Marines, and 1st Amphibious Combat Group, Royal Netherlands Marine Corps, set up checkpoints controlling access to Zakho and conducted 24-hour patrols of the city and surrounding area. ${ }^{33}$ That night, the few Kurds who had already returned to Zakho "took joyfully to the streets." 34

While security operations were critical, the Marines simultaneously began humanitarian relief efforts. Even as Iraqi forces continued to occupy the high grounds around Zakho, by the end of the day on 20 April, Marine engineers had broken ground on the first of several refugee camps. The following day, engineers erected the first tents. By 22 April, the 24th MEU had baseline security in the immediate area, allowing for supply trucks from Silopi to reach Zakho. The BLT 2/8 command chronology emphasized the interrelationship between security and humanitarian efforts: "The overwhelming military presence by coalition forces demonstrated our resolve to establish and maintain a security zone for the Kurdish refugees." 35 The Marine Service Support Group 24 (MSSG 24) formed the core of the "largest Marine humanitarian effort in history" and did so while farther than $804 \mathrm{~km}$ from its sea base in Iskenderun, Turkey. ${ }^{36}$ The MSSG 24 reestablished infrastructure, provided humanitarian assistance, and led the construction of several tent camps, each housing roughly 25,0oo refugees. ${ }^{37}$ Construction efforts sought to "involve Kurdish leaders" in both selection and organization of the camps. $3^{8}$ As

\footnotetext{
${ }^{31}$ Jim Wolf, "Combat Danger Lurks in Relief Mission," Navy Times, 20 May 1991, in Jones, 24th MEU ComdC, 1 January 1991-30 June 1991.

${ }^{32}$ Wolfe, "Combat Danger Lurks in Relief Mission."

33 Jones, 24th MEU ComdC, 1 January 1991-30 June 1991.

34 Jones and Tibbetts, "Operation Provide Comfort."

35 Hardee, 2/8 BLT ComdC, 1 July 1991-31 December 1991.

${ }^{36}$ Brown, Humanitarian Operations in Northern Iraq, ii, 22, 87, 88.

37 Brown, Humanitarian Operations in Northern Iraq, 67, 77, 68, 87, 88.

$3^{38}$ Brown, Humanitarian Operations in Northern Iraq, 55, 9, 10.
}

more Kurdish refugees returned, additional Marines were diverted from security operations to humanitarian operations, such as expanding the refugee camps and dispensing food and aid. Among these Marines was Corporal Wade Sibley. As Sibley pounded tent stakes into what one reporter described as "a dank field of spring corn," Sibley reflected, "It's different all right. ... We're saving lives here and that's satisfying. ... But I wish we'd been here earlier. We felt kinda cheated not being in the war." As he drove home another tent post, Sibley grunted, "Since the war ended, you know, you wonder whether people notice." 39 Sibley and other Marines recognized the importance of the peace operation, but they longed for the type of war for which their training had prepared them.

In Zakho itself, MSSG 24 worked to make the refugee camps unnecessary by improving the city's living conditions. Engineer and maintenance teams repaired the city's power transmission facility, put in a new generator at the Zakho hospital, and repaired power and water plants. Medical and dental teams set up clinics that treated more than 2,ooo patients. ${ }^{40}$ Even once Marines outfitted the Zakho hospital with a new generator, it lacked more than a handful of nurses and had no medicine. Navy Commander O. C. Smith, the BLT 2/8 surgeon, described a six-year-old boy with second-and third-degree burns on more than 23 percent of his body: "His mother carried him down from the mountains, zo kilometers each way, every day. . . He should be in a hospital, but we do what we can for him here." ${ }^{11}$ Despite the limitations of Marine medical clinics, they were better than local alternatives.

By early May, a large number of Kurdish refugees had returned to Zakho. The Coalition security zone by that point stretched $159 \mathrm{~km}$ across northern Iraq. ${ }^{42}$ A clear indication that conditions had improved dramatically came when "Kurdish leaders began to

\footnotetext{
39 "A Different Kind of War: In Northern Iraq, the Marines Are Fighting to Save the Kurds," U.S. News and World Report 110, no. 17, 6 May 1991, in Jones, 24th MEU ComdC, 1 January 1991-30 June 1991.

${ }^{40}$ Brown, Humanitarian Operations in Northern Iraq, 67, 68, 87, 88.

${ }^{41}$ Sgt Jim Fitzgibbons, "Corpsmen Help to Ease the Kurds' Pain: Thousands Lie Sick or Dying in Mountains," Globe, 16 May 1991, 14A, in Jones, 24th MEU ComdC, 1 January 1991-30 June 1991.

${ }^{42}$ Jones and Tibbetts, "Operation Provide Comfort."
} 
complain about the suitability of [meals ready to eat] MREs as a food source." Even as the Kurds became pickier about their food, they called Marines a new nickname: "Food Soldiers." ${ }^{33}$ An even better indication of Kurds' growing sense of security came on 12 May, when a group of 1,5 oo Kurds felt comfortable holding a demonstration in downtown Zakho "calling for allies to move towards the city of Dahuk," $40 \mathrm{~km}$ south of the Coalition security zone. ${ }^{44}$ In addition to being home to 350,000 people before the crisis, Duhok was also the capital of the Duhok Province of northern Iraq, the same province from which most Kurdish refugees came. Duhok became not only a physical solution for Kurdish refugees who remained in the mountains and in refugee camps around Zakho, but also a test of American and Coalition commitment to the Kurds.

Negotiations soon began between American military forces, Iraqi forces, the United Nations, and several NGOs to allow for military and humanitarian forces to enter Duhok. Eventually, all parties agreed that Coalition forces could advance to a point $16 \mathrm{~km}$ north of Duhok, while Iraqi military forces and secret police would withdraw from Duhok to new positions $16 \mathrm{~km}$ south. Meanwhile, a small "humanitarian and logistical" Coalition military force would be allowed into Duhok accompanied by UN agencies and NGOs. Once these negotiations were completed, the 24th MEU began a carefully choreographed move south to Duhok. Lieutenant Colonel Tony L. Corwin explained that each "time the Company moved forward, it forced an Iraqi company ahead of it to withdraw." Once Marine units reached the agreed-upon $16-\mathrm{km}$ mark north of Duhok, they constructed roadblocks to prevent any unauthorized movement north toward Zakho. ${ }^{45}$ Final-

\footnotetext{
${ }^{43}$ Brown, Humanitarian Operations in Northern Iraq, 66, 91.

${ }^{44}$ Col James L. Jones, "Operation PROVIDE COMFORT: Humanitarian and Security Assistance in Northern Iraq," Marine Corps Gazette 75 , no. 11 (November 1991): 106, in Jones, 24th MEU ComdC, 1 January 199130 June 1991. Note that there are several ways to spell both the city and province of Duhok, including Dahuk, Dohuk, and Dihok. This article uses Duhok except for direct quotes.

${ }^{45}$ LtCol Tony L. Corwin, "BLT 2/8 Moves South," Marine Corps Gazette 75, no. 11 (November 1991): 106, in Jones, 24th MEU ComdC, 1 January 1991-30 June 1991.
}

ly, on zo May, a small military force and humanitarian workers moved into Duhok itself, exactly one month after the 24th MEU had entered Zakho. Almost immediately, Kurdish refugees began making their way back to Duhok. On 25 May, this refugee flow reached its peak with more than 55,ooo Kurds seeking temporary shelter at camps around Zakho as they traveled south. ${ }^{46}$

As the 24th MEU left Iraq in June after most Kurds had returned to their homes, the UNHCR reluctantly described Operation Provide Comfort as "a rare example of successful humanitarian intervention." ${ }^{\prime 4}$ Even while lamenting a "loss of innocence" among humanitarian workers who had been forced to work with Coalition military forces, Thomas G. Weiss argues, "Access by civilian humanitarians simply would not have been possible without the overwhelming allied military presence in April." ${ }^{28}$ Christine Gla, a French aid worker, agreed: "I don't choose to work with the military normally, but it's a special situation here. Without the Marines, the situation would be much more difficult." As Marines unloaded her supplies from Black Knight helicopters, Gla ruefully remarked that they were "Knights in Shining Armor." Colonel James Jones, commander of the 24th MEU, simply stated, "That's what we're here for."49 Although ambitious in the number of Kurdish refugees involved, Operation Provide Comfort was constrained in both time and geographic area. Even the move toward Duhok required intense negotiations with Iraqi leaders and relied on Iraqi permission. Furthermore, U.S. military planning emphasized efforts to stabilize the situation, provide quick logistical support, and then hand everything over to the United Nations, NGOs, and the Kurds. Despite clear successes, an after action report warned that the operation "demonstrated a need for a doctrinal publication" on peace opera-

\footnotetext{
${ }^{46}$ Jones and Tibbetts, "Operation Provide Comfort."

47 Thomas G. Weiss, "Military-Civilian Humanitarianism: The "Age of Innocence' Is Over," International Peacekeeping 2, no. 2 (1995): 165, https:// doi.org/10.1080/13533319508413549.

${ }^{48}$ Weiss, "Military-Civilian Humanitarianism," 165.

${ }^{49}$ Cpl E. H. Hughes, "Shining Knights Assist Relief Worker," in Hardee, 2/8 BLT ComdC, 1 July 1991-31 December 1991.
} 
tions. $^{5^{\circ}}$ The experience of simultaneously providing humanitarian assistance, separating warring groups, and conducting security operations significantly influenced thinking, doctrine, and training in the Marine Corps as the 1990 progressed.

\section{General Charles Krulak and Three Block War}

In the face of potential enlisted resistance to tree hugging peace operations, senior officers worked to justify why peace operations needed to be incorporated into deployments, training, and doctrine. In particular, General Charles C. Krulak, Commandant of the Marine Corps from 1995 to 1999, drove new doctrine and thinking. In 1997, he envisioned modern war as urban and complex, labeling it a three block war.

In one moment in time, our service members will be feeding and clothing displaced refugees.... In the next moment, they will be holding two warring tribes apart ... and, finally, they will be fighting a highly lethal midintensity battle-all on the same day ... all within three city blocks. ${ }^{51}$

In a three block war, tactics have the potential to take on strategic importance, elevating the significance of young Marines. Two years later, Krulak elaborated on this as the strategic corporal.

The inescapable lesson of . . recent operations, whether humanitarian assistance, peacekeeping, or traditional warfighting, is that their outcome may hinge on decisions made by small unit leaders, and by actions taken at the lowest level.... Success or failure will rest, increasingly, with the rifleman and with his ability to make the right

\footnotetext{
$5^{\circ}$ Operations Other Than War, vol. 1, Humanitarian Assistance (Fort Leavenworth, KS: Center for Army Lessons Learned, 1992), 18. Copies of this difficult-to-find publication are held at the Army Logistics University Library, Fort Lee, VA.

${ }^{51}$ Charles C. Krulak, "The Three Block War: Fighting in Urban Areas," Vital Speeches of the Day 64, no. 5 (15 December 1997): 139-41.
}

decision at the right time at the point of contact. . $^{2}$

The concepts of three block war and the strategic corporal both emphasize the strategic implications of tactical actions, as well as the outsized influence of individual Marines.

In the complex missions envisioned by Krulak, having Marines highly trained in warfighting was insufficient in itself. Krulak described a hypothetical peace operation, Operation Absolute Agility, in a failed African country, in which a routine day overseeing the distribution of humanitarian rations descended into violence. A fictitious Corporal Hernandez, in charge of a security checkpoint, was faced with advancing militants, a downed helicopter with at least two survivors, and an injured Marine in their unit. How they responded, according to Krulak, "would determine the outcome of the mission and have potentially strategic implications." ${ }^{53}$ The decentralized nature of these operations, Krulak contended, would mean Marines would have to operate "without direct supervision from senior leadership" in environments with "a bewildering array of challenges and threats" and under intense scrutiny from the media and politicians. ${ }^{54}$ The strategic corporal needed to be able to balance potentially conflicting mission requirements. In the case of Corporal Hernandez, directly confronting the advancing militants would likely have led to casualties among the civilians waiting to receive food aid, which would "jeopardize the success of the humanitarian mission." 55 A tactical victory over militants could cause strategic failure. Instead, young Marines needed the training-and cultural awareness-to find alternative solutions. Furthermore, Krulak recognized that the success of peace operations rests not only on how local political elites view America and the operation, but on how ordinary civilians perceive the mission:

${ }^{52}$ Charles C. Krulak, "The Strategic Corporal: Leadership in the Three Block War," Marine Corps Gazette 83, no. 1 (January 1999): 20, emphasis original.

${ }^{53}$ Krulak, "The Strategic Corporal," 18-20.

${ }^{54}$ Krulak, "The Strategic Corporal," $20-21$.

${ }^{55}$ Krulak, "The Strategic Corporal," 22. 
"In many cases, the individual Marine will be the most conspicuous symbol of American foreign policy." ${ }^{6} 6$ The behavior of Marines on patrol, at checkpoints, handing out humanitarian rations, and while under fire has the potential to dramatically shape and reshape local understandings of both peace operations and America.

Krulak was part of a broader change in how Marine Corps officers perceived the changing activities and role of the Corps. Having the support of the Commandant ensured that this branch of Marine Corps culture heavily influenced new doctrine and disseminated throughout the Corps. By the time of the 1999 Kosovo War, just a few months after Krulak published his second article, officers of the 26th MEU understood their actions through the conceptual framework of three block war.

\section{The MCDP Series}

The same year that Krulak formally introduced the concept of three block war, the Marine Corps replaced the FMFM series with Marine Corps Doctrinal Publications (MCDPs). The MCDP series is mostly an update to the post-Cold War environment, but the series does make important strides toward developing peace operations doctrine. This shift is visible in the adoption of military operations other than war (MOOTW) in lieu of low intensity conflict.57 The change in terminology opened space for operations without combat or in which combat was a secondary component. Warfighting argues that Marines should expect to conduct operations ranging from maintaining and restoring order "in civil disturbances or disaster relief operations" to conventional war..$^{58}$ Reflecting not just a grudging acceptance of peace operations but a more fundamental cultural shift, Expeditionary Operations, MCDP 3 , argues that peace operations "have historically been Marine Corps missions" and that Marine amphibious capabilities bring a unique affinity for peace operations compared to other branches of

\footnotetext{
${ }^{56}$ Krulak, "The Strategic Corporal," 21.

57 Warfighting, 4, 5 .

$5^{8}$ Warfighting, 4, 5.
}

the U.S. military.59 As a key mission, Marine involvement in peace operations may include "presence, civil support, counterdrug operations, peace building and peacekeeping, counterinsurgency, and noncombatant evacuation operations." ${ }^{60}$ Readers of Expeditionary Operations may be surprised at the emphasis placed on refugees and internally displaced persons in the doctrine's introduction. Expeditionary Operations argues that, in addition to potentially complicating a military mission, "refugee management may itself be the primary objective of an operation." ${ }^{\prime 1}$

The MCDPs, like the earlier FMFMs, drew heavily on Prussian military theorist Carl von Clausewitz's work in how the doctrines articulated the relationship between conflict and policy. ${ }^{62}$ Warfighting states, "The single most important thought to understand about our theory is that war must serve policy." The doctrine goes on to warn, however, that it is equally important to recognize "that many political problems cannot be solved by military means." ${ }^{13}$ Both Strategy, MCDP 1-1, and Campaigning, MCDP 1-2, emphasize that military force must be "employed in conjunction with other instruments of national power." Expeditionary Operations expands on this concept and applies it directly to MOOTW and peace operations, noting that political considerations are even more important in peace operations than in a conventional war. Critically, $E x$ peditionary Operations argues that based on historical experience, Marines should expect to participate in peace operations that "are generally directed at limited objectives and are often of limited duration." ${ }^{65}$ The underlying assumption of this emerging doctrine on peace operations is that the Marine Corps would rapidly deploy to a developing crisis, stabilize the situ-

\footnotetext{
59 Expeditionary Operations, MCDP 3 (Washington, DC: Headquarters Marine Corps, 1998), 110.

${ }^{60}$ Expeditionary Operations, 4, 5, 12.

${ }^{61}$ Expeditionary Operations, 16.

${ }^{62}$ For a full examination of the influence of Clausewitz on Marine Corps doctrine, see Sgt Paul Boothroyd, "Clausewitz: His Influence on Current Marine Corps Doctrine," Marine Corps Gazette 97, no. 7 (July 2013): 81-84. ${ }^{63}$ Warfighting, 23.

${ }^{64}$ Campaigning, MCDP 1-2 (Washington, DC: Headquarters Marine Corps, 1997), 3. A similar statement can also be found in Strategy, MCDP 1-1 (Washington, DC: Headquarters Marine Corps, 1997), 47.

${ }^{65}$ Expeditionary Operations, 110.
} 
ation and fulfill short-term political and military objectives, and then hand over long-term responsibility to either another branch of the U.S. government, to the United Nations and NGOs, or to the host nation itself. This set Marine Corps peace operations doctrine apart from contemporary work on nation-building or the later emergence of stability operations, which became particularly dominant during the wars in Afghanistan and Iraq.

Although the MCDPs were published before or at the same time as Krulak's articles on the three block war and strategic corporal, they draw from the same cultural strand within the Marine Corps. For example, Strategy argues

Every military action has potential strategic implications. . . Marines must understand that the "distance" between local or tactical actions and the effects of these actions at the strategic or political level may be very short. Sometimes a seemingly unimportant action by any participant-a general, a platoon leader, or even one single Marine-can have a powerful political impact. ${ }^{66}$

Strategy may lack the catchphrase strategic corpo$\mathrm{ral}$, but the concept is readily apparent. Again echoing three block war, Strategy calls for cooperation between various "instruments of power," including military, humanitarian, diplomatic, economic, and informational. The informational component incorporated not only information management, but also targeted humanitarian aid ${ }^{67}$ Campaigning expands on this idea: "Depending upon the nature of the operation, the military campaign may be the main effort, or it may be used to support diplomatic or economic efforts." Particularly in peace operations, "the military campaign is so closely integrated with other government operations that these nonmilitary actions can be considered to be part of the campaign." ${ }^{68}$ In addition to echoing

\footnotetext{
66 Strategy, 4.

${ }^{6}$ Strategy, 47-49.

68 Campaigning, 3 .
}

three block war, these statements also reflect the reality of Marine experiences in peace operations in the 1990s, such as Operation Provide Comfort, which required close cooperation with the State Department, the U.S. Agency for International Development (USAID), the United Nations, and numerous NGOs.

While the MCDP series explored peace operations, discussions remained largely conceptual. More detailed considerations focused on combat. This created a contradiction in which peace operations were held up as important missions of the Marine Corps, but no guidance was developed on how to plan or conduct a peace operation.

\section{Peace Operations Training}

At roughly the same time that the Marine Corps began drafting the MCDP series, the Corps also began to rework its training program to include peace operations. Prior to 1995, training for peace operations was largely limited to civilian evacuations. In 1995, a broader range of peace became important to the training for MSSGs. The training routines of the 26 th MEU and MSSG 26 demonstrate this shift. In the first six months of 1995, MSSG 26 conducted three peace operations exercises. Whether because of the perceived significance of these new missions or the MSSG's discomfort, the unit's command chronology spends an unusual amount of space reporting on these training exercises. In the first exercise, MSSG 26 erected "a small camp" where displaced civilians received food, water, and medical treatment. The report noted, "The HA [humanitarian assistance] mission is new to the MEU and was stressed throughout the workup period." ${ }^{\text {"69 }}$ About a month later, MSSG 26 conducted another exercise for the "new and very important mission" of humanitarian assistance. But, it warned, "Humanitarian Assistance missions are potentially very large in magnitude." The practice mission, on the other hand, was modest in scope, including only 20 displaced people, but it was "the MSSG's first major attempt at the HA mission. Valuable after action

\footnotetext{
${ }^{69}$ D. K. Cooper, MEU Service Support Group 26 Semi-Annual ComdC, January 1995-June 1995, secs. 2-3, file 20/1733, Archives Branch, Marine Corps History Division, Quantico, VA.
} 
comments were obtained." $7^{\circ}$ Finally, the next month, MSSG 26 conducted a similar operation that "provided an outstanding opportunity for the MSSG to refine its procedures and internal processes." ${ }^{71}$

While peace operations became a standard part of MSSG training, it was not until 1998 that the whole 26th MEU participated in a peace operation training exercise. In the spring of 1998 , the 26 th MEU took part in Dynamic Response 1998, a NATO-led stabilization force exercise in Bosnia. The exercise was built around the concept of three block war and contained aspects of peacekeeping, humanitarian assistance, and medium-intensity conflict. Dynamic Response aimed to "display NATO commitment to regional stability" through "aggressive presence and professionalism."72 Staff Sergeant Jan Havey reflected, "I think our actions really epitomized Dynamic Response. We were there as a show of force, but also to help. I think the civilian population really saw that point and received it well." The staff sergeant continued, "Every time you go into a peacekeeping situation you have to have two faces. You've got to have a peacekeeping and a war face."73 Havey's statement offers a glimpse into how noncommissioned officers perceived peace operations. Dynamic Response was only one of a wave of exercises that incorporated peace operations in 1998. In 1999, the 26th MEU put all of this training to the test in Kosovo.

\section{Kosovo, 1999}

As the 26th MEU trained for peace operations in Bosnia in 1998, the situation in Kosovo deteriorated dramatically, culminating with a brutal Serbian cam-

\footnotetext{
${ }^{70}$ Cooper, MSSG 26 Semi-Annual ComdC, January 1995-June 1995.

${ }^{71}$ Cooper, MSSG 26 Semi-Annual ComdC, January 1995-June 1995.

$7^{72}$ Col E. N. Gardner, "Strategic Reserve Forces, Briefing," 1998, 2, item 7 , file 1/1732, 26th MEU January 1998-June 1998, Archives Branch, Marine Corps History Division, Quantico, VA; and Gardner, "Post Deployment Brief, 26th Marine Expeditionary Unit, Special Operations Capable," 26 July 1998, item 1, in K. J. Glueck, 26th MEU ComdC, 1 July 1998-31 December 1998, Archives Branch, Marine Corps History Division, Quantico, VA.

73 Cpl Jon Wilke, "Corpsman Assists in Life-Threatening Situation," Globe, 21 May 1998, item 33, file 1/1732, 26th MEU ComdC, January 1998June 1998, Archives Branch, Marine Corps History Division, Quantico, VA.
}

paign of ethnic cleansing against ethnic Albanians and the collapse of diplomatic efforts. On 24 March 1999, NATO launched Operation Allied Force, a 78-day bombing campaign. During the next three months, more than 900,00o ethnic Albanian refugees fled into Albania, Macedonia, and Montenegro. An estimated 530,000 refugees found shelter in Albania, 350 ,ooo in Macedonia, and 70,000 in Montenegro. ${ }^{74}$ In scenes reminiscent of the Kurdish crisis and Operation Provide Comfort in 1991, the UNHCR and NGOs struggled to respond to the speed and scale of the Kosovar refugee crisis. ${ }^{75}$ Particularly in Albania, with its poor infrastructure and rugged terrain, the U.S. military took the lead role in providing international refugee assistance. ${ }^{7}$ On 9 June 1999 , NATO and Serbia agreed to the terms of the Military Technical Agreement, ending Operation Allied Force and paving the way for the deployment of the Kosovo Force, NATO's peacekeeping force. The 26th MEU, which had been assisting Kosovar refugees in southern Albania, entered Kosovo on 13 June and was fully established in the area of Gjilan (Gnjilane in Serbian) by 17

\footnotetext{
${ }^{74}$ The standard number of refugees in Albania for the crisis is 450,000 . However, the Prefecture of Kukës's records indicated that the UNHCR never registered at least 60,ooo Kosovar refugees who stayed with Kukës families. For a representative UNHCR account, see Andrew Jones, Albania: Direct and Indirect Environmental Impacts of Refugees, 17-24 September 2000 (Geneva, Switzerland: UNHCR Engineering and Environmental Services Section, 200o), 4; and Walter Clarke, "The Humanitarian Dimension in Kosovo: Coordination and Competition," in Lessons from Kosovo: The KFOR Experience, ed. Larry Wentz (Washington, DC: Department of Defense Command and Control Research Program, 2002), 214. The relevant Kukës Prefecture records are in three boxes in the Arkiva e Prefekturës së Kuksit: Dosje Nr.1.1999: Prefekti, Dosje nr.1-7. Sek. Pergjithshem nga 1-12, and Dosje nr.17, 1999. Per te ardhurit nga Kosova. 75 The UNHCR was heavily criticized for its role during the Kosovo refugee crisis and its shortcomings are vividly detailed in Astri Suhrke et al., The Kosovo Refugee Crisis: An Independent Evaluation of UNHCR's Emergency Preparedness and Response, pre-pub. ed. (Geneva, Switzerland: UNHCR Evaluation and Policy Analysis Unit, 200o).

${ }^{76}$ Mary Elizabeth Walters, "Constructing Air Power: Air Force Civil Engineers during Operation Allied Force and Operation Shining Hope, 1999" (conference paper, Society for Military History Annual Conference, Columbus, OH, 10 May 2019); and Mary Elizabeth Walters, "Unexpected Humanitarians: Albania, the U.S. Military, and Aid Organizations During the 1999 Kosovo Refugee Crisis" (conference paper, Triangle Institute for Security Studies New Faces Conference, Chapel Hill, NC, October 2018).
} 
June. ${ }^{77}$ Operations in Kosovo tested both the MCDP series and Marine training in peace operations. While the operation was largely successful, the 26th MEU identified serious gaps in both areas.

The 26th MEU's mission was to monitor and enforce "compliance with [the] ceasefire," provide humanitarian assistance, establish "Initial Basic Law and Order Enforcement and Core Civil Functions," and facilitate "Peace and Stability within the Region..$^{7}$ The commander's intent was to "Conduct Peace Enforcement Operations," but be prepared to "transition to combat operations at a moment's notice" in line with three block war.79 Major Nathan S. Lowrey argued that Krulak's concept of the three block war "influenced the 26th MEU's concept of operations in Kosovo and contributed to the formation of parallel civil and military missions during the pursuit of peace." ${ }^{\text {8o }}$ At all levels of the 26th MEU's mission in Kosovo, peace operations occupied a central role. ${ }^{81}$

As Krulak had argued, in Kosovo the ability of the MEU to build strong relationships with local Albanian and Serbian communities, on which so much of their mission depended, rested in the hands of the strategic corporal. The commander of Battalion Landing Team, 3d Battalion, 8th Marines (BLT 3/8), Lieutenant Colonel Bruce A. Gandy, reflected that in Kosovo "within each sector the company commander acted as the military commander, police chief, and

\footnotetext{
77 "Current Status of the 26th MEU (SOC)," 26th MEU, June 1999, file 6/1 Yugoslavia Peacekeeping 26th MEU Press Releases 1999, box 23/D/3/7$\mathrm{A} / 25 / \mathrm{A} / 5 / 5$, Operations Other Than War Yugoslavia Peacekeeping, 1999-2000, Box 1, Archives Branch, Marine Corps History Division, Quantico, VA; and B. A. Gandy, BLT 3/8 ComdC, 1 January 1999-31 July 1999, Archives Branch, Marine Corps History Division, Quantico, VA. ${ }^{78}$ Briefing Slides, CTF 61/62 COAs for Initial Entry Force Operations in Kosovo, item 6, in K. J. Glueck, 26th MEU ComdC, 1 January 199931 July 1999, Part 1, Archives Branch, Marine Corps History Division, Quantico, VA.

79 Briefing Slides, 26th MEU (SOC) Initial Entry Force Operations in Kosovo, item 7, in Glueck, 26th MEU ComdC, 1 January 1999-31 July 1999, Part 1.

${ }^{80}$ Maj Nathan S. Lowrey, "Operation Joint Guardian: The 26th MEU During Peacekeeping Operations in Kosovo, 1999," PowerPoint Presentation, 1999, file 2/1733 26th MEU C/C, box 1733 C/3/A/65 90-99, Archives Branch, Marine Corps History Division, Quantico, VA.

${ }^{81}$ Briefing Slides, 26th MEU (SOC) Initial Entry Force Operations in Kosovo.
}

civil administrator." ${ }^{22}$ Developing strong relationships with the local community relied on small unit patrols. This put the burden of trust-building on every Marine. Captain David W. Eiland used daily patrols "to foster a working relationship with the villagers and to get a feeling of the 'temperature' of the village. . . In short, we were the villagers' security blanket." ${ }_{3}$

Despite the 26th MEU's peace operations training, many officers found themselves and their soldiers unprepared for the scale of their responsibilities in Kosovo. Gandy warned,

Currently, the intensive MEU workup training schedule does not provide any training or instruction in the area of civil affairs. In Operation Restore Hope in Somalia, Operation Uphold Democracy in Haiti [1994-95], and now Operation Joint Guardian in Kosovo, Marine Corps forces have been called upon to assume these duties and assist in the restoration of core civil functions. Although it is accurate to say that fundamental tactics training provides skills necessary in this realm, it does not prepare unit commanders for the full spectrum of challenges in this arena. $^{84}$

As a result, the 26th MEU relied heavily on the six members sent from the 4 th Civil Affairs Group, a Marine Reserve unit, rather than internal MEU assets. The 4th Civil Affairs Group took the lead in a wide range of activities, including coordination between the MEU, NGOs, and community leaders, providing NGO security, and negotiating power sharing ar-

\footnotetext{
${ }^{82}$ LtCol Bruce A. Gandy, "The Kosovo Commitment: Force Protection and Mission Accomplishment," Marine Corps Gazette 83, no. 11 (November 1999): 45 .

${ }^{8}$ Capt David W. Eiland, "The Kosovo Commitment: Company K," Marine Corps Gazette 83, no.11 (November 1999): 51.

${ }^{8}$ Commanding Officer, Battalion Landing Team 3/8, "Quick Look After Action Report Operation Joint Guardian," 26 July 1999, item 27, in K. J. Glueck, 26th MEU ComdC, 1 January 1999-31 July 1999, Part 2, Archives Branch, Marine Corps History Division, Quantico, VA.
} 
rangements between Serbs and Albanians. ${ }^{85}$ The $4^{\text {th }}$ Civil Affairs Group also organized the movement of both ethnic Serbian and Albanian refugees and assisted MSSG 26 with humanitarian assistance. ${ }^{86}$

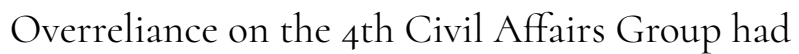
the unintentional side effect of decreasing the buy-in of the rest of the 26th MEU to many peace operations requirements. Because the 4 th Civil Affairs Group was only temporarily attached to the 26th MEU and not part of the standard chain of command, unit commanders only followed their advice when convenient and when the tactical advantage was readily apparent. For example, unit commanders were reluctant to provide security escorts for refugee convoys because it diverted resources from security patrols. The 4 th Civil Affairs Group complained that this increased the "potential for violent confrontations between ... opposing ethnic group[s and could] have negatively impacted the MEU's ability to fulfill its primary mission of providing security." ${ }^{87}$ Many of the MEU's after action reports complained about the amount of resources devoted to humanitarian and development work. For example, the logistics section concluded, "Providing care to the Marines and Sailors of the MEU is the PRIMARY CONCERN of the medical department. We must never lose sight of this when providing humanitarian assistance to others." ${ }^{\text {88 }}$

Despite internal resistance, the 26th MEU worked hard to provide humanitarian assistance and to restore basic infrastructure. As with Operation Provide Comfort in 1991, the MSSG played a key

\footnotetext{
${ }^{85}$ Glueck, 26th MEU ComdC, 1 January 1999-31 July 1999, Part 1, sec. 2; Civil Affairs Officer, "Measures of Effectiveness," 24 July 1999, item 32, in Glueck, 26th MEU ComdC, 1 January 1999-31 July 1999, Part 3, secs. 3-32-1; and Commanding Officer, "MSSG-26 Measures of Effectiveness: Operation Joint Guardian," 12 July 1999, Item 38, in Glueck, 26th MEU ComdC, 1 January 1999-31 July 1999, Part 3.

${ }^{86}$ Commanding Officer, "MSSG-26 Measures of Effectiveness: Operation Joint Guardian," secs. 3-38-5; and Glueck, 26th MEU ComdC, 1 January 1999-31 July 1999, Part 1, sec. 2.

${ }^{87}$ J. Burack, "Quick Look After Action Report Operation Joint Guardian," item 19, Civil Affairs After Action Report for Operation Joint Guardian, in Glueck, 26th MEU ComdC, 1 January 1999-31 July 1999, Part 2, secs. 3-4.

${ }^{88}$ Logistics Officer, "Operation Joint Guardian Quicklook," 19 July 1999, item 24, in Glueck, 26th MEU ComdC, 1 January 1999-31 July 1999, Part 2, secs. 3-9, emphasis original.
}

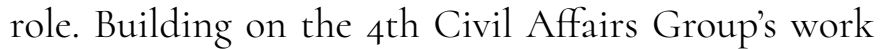
to negotiate power-sharing arrangements, the MSSG reinforced these agreements by providing supplies and engineers to get facilities operational again. On a more temporary basis, the MSSG established regular medical and dental pop-up facilities in villages throughout the 26th MEU's area of responsibility. In addition to the humanitarian aspect of these efforts, the 26th MEU's after action report reflected that they used their resources to "establish a relationship with hostile or indifferent communities in order to gain influence, credibility and cooperation for the line companies patrolling those villages." ${ }^{19}$ The MSSG 26 argued that these projects provided "another forum for communities to address numerous issues from human rights violations to weapons turn-in." ${ }^{\circ \circ}$ BLT $3 / 8$ also contributed to efforts to restore infrastructure. Patrols "met with local leaders to determine status of infrastructure," focusing on the fire department, emergency services, and basic utilities. Even though BLT $3 / 8$ patrols could rarely solve problems themselves, they "did establish the groundwork and identify requirements to follow-on forces/agencies such as the US Army, United Nations etc." ${ }^{91}$ Captain John R. Anderson observed, "Even if we could do very little, these small, seemingly insignificant acts helped gain their trust." ${ }^{2}$

While humanitarian and development work faced the most internal pushback, the area in which the 26th MEU particularly struggled was policing. The main conduit for locals to report crime was through a 911 system established at the Gjilan police station. However, the Criminal Investigation Division's after action report condemned the responses of the 26th MEU to these calls, reporting, "Local BLT units in the area declined to respond to a majority of calls for ser-

\footnotetext{
89 Burack, "Quick Look After Action Report Operation Joint Guardian," secs. 3-5.

$9^{\circ}$ Commanding Officer, "MSSG-26 Measures of Effectiveness," secs. 3-38-3.

${ }_{91}^{1}$ Operations Officer, BLT 3/8, "BLT 3/8 Measure of Effectiveness Analysis," 11 July 1999, Item 36, in Glueck, 26th MEU ComdC, 1 January 1999-31 July 1999, Part 3, secs. 3-36-2.

$9^{2}$ Capt John R. Anderson, "The Kosovo Commitment: Forward Operating Base," Marine Corps Gazette 83, no. 11 (November 1999): 50.
} 
vice since they were there 'to conduct tactical security patrols' and could not be bothered with responding to citizen complaints."93 When BLT $3 / 8$ did respond, the report continued, "In some instances, individuals that were processed as detainees were actually witnesses to a crime, but were handled and processed with the criminal elements." ${ }^{4}$ During training, "the MEU had never, throughout all the work-ups, actually gone through a process of detaining real people ... and have no idea how to document circumstances surrounding detention properly." 95 Marines defaulted to treating detainees as prisoners of war, rather than potential lawbreakers. ${ }^{96} \mathrm{BLT} 3 / 8$ was fully aware of its shortcomings, noting, "Actually apprehending people was not a problem, but the processing and transportation of detainees seemed, at times, to be more trouble than it was worth." ${ }^{97}$ The issue of detainees combined insufficient numbers of military police, a lack of MEU training, and legal confusion-the result was a concerning prelude to mistreatment of detainees during the Iraq War a few years later.

Despite these problems, the 26th MEU's staff judge advocate argued that the MEU "got police functions working under the rule of law, despite the fact that when we went in, there was no law to work under, or anything planned as to how to deal with police functions." ${ }^{8}$ In practice, there was significant blurring between some aspects of police functions and security patrols. The mere fact of regular security patrols and Marines willing to practice "aggressive restraint" decreased violence. A week into their time in Kosovo,

${ }^{3}$ CWO 2 Gary J. Schmidt, 26th MEU CE/Criminal Investigation Division, "Quick Look After Action Report Operation Joint Guardian," 17 July 1999, item 18, in Glueck, 26th MEU ComdC, 1 January 1999-31 July 1999, Part 2, sec. 3-2,3.

${ }^{94}$ Schmidt, "Quick Look After Action Report Operation Joint Guardian."

${ }_{95}$ Capt E. F. Crail, Staff Judge Advocate, "Quick Look After Action Report Operation Joint Guardian," 18 July 1999, item 12, in Glueck, 26th MEU ComdC, 1 January 1999-31 July 1999, Part 2, sec. 3.

${ }^{6}$ Schmidt, "Quick Look After Action Report Operation Joint Guardian."

${ }_{97}$ Commanding Officer, "Quick Look After Action Report Operation Joint Guardian," secs. 3-7.

${ }^{98}$ Captain E. F. Crail, Staff Judge Advocate, "Measures of Effectiveness," 25 July 1999, item 30, in Glueck, 26th MEU ComdC, 1 January 1999-31 July 1999, Part 3, secs. 3-30-1.
Marines from BLT $3 / 8$ captured a Serbian sniper in Gjilan who had killed two Albanian civilians. In a case the following week, Marines protected a statue of Serbian Prince Lazar Hrebeljanović from ethnic Albanians' rioting.99 The BLT 3/8 reported, "By default, the Marines became the security and police force in the sector" and crime in the area "declined immediately. Markets returned, shops and businesses reopened, public transportation began to run reliably again, and the lives of the citizens seemed to return closer to normal." ${ }^{\text {10o }}$

The 26th MEU's month and a half in NATO's Kosovo Force was far from perfect. Yet even today, ethnic Albanians in Kosovo speak very favorably of American soldiers, Marines, and NATO, though they often struggle to differentiate among them. Both at the time and in oral histories, many commented that the Americans and NATO made them feel safe to return to their homes. Agim Byçi captured some of the emotion of the time, saying in an interview that after NATO forces reached Gjakova, "then began joy, merriment and bliss, life, freedom, and gratitude for the European Union and especially for America." ${ }^{101}$ Islam Shahiqi, a Kosovar coffee shop owner in the 26th MEU's area of operations, reflected, "It's the first time in years that I feel free. ... I was afraid during the bombing, but I was more afraid of the Serbs. Now I feel protected by NATO." ${ }^{102}$ The 26th MEU took the training they had, expanded on it where they could, and created new policies as needed.

\section{Conclusion}

In September 2001, the Marine Corps published $\mathrm{Ma}$ rine Corps Operations, MCDP 1-O, which included the first Marine peace operations doctrine in its 1oth

\footnotetext{
${ }^{99}$ Lowrey, "Operation Joint Guardian."

${ }^{100}$ Maroco R. della Cava, "Marines Get a Taste of Wild West in Chaotic Kosovo," USA Today, 21 June 1999, item 67, in Glueck, 26th MEU ComdC, 1 January 1999-31 July 1999, Part 3, secs. 3-67-1; and Operations Officer, Battalion Landing Team 3/8, "BLT $3 / 8$ Measure of Effectiveness Analysis," 11 July 1999, item 36, in Glueck, 26th MEU ComdC, 1 January 1999-31 July 1999, Part 3, secs. 3-36-2.

${ }^{101}$ Agim Byçi and Neserete Nuka, interview with Mary Elizabeth Walters, Gjakova, Kosovo, 28 May 2016.

${ }^{102}$ della Cava, "Marines Get a Taste of Wild West in Chaotic Kosovo," secs. $3-67-1$.
} 
chapter on MOOTW. ${ }^{103}$ The chapter highlights the "political and cultural considerations" of peace operations. ${ }^{104}$ Marine Corps Operations argues peace operations were key to the Marine Corps' mission.

Naval expeditions ... have long been the instruments of choice in our $\mathrm{Na}$ tion's response to global contingencies. From humanitarian assistance, to peacekeeping, to combat, these forces are normally the first on scene and ready to respond. . . They provide a power projection capability that can be tailored to meet a wide range of crises from a major theater war to military operations other than war (MOOTW). ${ }^{105}$

Although Marine Corps Operations largely follows joint doctrine on peace operations, the Marine Corps version of peace operations is a naval expedition that responds to a rapidly developing crisis. The type of operation envisioned is very much in line with experiences in Operation Provide Comfort and Kosovo Force: a Marine unit already at sea would be diverted to respond to a crisis using its amphibious capabilities. While the operation might take place inland, as both the northern Iraq and Kosovo operations did, the versatility of Marine structures and logistics would allow Marines to respond with both overwhelming force and humanitarian aid. Once Marines established security and basic assistance, Marine Corps Operations envisions Marines handing over responsibility to other U.S. military forces, to the United Nations, or to NGOs.

The publication is a strong starting point for doctrinal development for peace operations. Echoing Krulak's vision of three block war, Marine Corps Operations argues, "Marines may be conducting combat, peace enforcement, and humanitarian assistance op-

\footnotetext{
${ }^{103}$ LtCol John A. Bass, (Ret), "Marine Corps Doctrinal Publication 1-o, Marine Corps Operations," Marine Corps Gazette 87, no. 10 (October 2003): 22-25.

${ }^{104}$ Marine Corps Operations, MCDP 1-o (Washington, DC: Headquarters, U.S. Marine Corps, 2001), 10-3, hereafter Marine Corps Operations (2001). ${ }^{105}$ Marine Corps Operations (2001), 1-3.
}

erations simultaneously within an emerging nation in an austere theater or a major metropolitan city." ${ }^{106}$ As a result, the strategic corporal remains key as "small unit leaders may conduct tactical actions that have operational and even strategic consequences." ${ }^{107}$ The doctrine also provided brief overviews of common subsets of peace operations, including specific tasks Marines would be expected to perform and historical examples of similar deployments. For example, the section on humanitarian assistance explains under what conditions the United States provides aid, which governmental bodies may declare a disaster, and the types of aid missions on which Marines could be deployed, and it referenced Operation Provide Comfort as one of the examples. ${ }^{108}$ Though the level of detail failed to match the careful diagrams of Marine Air-Ground Task Force (MAGTF) tactics and maneuvers, the doctrine was still a significant improvement from the more conceptual coverage of earlier MCDPs. ${ }^{109}$

Departing slightly from the previous MCDPs, Marine Corps Operations urges patience because operations "may require years to achieve the desired results. ... The patient, resolute, and persistent pursuit of national goals and objectives, for as long as necessary to achieve them, is often a requirement for success." Throughout this period, Marines must "sustain the legitimacy of the operation" in the eyes of the American public, local populations, and the international community. ${ }^{110}$ Despite recognizing the potential longterm nature of peace operations and the strain that longevity might place on the mission's legitimacy, Marine Corps Operations does not address what should happen when American political leaders lack the patience or interest to stay the course. This was a serious weakness, as was demonstrated by the United States' reluctant participation in 2004's multinational peace

\footnotetext{
${ }^{106}$ Marine Corps Operations (2001), 1-6.

${ }^{107}$ Marine Corps Operations (2001), 1-9.

${ }^{108}$ Marine Corps Operations (2001), 10-8, 10-9.

${ }^{109}$ A comparison of chapter 10, "Military Operations Other Than War," with chapter 7, "The MAGTF in the Offense," and chapter 8, "The MAGTF in the Defense," in Marine Corps Operations makes this contrast in the level of detail immediately apparent.

${ }^{110}$ Marine Corps Operations (2001), 10-6.
} 
operations in Haiti following the removal of Haitian President Jean-Bertrand Aristide. ${ }^{111}$

The Corps published Marine Corps Operations just days after al-Qaeda's 11 September 2001 terrorist attacks. Almost overnight, the strategic environment changed and the predominant mission of the Marine Corps shifted to a ground infantry role during the wars in Afghanistan and Iraq. Marine Corps interest in peace operations evaporated. Attention shifted to counterinsurgency, nation-building, and later stability operations. Some of the concepts and practices of peace operations carried over, but in very different contexts. Worse, many of the hard-learned lessons of the 1990 os were forgotten. In March 2003, U.S. Marines took control of an-Nasiriyah, Iraq. A Marine Corps colonel found himself the mayor of eight cities. He recalled, "I had no idea I would be responsible for getting the water running, turning on the electricity, and running an economy," all tasks that he should have expected based on the experiences of the 24th MEU in northern Iraq and the 26th MEU in Kosovo. ${ }^{112}$

Even though the Corps paid greater attention to peace operations in the 1990s, Marine Corps doctrine did not develop beyond the level of detail provided in 2001's Marine Corps Operations. This is most evident in the 2011 revision of Marine Corps Operations. As Commandant General James F. Amos observed in the new foreword, since 2001 Marines had deployed on a great "diversity of operations," ranging from deployments $644 \mathrm{~km}$ inland in Afghanistan to foreign humanitarian assistance missions. ${ }^{113}$ As a result of the changes wrought by a decade of fighting in Afghanistan and Iraq, the Corps made significant revisions to Marine Corps Operations. Rather than a single chapter on MOOTW, different aspects of peace operations were spread across three chapters. The first aspect of peace operations fell under the category of military engagement. One potential aspect of military engagement,

\footnotetext{
${ }^{111}$ Alan McPherson, A Short History of U.S. Interventions in Latin America and the Caribbean (Chichester, UK: Wiley Blackwell, 2016), 185-87.

${ }^{112}$ Janine Davidson, "Giving Peacekeeping a Chance: The Modern Military's Struggle over Peace Operations," Small Wars and Insurgencies 15, no. 2 (2004): 168, https://doi.org/10.1080/0959231042000282670.

${ }^{113}$ Marine Corps Operations, MCDP 1-o (Washington, DC: Headquarters, U.S. Marine Corps, 2011), i, hereafter Marine Corps Operations (2011).
}

according to the updated Marine Corps Operations, is nation assistance, the civil and military "assistance rendered to a nation by foreign forces within that nation's territory during peacetime, crises or emergencies, or war." Nation assistance includes humanitarian and civic assistance, security assistance, and support to foreign and internal defense. These possibilities, however, receive only cursory attention-less than one full page. ${ }^{114}$

Peace operations received far greater coverage in the following chapter on crisis response and limited contingency operations. The revised Marine Corps Operations opens with a nuanced discussion of the historic precedent provided by the Corps' experience in small wars and how twenty-first century crisis response and limited contingency operations fit into U.S. national strategy. A closer examination of the specific types of operations with which Marines could be tasked reveals that the descriptions remain almost identical to those from the original 2001 publication. For example, in 2001, Marine Corps Operations defined peacekeeping as operations "conducted with the consent of all major belligerents." ${ }^{15}$ In 2011, the wording shifted slightly, defining peacekeeping as "military operations undertaken with the consent of all major parties to a dispute." ${ }^{116}$ Other than adjusting minor phrasing, the revised Marine Corps Operations did not provide further doctrinal development of peace operations.

Finally, the 2011 Marine Corps Operations includes a brief chapter on stability operations, a category of missions as difficult to define as peace operations and with a great deal of overlap. Indeed, Marine Corps Operations resorts to defining stability operations by listing the tasks and activities conducted by U.S. military forces on such missions. ${ }^{117}$ In six pages, Marine Corps Operations provides a succinct overview of stability operations and directs readers to other doctrinal publications by the Department of Defense and the Department of State for further detail. Marine Corps

\footnotetext{
${ }^{114}$ Marine Corps Operations (2011), 4-4, 4-5

${ }^{115}$ Marine Corps Operations (2001), 10-12.

${ }^{116}$ Marine Corps Operations (2011), 5-8.

${ }^{117}$ Marine Corps Operations (2011), 12-1.
} 
Operations itself, however, remains vague on the role of Marines during stability operations.

Today, the future approach of the Marine Corps to peace operations is once again in question. The 38th Commandant, General David H. Berger, has stated, "We cannot assume that today's equipment, the way that we're organized, how we train, how we select leaders, all of our warfighting concepts, we cannot assume they will remain relevant in the future. My assumption is they will not." ${ }^{{ }_{118}}$ General Berger's 2019 Commandant's Planning Guidance calls for a rethinking of everything, from force structure to equipment. The only certainties seem to be that the Marines will remain the "naval expeditionary force-in-readiness" for the United States and that the Corps will seek deeper integration with the U.S. Navy. ${ }^{119}$ Colonel Paul Weaver, the head of Combat Development Command, recently remarked, "We are going to bring about a level of change in the Marine Corps that we have probably not seen at least in [our] lifetime." ${ }^{120}$ Most relevant for the Marine Corps' involvement in peace operations-and in a dramatic break from the 2016 Marine Corps Operating Concept-Berger declared, "We are not an across-the-ROMO [range of military operations] force." Far from including peace operations as key to the Marine Corps' mission, Berger argues that "foreign humanitarian assistance, disaster relief, and noncombatant evacuations do not define us-they are not our identity. Rather, they are the day-to-day consequence of being the force-in-readiness. ${ }^{1212}$ Furthermore, the lighter footprint that Berger calls for could well result in a diminished capability to perform logistics-heavy peace operations of the kind the 24th and 26th MEUs carried out in northern Iraq and Kosovo, respectively. Although the lasting legacy of Marine Corps peace op-

\footnotetext{
${ }^{118}$ Paul McLeary, "Commandant: Marines 'Not Optimized for Great Power Competition'," Breaking Defense, 3 October 2019.

${ }^{119}$ Gen David H. Berger, 38 th Commandant's Planning Guidance (Washington, DC: Headquarters Marine Corps, 2019), 1.

${ }^{120}$ Todd South, "The Commandant Has a New Plan for the Marine Corps. Here's How Marines Will Get the Gear to Make It a Reality," Marine Corps Times, 18 September 2019.

${ }^{121}$ Berger, 38 th Commandant's Planning Guidance, 9.
}

\section{MCAF MEMBERS 100 YEARS OF MARINE CORPS HISTORY ARE YOURS TO EXPLORE}

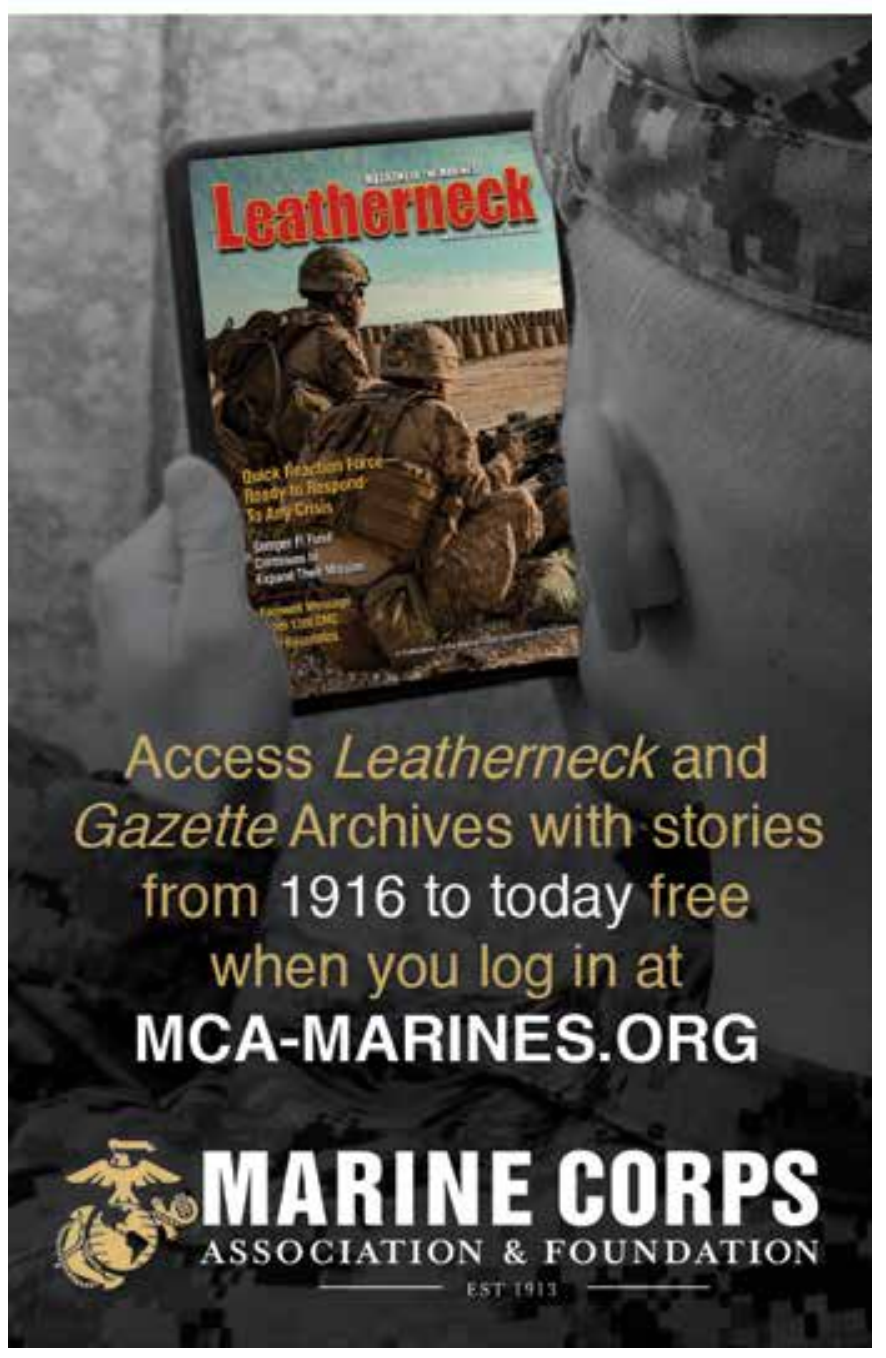

erations practice and doctrine in the 1990 os remains unclear, the 199 os nevertheless saw a dramatic change in Marine Corps culture and perceptions of peace operations. 


\title{
The Triptych \\ of Modern Combat \\ JOE SACCO'S REPORTING ON IRAQ
}

by Cord A. Scott, PhD

\begin{abstract}
While one may read about and imagine combat based on verbal descriptions, visual depictions of warfare convey the information at a more visceral level. Chroniclers of conflict throughout time have tried to accurately depict the sights and concepts of warfare, and a wide variety of visual media have been used to discuss war, including films, television, and comic books. There is a symbiosis between comics and the military. Joe Sacco, who has gained a reputation in the new subfield of comics journalism as a reporter of conflicts around the world, has a knack for explaining the historical developments as well as the more immediate personal connections that bring a story to life. Unlike comic books that simply use war as a theme, Sacco tried to be true to what he observed in the field by drawing images as close to reality as possible. Sacco's three major works on the Iraq War tell different stories in a relatively brief timeframe (2005 to 2007). This article takes Sacco's three Iraq War graphic tales and dissects them to discover whether they convey a written or unwritten commentary on the war and whether they are effective in their intent.

Keywords: war, graphic novels, comic books, war comics, journalism, pictorial journalism, war correspondence, comics journalism, embedded journalist, Operation Iraqi Freedom, OIF, Operation Enduring Freedom, OEF, Gulf War, Iraq War
\end{abstract}

W ar, at its core, is a visual event. While one may read and imagine combat based on verbal descriptions, visual depictions of warfare convey the information at another level. To that end, chroniclers of conflict have tried to accu-

Cord A. Scott holds a doctorate in American history from Loyola University Chicago and currently serves as a professor of history at the University of Maryland, Global Campus for Asia. He is the author of Comics and Conflict: Patriotism and Propaganda from World War II through Operation Iraqi Freedom (2014), as well as Four Colour Combat: Canadian Forces in War Comics (2019). He has written for several encyclopedias; academic journals such as the International Journal of Comic Art, the Journal of Popular Culture, and the Journal of the Illinois State Historical Society; and has contributed to several books on aspects of cultural history. His most recent work is on Marine Corps cartoons in the World War I edition of The Stars and Stripes. He resides in Osan, South Korea.

https://doi.org/10.35318/mch.2019050205 rately depict the sights and concepts of warfare to an audience, whether soldiers or-perhaps more importantly-people for whom the front is remote and abstract: politicians and regular citizens at home. These people are the support basis for any conflict abroad, and if they cannot understand or embrace the reasons driving a war or military action or muster a sense of support or sympathy for the servicemembers involved, then their moral support may lag and fail, as was the case in the United States during the Vietnam War or the first Persian Gulf War and in the Soviet Union during its war in Afghanistan. ${ }^{1}$ More recently, a wider variety of visual media have been used to discuss war,

\footnotetext{
${ }^{1}$ George C. Herring, From Colony to Superpower: U.S. Foreign Relations since 1776 (New York: Oxford University Press, 2008), 909-10.
} 
including films, television, and comic books. This last medium for depictions of warfare has seen contributions by many artists, all of whom have their own take on warfare and its depictions. Comic book readers tend to be in their early zos to 3os, with disposable income, so they fit into the age range of the combatants. ${ }^{2}$ At the same time, comic book superheroes have permeated popular culture through movie franchises and television series, and the success of comic-themed movies has conversely given more exposure to the medium of comic books, though they fit a different niche from the traditional superhero genre. There is a symbiosis between comics and the military. Famous character logos, such as the Punisher's skull, are used by military units, while military themes and storylines have been used in comic books since World War II. ${ }^{3}$

Comic book creators are also looking for different storylines and ways to convey ideas and discuss issues as well as reach more readers, and they have successfully entered the nonfiction category. One of the more recognized creators in the new subfield of comics journalism is Joe Sacco, who has gained a reputation as a reporter of conflicts around the world with a knack for explaining the historical developments as well as the more immediate personal connections that bring any story to life.

Sacco has reported on a wide variety of military conflicts in recent years. His style of journalism is a variation of photojournalism. He researches the material and conducts interviews, then sketches the events for either a comic book or longer graphic novel. ${ }^{4}$ His work has concentrated on conflict around the world and has often been published in a more limited form in major news outlets, such as the New York Times, Time magazine, the Guardian, or Harper's magazine. In addition to being translated into 14 languages, Sacco's work has earned him several honors, including an American Book Award, a Ridenhour Book Prize,

\footnotetext{
${ }^{2}$ Vaneta Rogers, "Is the Average Age of Comic Book Readers Increasing?: Retailers Talk State of the Business 2017," Newsarama, 2 February 2017. ${ }^{3}$ For further analysis, see Cord A. Scott, Comics and Conflict: Patriotism and Propaganda from World War II through Operation Iraqi Freedom (Annapolis, MD: Naval Institute Press, 2014), specifically chapter 2 on World War II comic books and chapter 6 on Operation Iraqi Freedom comics.

${ }^{4}$ Joe Sacco, Journalism (New York: Metropolitan Books, 2012), xvii.
}

a Will Eisner Comic Industry Award, and a Guggenheim fellowship. While Sacco discusses the intricacies of combat, his work is geared toward a civilian population, not necessarily a military one, which would be focused more on specific language and ideas. The particular episodes from Sacco's work described in this article were based entirely on a civilian's perspective while embedded with Marine units and were written from a viewpoint that those on the ground might consider overly simplistic or even ignorant of military doctrine. 5

Sacco's form of reporting has its origins in the combat illustrators of the American Civil War, who sketched images to give a sense of visual reference in a time when such technologies as high-speed film were not available. Artists for Harper's Weekly and Frank Leslie's Illustrated Newspaper often followed troops and quickly sketched images of events to provide an "action account" of the battles. ${ }^{6}$ This kind of work still has resonance today, but it has effectively flipped from that older era and form. Sacco has made a critically acclaimed career of covering conflict, in particular the Yugoslav War and the fighting in Palestine, primarily on the intifada of the late 1990s. He has used his journalistic education and skills, combined with his artwork, to show combat around the world. His illustrations are similar to other war cartoonists in that he strives for a realistic approach to the look of war and its associated emotions, literal and mental. Unlike comic books that used war as a theme, Sacco tried to be true to the images, weapons, and even dialog that combatants have in the field by drawing the images as close to reality as possible, unlike some comic book artists who draw more exaggerated forms. ${ }^{7}$ At the same time, he tells of the horrors of war and leaves the reader with uncertain outcomes. Such objectivity has been a goal for many reporters covering conflicts.

Sacco's three major works on the Iraq War-covering Operations Iraqi Freedom (OIF) and Enduring Freedom (OEF)-tell different stories in a relatively

\footnotetext{
${ }^{5}$ Sacco, Journalism, 73-106.

${ }^{6}$ Harry L. Katz and Vincent Virga, Civil War Sketch Book: Drawings from the Battlefront (New York: Norton, 2012), 1-3.

7 Scott, Comics and Conflict.
} 
brief timeframe of insurgency in Iraq from 2005 to 2007. Two of the stories deal with the U.S. Marines and their service near Haditha in Western Iraq. They were reported and presented for a civilian population that may not understand the situation in the battle zone. While not as well-known as Sacco's earlier works on conflict, Safe Zone Gorazde or Palestine, the Iraq stories still discuss important aspects of the war, including questioning America's true role-savior or bully-especially during the Iraq invasion. Many governments and citizens of countries around the world opposed the invasion of Iraq, and even when the war was announced to be over and victory declared, the killing of Coalition servicemembers as well as many Iraqis continued unabated. While it may have been entirely happenstance, the publications that ran Sacco's work on Iraq may have been perceived as having antiwar sympathies (e.g., the Guardian in England) or as trying to convince readers of the questionable nature of the evidence and justification for the war in Iraq. ${ }^{8}$ This was never overt in form but was another consideration in his work. Critical analysis of important national issues sometimes is seen as unpatriotic rather than as a necessary reflection on the lessons learned from an event.

Sacco is not the only writer/illustrator to address the Iraq War in a graphic novel format. Embedded journalist David Axe wrote two graphic novels-War Fix (with illustrator Steven Olexa, 2006) and War is Boring: Bored Stiff, Scared to Death in the World's Worst War Zones (with illustrator Matt Bors, 2010)-both of which deal with aspects of reporting and adrenaline. Another embedded journalist, Karl Zinsmeister, wrote Combat Zone: True Tales of GIs in Iraq (with illustrator Dan Jurgens, 2005), a fictionalized war comic. Comics writer Sid Jacobson and illustrator Ernie Colón followed up their graphic novel version of the 9/11 Commission's report, The 9/11 Report: A Graphic Adaptation (2006), with the graphic novel After $9 / 11$ : America's War on Terror (2001-) (2008), which seeks to put into context the post-11 September 2001 (9/11) world. But Sacco's work, rather than the broad over-

\footnotetext{
8 "Iraq: The Case for Decisive Action," Guardian, 18 January 2003.
}

view of a historical monograph, offers a ground-level perspective that allows the reader to contemplate the issues of the war in terms of its human elements. Additionally, Sacco's work is much briefer than a typical comic book or graphic novel (8 pages versus more than 64)-a short-form comics journalism that is more akin to dispatches. ${ }^{9}$ It might be said that he is trying to conduct war reporting in a manner reminiscent of reporters such as Ernie Pyle, from the perspective that by learning about the common combatants and their emotions and thoughts, one might better empathize with them and therefore support the cause. Pyle often traveled with Allied troops during World War II and usually covered the stories of soldiers on the ground rather than the generals who made strategic decisions. He also described life for the servicemembers at the front as well as the conditions in which they fought. Pyle was embedded with military units at a time when the word embedded was not yet used. While in these situations, journalists try to retain a distance so that the information they relate is neutral and use terms that may be common to those in the field but are not necessarily familiar to readers.

This article takes Sacco's three Iraq War graphic tales and dissects them, asking: Do the stories convey a written or unwritten commentary on the war? Does the United States have an effective way of transitioning from U.S. to Iraqi control? Are the stories effective in their intent? The stories and discussion on them are presented in the order in which they were published: "Complacency Kills," first published by the Guardian in 2005; "Trauma on Loan," published by the Guardian in 2006; and finally, "Down! Up!" which was originally published by Harper's magazine in 2007. These stories were later combined into a part of Sacco's collective work Journalism, published in 2012, and for purposes of simplicity, most notes will rely on the pages of the book Journalism.

\section{The Iraq of 2004 and Sacco}

Sacco entered Iraq during its occupation in late fall 2004, when he began compiling information for the

9 Sacco, Journalism, xvii. 
first of the published comics, "Complacency Kills." is important to look at the situation unfolding at the time, especially in al-Anbar Province in the western part of the country, and how the events of the following two years influenced his storylines. For additional reference to the situation on the ground, other sources are available. ${ }^{11}$

Following the cessation of formal combat operations in May 2003, vast parts of Iraq were thrown into rounds of sectarian violence as Shi'ites sought retribution against the Sunnis who ruled the Baath party and therefore all of Iraq. Further complicating matters were various clans as well as terrorist groups who saw the end of Saddam Hussein's regime as a way to reintroduce a caliphate into Iraq, one based on strict interpretation of Sharia law. Finally, other groups decimated by the 2001 U.S. strikes against al-Qaeda in Afghanistan saw the opportunity to branch out to the groups opposed to Western influence in the region. ${ }^{12}$ One of the most important parts of the overall picture in 2004 was the series of events surrounding the city of Fallujah, which had become a symbol of anarchy as well as anti-U.S. insurgency. In April 2004, four security operatives working for the private military contractor Blackwater USA were killed and their bodies desecrated by locals. This act spurred a response by the U.S. Marines in a limited capacity in April 2004 in Operation Vigilant Resolve, followed by Operation al-Fajr (New Dawn, also known as Phantom Fury) in November 2004. By the time that Sacco arrived northwest of Fallujah that December, the province was in full uprising. ${ }^{13}$

Rather than giving a solely military synopsis or analysis of the United States in Iraq, Sacco chose to simply report his observations in "Complacency

\footnotetext{
${ }^{10}$ Joe Sacco, "Complacency Kills," Guardian, 24 February 2005; and Sacco, "Complacency Kills," in Journalism, 74-81.

${ }^{11}$ Daniel B. Sparks, Small Unit Actions (Quantico, VA: Marine Corps History Division, 2007), 13-15.

${ }^{12}$ Williamson Murray and MajGen Robert H. Scales Jr. (USA), The Iraq War: A Military History (Cambridge, MA: Harvard University Press, 2003).

${ }^{13}$ William Langewiesche, "Rules of Engagement," in Nicholas J. Schlosser, ed., U.S. Marines in Iraq, 2004-2008: Anthology and Annotated Bibliography (Washington, DC: Marine Corps History Division, 2010), 140.
}

Kills," similar to the way Pyle presented the lives of common combatants during World War II. Sacco was embedded at Haditha Dam on the Euphrates River, the headquarters of the 1st Battalion, 23d Marines, five miles north of the city of Haditha. ${ }^{14}$ While Sacco was there in late fall 2004, the changes to both the province as well as within the Iraqi National Guard, the focus of his story "Down! Up!," were just starting to occur. Had he stayed longer, the stories may have taken on a different perspective when, in November 2005, what was classified as a civilian massacre of some residents of Haditha by U.S. Marines occurred. ${ }^{15}$ As it was, the stories that Sacco told and illustrated were still a reflection of what the soldiers and Marines felt while serving in Iraq. ${ }^{16}$ They along with many Americans were somewhat vexed by the fact that despite the declaration "mission accomplished" in May 2003, U.S. military personnel were not only still in the country but were experiencing losses well in excess of those during the initial invasion. ${ }^{17}$

Sacco also occupied a position that few had worked before, reporting in remote areas such as Haditha as opposed to Baghdad. His work took place before David Axe's War Fix, which dealt with the adrenaline rush of combat, as well as issues surrounding American forces in Iraq. ${ }^{18}$ However, Axe's work was not as focused on the military personnel in the area as Sacco's. Sacco's story "Trauma on Loan" was released around the same time as Brian K. Vaughan and Niko Henrichon's graphic novel Pride of Baghdad (2008). Both are set in Iraq and feature the pet lions kept by Saddam Hussein's oldest son, Uday Hussein. Pride of Baghdad, however, depicts what the lions saw while roaming through the rubble of Baghdad, giving the lions a voice to discuss the events around them. ${ }^{19}$

\footnotetext{
${ }^{14}$ Langewiesche, "Rules of Engagement," 137.

${ }^{15}$ Charlie Savage and Elisabeth Bumiller, "An Iraqi Massacre, a Light Sentence and a Question of Military Justice," New York Times, 27 January 2012; and Sacco, "Down! Up!," in Journalism, 82-97.

${ }^{16}$ Sacco, "Complacency Kills" and "Down! Up!," in Journalism, 74-97.

${ }^{17}$ Sacco, "Complacency Kills," 81.

${ }^{18}$ David Axe and Steven Olexa, War Fix (New York: NBM Publishing, 2006).

${ }^{19}$ Brian K. Vaughan, Niko Henrichon, and Todd Klein, Pride of Baghdad, deluxe ed. (New York: DC Comics/Vertigo, 2014).
} 
While both used the idea of Uday's lions, the latter was obviously fictional while Sacco's story related true events briefly featuring the lions.

\section{"Complacency Kills"}

The first of Saccos's stories focusing on the Iraq War was originally published as a comic extra for the Guardian. It illustrates the moral issues of vehicle-borne improvised explosive devices (VBIEDs, a.k.a. car bombs), the discussion of the war, and the comforts of home versus the harsh reality of life beyond the wire. Part of the story Sacco reported was about the thoughts of the Marines as well as the issue of when to use force (the idea of policing versus combat). This story explained that the Marines were, at times, unsure of the mission and the rules of engagement. Even when a potential adversary was acting in a manner that was clearly belligerent, the rules of warfare and response often meant that the Marines could do nothing until the individual committed an aggressive act, such as a shooting or car bomb detonation. By that time however, Americans might be either injured or killed and the culprits gone, only to resurface later.

Sacco incorporated the use of vehicle-borne personnel to respond to and pacify areas, like a kind of fire brigade, in "Complacency Kills." ${ }^{\text {"o }}$ Sacco described in detail the concept of the mobile action platoon (MAP) and the Humvees used to patrol the area. The mobility and power of U.S. forces and their armored vehicles offered some protection against small arms fire but MAPs also were magnets for attacks by insurgents. It was additionally a physical symbol of the disconnect between U.S. forces and the Iraqi people, with the idea that superior technology would naturally win the war. ${ }^{21}$

The story centers on the fact that the Marines of 1st Battalion, 23d Marines, often had problems identifying enemy combatants. The fear of attack or contact from what at first glance appeared to be civilians but could turn out to be combatants made the job all the more dangerous and frustrating. One of the consistent

\footnotetext{
${ }^{20}$ Sacco, "Complacency Kills," 74.

${ }^{21}$ Murray and Scales, The Iraq War, 259-60.
}

comments from both the media as well as some members of the military (albeit in very limited form) was that the mission in Iraq had no focus save that of placating politicians back home rather than doing what was necessary on the ground to pacify the area. In this regard, the comments were eerily similar to those of the Vietnam War. ${ }^{22}$

Servicemembers' thoughts about the war's purpose permeate the story. Two Marines, Corporal Chang (dubbed the "Iraqi lover") and Sergeant Johnson, debate how the Iraqis feel about the American presence. ${ }^{23}$ Often, the standard line from those on the ground was that the Americans were not wanted or were there to steal oil from Iraq or to otherwise push an agenda. Some military personnel and administration officials linked to the military have stated that the media had a deliberate bias against the war in Iraq specifically and the military in general. ${ }^{24}$ In this story, Sacco tried to relate the facts as he observed them without overtly expressing an opinion in favor for or against the war. He simply noted, as the name of the story indicates, that if the Marines did not remain vigilant at all times, their complacency could get them killed. For Sacco, the article was a way to show civilian readers that the war was real and that there were consequences if Marines let their guard down.

All of Sacco's stories in the Iraq series centered on the average U.S. servicemember, for example, Captain Kuniholm, who was described as a liberal $\mathrm{PhD}$ student. Sacco identifying Kuniholm's politics and education was significant because it goes against the stereotype of servicemembers: that they are undereducated and often politically conservative in their views. ${ }^{25}$ Political commentary at home was also in full swing by late 2004, when Sacco was in Iraq, as two presidential candidates' war records were argued. The 2004 presidential election centered on President George W. Bush's decision to go to war in Iraq due to Saddam Hussein's construction and storage of weapons of mass destruction. The discussion of Bush's war

\footnotetext{
${ }^{22}$ Herring, From Colony to Superpower, 909-10.

${ }^{23}$ Sacco, "Complacency Kills," 76-77.

${ }^{24}$ Murray and Scales, The Iraq War, 196.

${ }^{25}$ Sacco, "Complacency Kills," 75.
} 
record and that of his Democratic opponent, John Kerry, also brought to light the struggle of military service and its relationship to the political landscape. ${ }^{26}$

One of the problems that Sacco noted in this comic dispatch was that the enemy, in this case the anti-American forces, would not conduct a "stand-up" fight-that is, fight in a military manner. The tactics of asymmetrical warfare frustrated the American forces, who had shifted from aggressive military operations to conducting operations more akin to peacekeeping or police work. The Iraqis certainly knew that they would not defeat the United States using tactics of conventional warfare, so they relied on tactics that did work, waging guerrilla warfare. Insurgents did not wear uniforms, nor would they necessarily attack military targets; rather, they conducted operations that were meant to sow terror and confusion. In that regard, even neutral Iraqis would perceive the United States as being unable to stop the attacks and engaged in a conflict that would ultimately fail. ${ }^{27}$

"Complacency Kills" captures the frustration of U.S. forces toward the Iraqi population as well as the enemy. It explores questions about who one trusts and when a servicemember should fire a weapon. The constant second-guessing and sense of impotence at what could not be prevented were sources of frustration for military personnel. Questions that seemed to have clear-cut answers in the United States were not so easily answered in the fog of war in Iraq.

The Marines (and the U.S. armed forces in general) were often frustrated and sometimes, though unstated, battled a sense of failure about their mission

\footnotetext{
${ }^{26}$ In fall 2004, the Swift Boat Veterans for Truth openly attacked presidential candidate Kerry's Silver Star for valor, awarded for a combat situation in 1968. The organization claimed that his award for bravery was politically motivated, while others noted that while Kerry may or may not have deserved such an award, he was physically in the country of Vietnam serving when he could have sought some sort of exemption. Democrats questioned Bush's military record because he served in the Louisiana National Guard and his military records were missing several details about his assignment. These comments were debated and reported on extensively in all the media outlets. See Kate Zernike, "Veterans Rebut 'Swift Boat' Charges Against Kerry in Answer to Challenge," New York Times, 22 June 2008.

${ }^{27}$ Gerard Chaliand and Arnaud Blin, eds., The History of Terrorism: From Antiquity to Al Qaeda (Berkeley: University of California Press, 2007), $24-27$.
}

when Sacco wrote his first story, which Sacco continued to note in his other Iraq War stories. ${ }^{28}$ The city of Haditha was not particularly stable at that point, and sectarian violence as well as violence toward U.S. forces was on the rise. In "Complacency Kills," Sacco conveys the impression that the Marines feel more like cops or that they are hamstrung by the rules of engagement. But was this story intended to influence British readers against the mission in Iraq or to blame Prime Minister Tony Blair's administration for blindly following President Bush into a questionable war? The indication seems to be not overtly so. Though it was published in the Guardian, Sacco intended it for a mixed international audience. While he has lived in the United States and writes and illustrates primarily for a U.S. and Canadian audience, Sacco is Maltese, making him a British citizen by birth. ${ }^{29}$

Sacco noted that "Complacency Kills" could have been written about servicemembers during any time period. ${ }^{30}$ It showed the disconnect of soldiers from a "moral" war, such as World War II, where the goals were much more stated and direct, with what was going on in Iraq in 2004, where the situation was more convoluted. The Marines at the Haditha Dam had all the comforts of home, including a workout space, snacks, and television. The location could have been on any base around the world, further emphasizing the disconnect between the Marines and the locals.

Though not directly connected, there is a link between Haditha, the Marines, and Sacco's second Iraq War comic. Haditha was the site of a massacre of 24 unarmed Iraqi civilians on 19 November 2005 by eight Marines of Company K, 3 d Battalion, 1st Marine Division, who were convicted of unlawful killing. This incident further blurred the lines between combatants, civilians, and terrorists and made a complicated situation more difficult. ${ }^{31}$ For the U.S. military personnel fighting in the Haditha area who were the subject of "Complacency Kills," the frustrations of controlling or

\footnotetext{
${ }^{28}$ Steve Fainaru, "For Marines, a Frustrating Fight," Washington Post, 10 October 2004

${ }^{29}$ Duncan Campbell, "I Do Comics, Not Graphic Novels," Guardian, 23 October 2003 .

${ }^{30}$ Sacco, Journalism, 106.

${ }^{31}$ Langewiesche, "Rules of Engagement," 137-38.
} 
pacifying Iraq still made it seem as though the United States was hamstrung by the media, through either scrutinizing or demonizing any U.S. actions, as well as the rules of engagement that U.S. troops must follow. ${ }^{22}$ Given the 2004 abuses in Abu Ghraib prison that had already come to light, this was not unexpected. The abuse allegations, followed by the Haditha incident, seems to have made the next story Sacco wrote for the Guardian a natural follow-on piece.

\section{"Trauma on Loan"}

Another comic Sacco created for the Guardian in early 2006 centered on the issue of prisoners in Iraq and how misidentification might lead to further image issues for the U.S. military in Iraq. It also focused on whether the United States had contributed to either the implicit or explicit torture of Iraqis to gain information. Such interrogation methods and their results damaged U.S. credibility, especially during Iraqi elections.

Given the increasingly violent and elusive nature of the insurgency in Iraq, it was not surprising that American servicemembers felt considerable frustration and animosity toward the Iraqis or Afghans. The nature of insurgency often leads to acts of violence against locals, as it has in both Iraq and Afghanistan. The inability to clearly identify the enemy at times led to acts such as the abuse noted by writers Sacco, Axe, and Vaughan, among others.

The overall storyline seemingly exemplified the U.S. treatment of locals. In July 2003, businessmen Thahar Sabbar and Sherzad Khalid were arrested by U.S. forces. As with many aspects of the post-invasion occupation of Iraq, people often reported neighbors and others who they believed were colluding with Hussein's forces as well as those against whom they held a grudge (e.g., a neighbor who had slighted their family); this may have been the case for Sabbar and Khalid, but no formal evidence has been uncovered to that end. Sabbar and Khalid were detained by U.S. forces and, according to their accounts, subjected to the same sort of torture that was associated with the Mukhabbarat (Iraqi Secret Police) or Hussein's sa-

${ }^{22}$ Sacco, "Complacency Kills," 80. distic son Uday. ${ }^{33}$ Sacco depicted how Uday's use of his pet lions to intimidate prisoners was reportedly copied by the forces who held Sabbar and Khalid in "Trauma on Loan."

In 2005, the American Civil Liberties Union (ACLU) filed a lawsuit in the U.S. federal court system alleging that Donald Rumsfeld, then secretary of defense, authorized the use of torture to obtain information. ${ }^{34}$ The lawsuit had eight plaintiffs to represent the mass of detainees from both theaters of combat active in 2004 (four Afghans and four Iraqis), of which Sabbar and Khalid were a part. While Sacco did not actually describe the lawsuit that brought Sabbar and Khalid to the United States, it is important to note that the suit itself was the first against anyone in the Bush administration, and it noted that U.S. forcesthe U.S. Army as well as the Central Intelligence Agency (CIA)-were using torture to obtain information. ${ }^{35}$ In Sacco's story, the reader is introduced to other protests against the use of torture, such as the public display by Jennifer K. Harbury, who demonstrated in front of the White House, standing in what has become known as the Abu Ghraib pose: arms extended and a black hood over her head. Harbury's Guatemalan husband was tortured in the late 1980 os by a CIA-trained group, and her protest was to note that the U.S. government was doing it again. ${ }^{36}$

The initial comments on the use of torture were dismissed by Rumsfeld and other administration officials as pedantic and weak. It has often been noted that when dealing with religious zealots or others willing to die for their cause, the rules change and the adversary's willingness to commit suicide for a political end meant the use of torture was a necessity for gleaning information to prevent future attacks on U.S. targets. ${ }^{37}$ The wider issue that Sacco addressed in "Trauma on Loan" was the many different forms torture took,

\footnotetext{
33 Sacco, "Trauma on Loan," in Journalism, 98-105.

34 "The Case against Rumsfeld," ACLU, accessed 15 November 2019.

35 Committee Study of the Central Intelligence Agency's Detention and Interrogation Program (Washington, DC: Senate Select Committee on Intelligence, 2014).

${ }^{36}$ Sacco, "Trauma on Loan," 104.

37 Committee Study of the Central Intelligence Agency's Detention and Interrogation Program, 155-58; and Chaliand and Blin, The History of Terrorism, 360-61.
} 
from debasing a person through either simulated rape with a water bottle and interrogation of naked male prisoners by females to beatings with clubs. Sacco further describes the borderline sadistic actions of a U.S. soldier taunting Iraqi prisoners and forcing a prisoner to debase himself for cigarettes. While many pundits countered by arguing that Saddam Hussein habitually used means of torture that were far worse, the idea of torture was one that could not be ignored in regard to U.S. policy. ${ }^{38}$ Sacco noted that his attempts to gain information from Sabbar and Khalid caused them pain by forcing them to relive events and were therefore a form of torture for them as well as for Sacco, who needed the information to corroborate the events. Sacco noted that while he was trying to ascertain the truth of the matter, it was often vexing and ultimately unsuccessful.

From this story, one could easily conclude that the U.S. military was no better than Saddam Hussein in its use of torture to gain information, albeit in less obviously violent forms. At the same time, Sacco noted that he could not get a lot of information to later corroborate the accounts of arrest, or of the specific facts by which the men were detained. The larger question one takes away from reading "Trauma on Loan" was what sort of deleterious effects were left on the Iraqi people, and what of the future? Sacco did not come to any sort of conclusions, but his underlying tone was that the decision to go to war, rather than the immediate results of the actions of the Marines on the ground, was flawed.

\section{"Down! Up!"}

The final story in Sacco's Iraq War series was published in Harper's magazine in 2007. "Down! Up!" follows the 1st Battalion, 23d Marines, again stationed at Haditha Dam, focusing on the training of Iraqi National Guard (ING) forces to prepare them for the United States' exit from Iraq. However, the story demonstrates the ineffective nature of the training from the viewpoint of the Marines.

\footnotetext{
${ }^{38}$ Committee Study of the Central Intelligence Agency's Detention and Interrogation Program; and Susan B. Glasser, "Scars Document Torture by Hussein Regime," Washington Post, 19 April 2003.
}

Two Americans-Marine Reserve Sergeant Tim Weaver and Navy Reserve Petty Officer Second Class Scott Saba-are featured, both involved in the training of the ING personnel. Their training methods seemed harsh at first glance, consisting primarily of physical exercises akin to those practiced in U.S. training camps, but it was intended to keep people alive. The story explores the underlying distrust that existed between the Iraqi trainees and U.S. forces. The training in fact varied little from that used by U.S. forces, except for one key difference: level of commitment to military service. The U.S. forces were professionally trained as a truly volunteer military, as opposed to Iraqi volunteers whose level of commitment might be widely varied or even nonexistent (that is, service may have been forced); and that the standards of training involved different levels of physical fitness. 39 One of the larger problems in Iraq after Saddam Hussein's overthrow was that the ING were often targets of violence from a variety of sources. As one ING recruit named Qaid noted, "If you work for the Americans, the mujahedeen will kill you; if you work for the mujahedeen, the Americans will kill you; if you stay home you won't earn any money."40

The larger issue for both the American trainers and the ING trainees was a level of professionalism. In Sacco's story, the overall position of the U.S. forces was that the ING needed to take on training and their military duties-such as patrolling, interdiction, and counterinsurgency-seriously, lest they become easy targets for anti-U.S. forces. Whether the Americans should have conducted the war in Iraq in 2003 was no longer of concern; it was simply a matter of learning the lessons to keep ING trainees alive when their forces took over Iraq's security activities. The trainers depicted in the story noted that the Iraqis were not ready to conduct their own operations. The same

\footnotetext{
39 The use of the term volunteers is spurious here as it denotes that the Iraqis may have been forced to join as a way to avoid some sort of punishment from civilian authorities or due to a lack of other more applicable or suitable jobs in their area. While volunteers in the sense that they joined willingly, as opposed to some form of conscription, these troops were not always enthusiastic. Sacco, "Down! Up!," in Journalism, 82.

40 Sacco, "Down! Up!," 97.
} 
could have been said of the Afghan National Army troops as well.

The one issue of note in "Down! Up!" is that both groups were not active duty combatants, but Reserve forces pulled into a full combat role. One of the complaints from many Americans was that despite the official end of the war after a short seven weeks, formal hostilities did not end; the conflict merely shifted from formal combat operations to an insurgency that required more American troops for the role of training and advisement. The need for extra American troops required activating a considerable number of U.S. armed forces Reserve and National Guard units. ${ }^{41}$ "Down! Up!" again featured the Marine reservists of 1st Battalion, 23d Marines, in Haditha in the fall of $2004 \cdot^{42}$

The Iraqis were in a similar situation. They were not full-time soldiers, nor did they expect to be utilized as such. The ING was meant to offer additional security to the Iraqi national police forces. The idea was that the old way of corruption and familial ties could be broken, and a new professional force could be instituted, both in Iraq and Afghanistan. However, many of the ING recruits were from large, poor families with limited opportunities to do anything other than become a soldier. ${ }^{43}$ Sacco noted the Iraqis' perception that the Americans were angry at them for being lazy and unmotivated. ${ }^{44}$ There are several reasons this could have occurred.

First, the Iraqis had been effectively in a state of war or crisis for close to 25 years at the time Sacco wrote "Down! Up!." Between the brutality of the IranIraq War, the Kuwait invasion and Operation Desert Storm, the sanctions, the secret police, and Operation Iraqi Freedom and the sectarian violence it unleashed, it was not surprising that there were issues of morale, motivation, and training. ${ }^{45}$

\footnotetext{
${ }^{41}$ Sacco, "Complacency Kills," 77; and John Sloan Brown, Kevlar Legions: The Transformation of the U.S. Army, 1989-2005 (Washington, DC: Center of Military History, U.S. Army, 2008), 281.

${ }^{42}$ Sacco, "Down! Up!," 82; and Langewiesche, "Rules of Engagement," 137.

${ }^{43}$ Sacco, "Down! Up!," 84.

${ }^{44}$ Sacco, "Down! Up!," 95.

45 "Old Iraqi National Guard, 2004-2005," Global Security (website), accessed 15 November 2019 .
}

Second, the prevailing assumption among the ING was like that of the National Guard in the United States: they were not full-time soldiers and therefore would not be needed on the front lines. The Iraq War changed that for both sides.

Third, the tribal nature of Iraqi as well as other Arabic societies meant that ING members' loyalties were divided. As the groups within the country are often linked through blood ties and familial obligations, one's immediate group takes precedence. Finally, add to that the sectarian violence connected to the branches of Islam, Sunni, Shi'a, and Kurd, and these cultural, societal, and national divisions led to further violence. ${ }^{46}$ Sacco's story explained that the U.S. concept removed the ING members from their communities for training and reunited them in another part of the country, where the idea of blood ties, and possible feuds, would supposedly dissipate. This idyllic theory of the training and integration process was supposed to allow more democratic ideas to flourish and subsume family ties and local identity. This approach did not bear any fruit. Instead, the distrust and violence remained.

The 6oth ING Battalion was disbanded around the time of the initial reporting and was absorbed into the Iraqi Army by the time Sacco's story was published in Harper's. The idea that the Iraqis were unable or unwilling to conduct their own patrols was important to note as well, as it demonstrated the lack of trust-others would say lack of competency-of the troops slated to replace U.S. forces. Even the Marines noted that the necessity of Iraqi involvement was paramount to any sort of U.S. withdrawal. The idea of Iraqi readiness was also noted in the analysis by military officials at the time. ${ }^{47}$ In summation, it was not those who carried out the policy for whom Sacco held negative feelings or ideas, but for the U.S. policy that seemed flawed.

\section{Conclusion}

Given that realistic art is often a necessity in modern comics, a reader with a working knowledge of the world and a visual familiarity with military hardware

\footnotetext{
${ }^{46}$ Small Unit Actions, 13; and Schlosser, U.S. Marines in Iraq, 13.

${ }^{47}$ Langewiesche, "Rules of Engagement," 142.
} 
wants a story and images that are at least fairly accurate and an authentic story that resonates. For an informed reader, stories such as these may be a first step toward seeking out more detailed monographs on the conflicts written by the combatants. Illustrative stories such as Sacco's may also discuss lesser-known aspects of a conflict, such as the political background that led to it. The merging of journalism with the comic book format may also mean a future reevaluation of conflicts and the reporting thereof. What is most compelling is how Sacco's work brings a journalistic sense to the comic book field. This new style of journalism should be seen as biased due to its political leanings or vantage points, but at the same time as a springboard for further exploration of the events depicted in the story. As has been shown in the stories, Sacco shows an empathy for the Marines with whom he was embedded, but he also may show some bias against the reasons the United States entered a war in Iraq. Sacco's work fits in the first draft of history, but it is still from a journalist's point of view. If combined with more detailed accounts, and even unofficial comic sources such as Max Uriarte's Terminal Lance, perhaps a more accurate picture emerges.

For anyone reporting on combat or even those writing on it, the events of the moment are often not what is recorded by historians. Following the use and manipulation of the media in wartime for political goals, the new era of instant communication is a realm in which information can be manipulated, omitted, or forgotten. Innuendo becomes the norm and the events become clouded by the reporter as well as the witnesses. Much of this stems from the fact that the lines seem to blur between the combatant and the reporter, especially when the latter is embedded with the former. However, the role that Sacco occupies is one that allows for personal reflection as well as time to check the facts. Regardless, Sacco reported on the general attitudes of the U.S. forces with whom he was embedded during the Iraq War and his stories point to the idea that the war has had, at best, a neutral impact and at worst has been a public relations disaster due to actions that have contributed to the general mistrust of U.S. policy in the region. The larger question might be how the United States can alleviate that damage.

Sacco is to be commended for his work in Iraq and for being willing to tackle subjects that many in the United States simply do not understand, either in its history or the combat encountered by those who serve a tour there. His medium is one that does not allow for the instant reporting that has become the norm. His works captured a part of the conflicts in a new form of historical documentation that offers a unique perspective on the struggles and frustrations encountered in Iraq. His work provides a means for people to form a greater understanding of aspects of combat operations in the post-9/11 world. As with any first draft of history, a review of the stories reported at the time might yield a different reading of events, and these initial observations might well have changed as more information and other reports surfaced. Regardless, it is a way to capture in visual form the moments and ideas in a wider conflict. 


\section{REVIEW ESSAY}

\section{Keith D. Dickson, PhD}

Charging Up San Juan Hill: Theodore Roosevelt and the Making of Imperial America. By John R. Van Atta. (Baltimore, MD: Johns Hopkins University Press, 2018. Pp. 224. \$49.95 cloth; \$22.95 paperback and e-book.)

In Command: Theodore Roosevelt and the American Military. By Matthew Oyos. (Lincoln, NE: Potomac Books, 2018. Pp. 456. \$36.95 cloth.)

If he were president today, Theodore Roosevelt would fully endorse the 2018 United States National Security Strategy, which turns America's efforts toward great power competition: "The United States will respond to the growing political, economic, and military competitions we face around the world. China and Russia challenge American power, influence, and interests, attempting to erode American security and prosperity." During his own presidency (1901-9), Roosevelt faced great power competition from Japan, Great Britain, and Imperial Germany, all attempting to challenge American security and prosperity. Although the United States was a rising power in Roosevelt's time, not the superpower it is today, Roosevelt would likely tread today as deftly as he did a century ago in terms of foreign policy and military strategy.

John R. Van Atta and Matthew Oyos offer exceptional insights into Roosevelt's life and times. Van Atta explores the cultural and societal aspects of Roosevelt's arrival on the national stage, first as a war hero in the Spanish-American War and then as a candidate for high office. Oyos follows the same path, examining how Roosevelt as commander in chief approached modernizing the American military for the new burdens of a rising global power. Van Atta's Charging Up San Juan Hill: Theodore Roosevelt and the Making of Impe-

Keith D. Dickson is a professor of military studies at the Joint and Advanced Warfighting School, National Defense University. He is the author of No Surrender: Asymmetric Warfare in the Reconstruction South (2017).

${ }^{1}$ Donald J. Trump, National Security Strategy of the United States of America (Washington, DC: White House, 2017), 2. rial America offers a perspective on how the United States transitioned from a country driven to build a new nation after the Civil War to one on the verge of empire-building, while outlining the social and intellectual trends that shaped Roosevelt's youth and early manhood. One important trend the author notes was an uncertainty about America's future. Veterans of the Civil War generation decried what they perceived to be the weakness and passivity of the new generation of American men. Urbanization and immigration in the 2o years after surrender at Appomattox Court House, Virginia, had combined to weaken the American f1ber. The closing of the frontier had also brought about a stagnation of American culture, which would no longer be renewed by the contest to tame new lands. More importantly, the byproduct of this struggle-the proud, independent, free citizen-would no longer exist to renew and reinvigorate American life.

Using this background, Van Atta ties the American cultural search for moral and spiritual regeneration to imperialism, the quest for new opportunities beyond the country's continental borders. He declares that all imperialism reflects "deeply ingrained values at an ideological core" (Van Atta, p. 3o). U.S. imperialism was tied to sustaining American character and virtues and that to sustain these essential elements of American life, Hawaii, the Pacific, and the Caribbean beckoned. Competition with other great powers was inherent in this need for expansion, yet war was not to be feared; instead it was to be welcomed as a tonic to revitalize a dissolute culture. It is this background that allows Van Atta to explain why the United States 
fell into a war with Spain in 1898. Van Atta points to the romance, glamour, and mythic image of the American West and the central figure of the cowboy as the ultimate source of the Rough Riders, the volunteer cavalry unit that Roosevelt assembled to fight in the war. Here, cultural and imperialistic trends merged to create the perfect instrument to cure the perceived flaws of America.

As Van Atta notes, the Rough Riders were organized as something of an experiment to show that all Americans, "whatever their political, social, or sectional differences, still had greatness in them" (Van Atta, p. 67). Curiously, the actual account of the famous charge Roosevelt's men participated in is heavily downplayed. Roosevelt is portrayed as an accidental character in a much bigger drama populated by African American troopers of the Army's gth and 1oth Cavalry Regiments, who, the author grimly notes, received little attention in the contemporary accounts of the battle. Although Van Atta justifies this comment by referencing modern military historians who tend to give the 1oth Cavalry (along with Roosevelt's unit and other volunteers) the primary credit, the footnote supporting this assertion only references one modern source and two contemporary sources. It is a point he returns to several times, and by the book's conclusion, it becomes a distraction.

The Spanish-American War, indeed, achieved its unstated goals-to restore American confidence in itself as a vital nation and to excite interest in taking on a greater role in the world. The Rough Riders themselves came to personify in the public mind a combination of sterling American patriotism and the finest qualities of the American fighting spirit, a validation Roosevelt intensely valued his entire life. As a rising national political figure, Roosevelt clearly accepted the challenge that American victory over Spain presented. The challenges were many-winning the war was easy, but the future peace and stability of Cuba and the newly acquired Philippines would provide a test of the American spirit and will. Such challenges, he proclaimed, were worthy of America as a great nation. Roosevelt parlayed his hero status into political success, becoming governor of New York in 1898. By
1900, there was no doubt that Theodore Roosevelt was essential to the Republican ticket as the candidate for vice president. The dynamo would balance the taciturn incumbent president William McKinley and outshine the Democrat's powerhouse candidate William Jennings Bryan. Roosevelt consciously sought to personify the American spirit characterized by the masculine ideal of physical and moral courage, consciousness of duty, a strenuous engagement with life, and a desire to achieve great goals.

Van Atta currently holds the Oaklawn Chair in American History at the Brunswick School, a college preparatory day school in Greenwich, Connecticut. It appears that a number of his comments throughout the book reflect both his teaching style and the environment of the modern secondary school classroom. In numerous places, Van Atta seems compelled to comment on certain phrases or accounts in the historical source documents in what appears to be an attempt to mollify modern sensibilities. A few examples will suffice: "Although billed as an 'all-American' fighting force, the Rough Riders would pass no multicultural muster of today" (Van Atta, p. 67). The author also makes it clear that no African Americans, women, Asians, or Southern or Eastern Europeans were in the unit, although he does dutifully note it did include Catholics, Jews, and Native Americans. Likewise, Van Atta's presentation of Roosevelt's admiration for the physical build and hardy demeanor of two members of the unit brings a quick clarification from the author, who states that Roosevelt's observation should not be thought of as "a kind of homoerotic attraction," but instead, of Roosevelt's own obsession with body building as a young man (Van Atta, p. 94).

The author's broad research on the social roots of imperialism is impressive. His research on the background of the Cuba campaign is also solid. All in all, Van Atta explores interesting aspects of American life at the turn of the century, providing a very useful insight for explaining the basis for how and why America would rise to become a great power. Theodore Roosevelt became the model for the American spirit and then became the leader of a country transformed. The numerous influences in his life-the war 
for the Union, the great West, a strenuous life, as well as his patriotism and a belief in personal courage and duty-created an unshakable belief in America's destiny to lead the world. But Van Atta infuses his writing with a vague tone of disapproval of Roosevelt, who emerges from these pages as a war-crazy volunteer, an Anglo-Saxon supremacist, and a man who held onto outdated ideals far too long.

Van Atta's book is a valuable prelude to a far more engaging account of Theodore Roosevelt as commander in chief. Matthew Oyos, author of In Command: Theodore Roosevelt and the American Military, takes on his formidable protagonist with verve and vigor. Roosevelt believed the military represented the vitality of America and the American people and also trusted that the military instrument of national power could be exercised adeptly to protect the nation's global strategic interests. Oyos agrees with Van Atta's view that the combat service of the Rough Riders in the Spanish-American War had a deep influence on Roosevelt's concept of the American military. He never lost his high sense of romantic attachment to military life, which, in turn, influenced his approach to military matters as president.

Oyos echoes Van Atta's thesis that Roosevelt reflects the predominant intellectual trends of his age, solidified by his experiences in the West as a rancher and in battle as a military commander in Cuba. "For Roosevelt imperial ventures combined the best of both economic and martial worlds," Oyos observes. "Overseas expansion would represent economic challenge and opportunity, court the twin risks of danger and death, and breed a sense of larger responsibility and duty that could only strengthen civic virtues and military qualities" (Oyos, pp. 41-42). He finds in Roosevelt an interesting intersection of nineteenthcentury thinking about individual striving for personal and moral perfection with a twentieth-century predilection for institutions and systems to bring about lasting reform (Oyos, pp. 53-54). Roosevelt held government service in high esteem as a mark of both moral duty for men of his class as well as a reflection of patriotism. As assistant secretary of the Navy, he was fascinated by both the actual and symbolic pow- er of armored warships-especially battleships-and stressed the importance of wartime preparedness. This experience gave Roosevelt his first exposure to a large bureaucracy, and as chair of the Naval War Board, he was responsible for addressing issues of naval strategy. While Van Atta largely views Roosevelt's experience in Cuba as something of a hyper-masculine fantasy come true, Oyos agrees that "the hard reality of war" had little effect on him, but he goes further to show that Roosevelt was a perceptive and thoughtful observer who took valuable lessons away from the battlefield concerning the conduct of modern warfare-especially charging an entrenched enemy equipped with modern rifles-command and control, and the importance of capable senior leaders (Oyos, pp. 82-85). As governor of New York, Roosevelt demonstrated his lack of faith in the state guard, based both on his experiences in the New York state guard as a junior officer from $1880-83$ and in dealing with the political fallout from the poor performance of the officers of the 71st Regiment of the New York state guard in Cuba. During his short tenure, he pushed for a national effort to reform all state guard units into an operational reserve. Other political demands brought him to the vice presidency, and then, by unexpected and tragic circumstances, to the nation's highest office.

Roosevelt was by inclination a hands-on leader and an enthusiastic promoter of military power as a reflection of American pride and superiority. One of his priorities was the creation of a hard-hitting battle fleet. International trade was making the United States wealthy and influential, but such economic power had to be backed by significant military power. As Oyos notes, Roosevelt's involvement in naval operations during his presidency marked a new role for the commander in chief. Every president since Theodore Roosevelt has had to be immersed in affairs of national security, while also gaining a familiarity with military technology (Oyos, pp. 143-44).

The Marine Corps shuddered under Roosevelt's intense dislike, and officers in the Army found that careerism was anathema to the president. He demanded that only the best prepared, most fit, and most 
capable be promoted to senior leadership positions. John J. Pershing was this kind of leader, and Roosevelt ensured that he was promoted ahead of his peers. Pershing would soon find himself commanding the American Expeditionary Forces in Europe in World War I, one of the most important command responsibilities of any American officer in history. Although Congress did not enact Roosevelt's desired reforms, the president and his secretary of war, Elihu Root, did have a lasting influence on changing the officer personnel system toward merit rather than seniority. Roosevelt also sought efficiency and preparedness in the Army and Navy. In his view, modern war demanded prepared forces, and the commander in chief required land and sea units to conduct exercises and maneuvers to hone fighting skills.

His exposure to strategic planning and his experience in Cuba made Roosevelt a vigorous proponent of a general staff system, both to conduct contingency planning as well as support wartime operations. In 1903, Congress presented the president with a bill to create an Army general staff. As he observed the campaigns of the Russo-Japanese War of 1904-5, the president could not resist bedeviling the new general staff by delving into the small details, requesting studies and reports on different rifles and bayonets, even as he provided perceptive guidance as commander in chief on ensuring the staff studied the lessons of the war in Asia in terms of their applicability to the modernization of American ground forces. Several potential crises in China, Venezuela, and Cuba led Roosevelt to consider the role of U.S. military power as a tool of diplomacy. He demonstrated caution, unwilling to commit American power unless it could be sustained for as long as needed. The general staff came of age during this time, providing the president with outlines of contingency plans, staff studies, and readiness assessments.

The Militia Act of 1903 did move state guard units closer to federal oversight, but nothing close to what Roosevelt had advocated as governor. The president was content to let Root do much of the hard work with Congress and accept the final legislative outcome. Oyos points to Roosevelt's bias against the guard based on his own experiences and his belief that the guard had "become little more than instruments for dispensing patronage" (Oyos, p. 177).

Roosevelt was a practical politician who measured success through small victories rather than sweeping change. Although he pushed hard for a general staff organization for the Army, an institution he firmly believed needed structural reform, he was less driven to do the same for the Navy. As Oyos points out, congressional funding for a large battle fleet was more important to him than structural reform within the Service (Oyos, pp. 221, 229). Sending the U.S. battle fleet of 16 ships on a world cruise in 1907-9 was pure Roosevelt: a demonstration of American power at a time when the battleship was the prime symbol of military strength, painted white as a symbol of peaceful intent, so that every major power took notice of the fleet's potential as a warfighting instrument. Japan, for example, would be both calmed by friendly rhetoric, while at the same time dissuaded from challenging the United States in the Pacific.

Roosevelt "jealously guarded his prerogatives as head of the armed forces, perhaps more than any other part of his executive power" (Oyos, p. 269), and Oyos effectively portrays how the president influenced the evolution of the Army and Navy toward supporting a new strategic environment characterized by global interests that demanded the new roles for American military power. As a progressive reformer, he modified these institutions to make them more responsive to the commander in chief. His high sense of moral purpose and unbridled enthusiasm for grand projects in the interest of the nation marked his presidency. Despite his overexuberance in delving into details, Roosevelt created the basis for the modern defense structure that exists today. Oyos has written a wellresearched and engaging book that illuminates an important and largely unappreciated aspect of Theodore Roosevelt's presidency and his enduring contribution to national defense. 


\title{
BOOK REVIEWS
}

\author{
Seth Givens, PhD
}

Sand and Steel: The D-Day Invasions and the Liberation of France. By Peter Caddick-Adams. (Oxford, UK: Oxford University Press, 2019. Pp. 1,072. \$34.95 cloth.)

Ever since Cornelius Ryan wrote his classic The Longest Day in 1959, the Allied invasion of Normandy during World War II has captured the imaginations of budding historians and been etched into popular memory as more a social reality than a historical event. It also has been a perennial favorite of publishers, who see D-Day as a distillation of the American GI's accomplishment in Europe: the culmination of years of preparation and planning, the beginning of the end for Nazi Germany, and the rolling up of tyranny across Western Europe. But how does one tell the story in such a way that readers pick up one particular book and not one of the countless others? Peter CaddickAdams, an accomplished scholar on World War II who has held a number of positions in academia and the British professional military education system, believes the solution is thoroughness.

His task is large. Caddick-Adams set out to provide a balanced perspective of D-Day, including views from the British, Canadians, and Americans who established a beachhead at Normandy to the Germans who attempted to defend against it. His thoroughness is not artifice but an argument in and of itself, as one of his objectives is to remind the reader that Operation Overlord was an Allied undertaking, not individual British and American operations that simply happened to occur on the same day. His argument, too, is that it was a monumental endeavor, and thus the story of a generation born around the globe in the 1910 s and $1920 s$. Such fastidiousness is measured

Seth Givens is a historian with the Marine Corps History Division. He is currently preparing the official Marine Corps history of Operation Iraqi Freedom. usually in page count, and Sand and Steel makes a declarative statement with its robust 9oo-plus pages, including detailed citations that scholars and students will appreciate. To tell a story this size, Caddick-Adams chose to divide his book in two parts, evenly balancing planning and the operation itself.

Part one, called "Preparation," covers all aspects of the groundwork for the invasion, building up to the moment before it began. This is therefore not a work that gets the usual D-Day treatment, which typically begins aboard the stomach-churning, pitching decks of landing ship, tanks (LSTs), or inside the vibrating fuselage of a Douglas C-47 Skytrain transport aircraft. Instead, Caddick-Adams starts in 1940, with French Army brigadier general Charles de Gaulle's radio address to his countrymen from London, notifying them that he had established a government-in-exile and calling on all French who were capable to come to Britain or resist the German occupation at home. From there, the author touches on many topics, from the social and cultural aspects of American and Canadian soldiers and airmen based in Britain to the sometimes-heated discussions that took place among the Combined Chiefs of Staff.

The effect of all this background is that it provides context for the reader about how mammoth an undertaking Operation Overlord was. Often lost in histories of D-Day is that it was not a given that the invasion of Europe would happen where and when it did. Months of arguments about strategy and logistics had to take place first. Once the decision was finalized, the individuals who came from every corner of each Allied country began training based on the area 
of Normandy where they would land, and with that came the loss of a surprising number of lives during exercises. Also seldom mentioned in many works on Overlord are the herculean efforts it took to stage the troops and materiel in Britain. After all, every aircraft, tank, jeep, rifle, mortar round, and boot the Americans used had to be flown or shipped from the United States.

The way in which Caddick-Adams tackles the first half of his work makes it somewhat of a hybrid in terms of organization: loosely chronological in arrangement but topical in content. For example, he discusses the American aviators who arrived in Britain in 1942 in one chapter, highlighting what they saw and experienced, and then does the same for the ground troops who made the trip by boat two chapters later, with many of the same conclusions. Trying to balance the progression of time with topical discussions unfortunately makes sections of this book redundant, and a reader attempting to discover, say, the relationships between U.S. aviation servicemembers and the local population will have to search for information over several chapters. There is also the effect of bouncing back and forth between 1942 and 1944 to discuss many topics. Still, Caddick-Adams does a masterful job synthesizing a growing literature from the past two decades on aspects of the war other than the fighting.

While the first half of the book is split between social, cultural, diplomatic, and military history, part two, called "Invasion," is purely operational and focuses only on 6 June 1944. It is here where CaddickAdams hits his stride, writing a gripping narrative that seamlessly weaves together an impressive amount of primary and secondary sources, from interviews he and others conducted to unit records from multiple archives and the sizable literature on Normandy. His discussion of Operation Neptune, the naval side of the operation, is one of the better on offer, a conscious decision on the author's part to remind readers that the U.S., British, Canadian, and French navies did much more on D-Day than just ferry troops across the English Channel.

To piece together what took place that day,
Caddick-Adams eschews standard chronological storytelling and uses instead the novel idea of tracking events from west to east. The arrangement means that he organizes his chapter by beach-Utah, Omaha, Gold, Juno, and Sword-and therefore, by default, by unit. He should be commended for attempting a new way to relate the events of 6 June, but it takes a toll on the reader. Events are repeated, as he has to tell a different perspective of the same story over several chapters, as was the case in part one. Moreover, context for events sometimes appears 100 pages beyond when it was first needed. The particulars of the airborne and amphibious assaults suffer the most from this issue, distorting time and making an already intricate story more complex. There is, however, a positive consequence of telling the story from west to east. The reader is subtly reminded how the environment acted as an invisible hand that shaped the battle. In spite of all the Allies' planning, they could not control currents and wind. For many of the assault waves, their fortune or misfortune rested on where they landed on Normandy: some arrived where they were supposed to, but right into the teeth of the waiting Germans, while others were blown off course, saving them from the destruction their comrades were experiencing a few hundred yards away.

As part two unfolds, it is clear Caddick-Adams's objective is to dismantle the myths that surround 6 June. Among them are the oft-repeated tropes of aircrews dropping their paratroopers too early or too low and coxswains being forced to land closer to the shore at gunpoint. Caddick-Adams does an impressive job tracking where many of these myths began and then marshaling evidence to dispel them. He also criticizes individuals where warranted, taking military historian Samuel Lyman Atwood Marshall to task for inaccuracies and mythmaking and author Cornelius Ryan for dramatizing events such as the fight on Pointe du Hoc that became subsequently codified in popular memory.

Sand and Steel is the second book in the series, though the work that precedes it is on the Battle of the Bulge (Sand and Steel, 2014). In some regards, 
Caddick-Adams has been building up to this book, as he has been studying Normandy since he first visited as a boy in 1975, making it a labor of love. Despite the peculiarities of arrangement, the casual reader will enjoy Sand and Steel because of its high-quality narra- tive, and the scholar will appreciate it for its thorough research. The adjective authoritative is bandied about today perhaps too freely, but this work deserves such a descriptor. 


\section{Colonel Douglas Nash Sr., USA (Ret)}

The First Day on the Eastern Front: Germany Invades the Soviet Union, June 22, 1941. By Craig W. H. Luther. (Guilford, CT: Stackpole Books, 2018. Pp. 504. \$39.95 cloth.)

The First Day on the Eastern Front is an unusual book. It stands by itself in its treatment of a single day: the first day of Operation Barbarossa, the largest land invasion in history, during World War II. Even more noteworthy, it covers the actions of both sides-the Axis forces led by Nazi Germany and the forces of the Soviet Union-in minute detail, ranging from the actions of individual soldiers at the tactical level; to operational decisions made by commanders at army, army group, and front level; and all the way up to the grand strategic level, where decisions were made by Adolf Hitler and Josef Stalin that influenced the outcome of the war. Breathtaking in scope and meticulously detailed, Dr. Luther's new book has done a great service to the historiography of the Russo-German War in its depiction of the first day of the most savage and bitter war the world has ever seen.

The author does not take sides, choosing instead to maintain an unbiased, objective point of view, though never shying away from the unpleasant aspects of this life-and-death struggle. He covers not only the first day of the invasion as a series of discrete events but also devotes considerable space in his opening chapters to presenting and analyzing events leading up to Hitler's decision to widen the war and launch a surprise attack on his erstwhile ally. Concerning the few days leading up to the invasion, Luther focuses his historian's eye on the preparations of individuals, companies, battalions, regiments, and divisions as they move into their assault positions, as well as what the men on both sides were thinking about on the eve of battle and what for many would be their last day alive.

Douglas E. Nash Sr. served as head of Histories Branch, Marine Corps History Division, from 2016 to 2019.
Then, on 22 June 1941, 3 million Axis soldiers supported by thousands of tanks and aircraft struck against an unprepared Soviet Union along a border stretching from the Black Sea to the Baltic. Luther focuses his attention on the actions of the Axis field armies, panzer groups, and army groups taken once the attack commenced, ranging from Army Group South to Army Group North, expertly covering all of the tactical action in between. He then ends this portion of the book with a précis of the actions that took place that day. Soviet leaders, their tactical array, and their initial responses are also minutely detailed, incorporating an aspect of the war that has been insufficiently covered by Western historians.

Despite the myth of being a "Stumbling Colossus," the Red Army fought far better than described in earlier historical accounts, though it was hampered from the outset by unrealistic directives emanating from the Kremlin. The Luftwaffe's air campaign also receives its fair share of attention in a chapter dedicated to its success that day, wherein it virtually destroyed the Red Air Force on the ground before it could react. The SS death squads do not escape notice either, and while they had not yet had the opportunity to express their murderous intent on that first day, their mere presence behind the field armies serves as a preview of the horror they would soon unleash.

Military professionals would benefit from studying Luther's book, particularly regarding his detailed analysis of the various political, geostrategic, and logistics factors that strongly influenced the months and weeks leading up to the beginning of the campaign. Readers will learn that Hitler's Wehrmacht did not deliberately underestimate the logistics requirement of the campaign, as is commonly believed, but rather that the vaunted German general staff esti- 
mated that the invasion and subjugation of the Soviet Union would be completed by harvest time, thereby requiring no longer-term plan than what was originally contemplated. That the fighting would drag on well beyond September 1941 was something that the German general staff had simply not contemplated. "Victory Disease," a result of their successful campaigns in Poland, Norway, Denmark, France, Holland, Belgium, and Yugoslavia, and the belief in their own infallibility had become so deeply ingrained in their thinking that Hitler, his generals, and the Wehrmacht's rank and file could imagine no other outcome of their invasion than a rapid and total victory. Such hubris was to prove their downfall and serves as an object lesson to the armed forces of today and of the future, regardless under which flag they serve.

Finally, Luther concludes the book with a sum- mary and analysis of the day's events and offers a glimpse into the future course of the "Most Destructive War in History" as well as the ultimate failure of Barbarossa. The book itself is a pleasure to read, never descending into overly pedantic or academic jargon, and should appeal to both the layman and professional historian alike. The extensive appendices are an added bonus, in its provision of actual field orders directing the invasion, orders of battle, and various Soviet commissar orders. Finally, a 16-page photographic essay is included, with images depicting key leaders, weapons, and troops of both sides in action, but this is merely icing on the cake. Readers will quickly realize that this new treatment of the war has raised the bar for future accounts; hopefully, other authors will rise to the challenge and seek to elevate the level of discussion in future works. 


\section{Zachary M. Matusheski, PhD}

Eisenhower: Becoming the Leader of the Free World. By Louis Galambos. (Baltimore, MD: Johns Hopkins University Press, 2018. Pp. 296. \$26.95 cloth and e-book.)

William Shakespeare once wrote that "brevity is the soul of wit." In the widely celebrated The Elements of Style, E. B. White and William Strunk reminded readers of the value of that observation when they proved that shorter sentence construction makes for better writing. Louis Galambos followed in that vein in his book Eisenhower: Becoming the Leader of the Free World. In fewer than 300 pages, Galambos offers a biography of President Dwight D. Eisenhower that focuses on leadership lessons. At times, Galambos is successful, providing helpful information on Eisenhower's childhood, but elsewhere his drive for a short book leaves out critical subjects during Eisenhower's presidency. Galambos's strong writing style and familiarity with his topic make this a good book for readers beginning to explore Eisenhower's life, but the parts the author omits limits the book's usefulness to students of the 1950s, the Cold War, or the military history of the twentieth century.

For Eisenhower-era scholars, Louis Galambos is a familiar name. He and a team of dedicated researchers have made an important contribution to the field of modern American history by collecting and publishing The Eisenhower Papers. This multivolume work, published by the Johns Hopkins University Press, has made accessible thousands of documents at the Dwight D. Eisenhower Presidential Library in Abilene, Kansas, and other repositories. Galambos surely drew on this valuable research to write his biography of Eisenhower.

Galambos's passion for Eisenhower's life, built while putting together The Eisenhower Papers, is the

Zachary M. Matusheski is a lecturer at The Ohio State University. His book project, Escalating for Peace: Dwight D. Eisenhower and East Asian Crises, 1953-1956, measures the ways East Asian crises shaped Eisenhower's foreign policy reforms best part of the book. Most Eisenhower scholars know that the former president grew up on the literal wrong side of the socioeconomic tracks. Galambos innovates by delving into what that might have meant to Eisenhower during the course of his life. The author reaches back to those early years to explain why Eisenhower believed so strongly in economizing as president. In his chapter on Eisenhower's presidential domestic policy, Galambos concludes, "It may sound quaint or even humorous to you, but my sense is that it was not easy or fun when one of the younger brothers had to wear a pair of second-hand women's shoes to school" (p. 173). Galambos deserves some credit for resurrecting this obscure fact and using Eisenhower's childhood to explain his fear of overspending, even though the author did not cite the source where this anecdote originated.

Students of modern American military history and Eisenhower's life will find the author's coverage of the prewar and World War II periods familiar. Galambos's analysis of Major General Fox Conner's mentorship of Eisenhower is cogently written but does not offer much in the way of new information. The same is true regarding Galambos's analysis of Eisenhower's years spent working with General Douglas MacArthur. The content on World War II that follows is also largely well-known. Galambos's talent in this part of the book is in covering so much information quickly without omitting the important details.

The next section of the book, detailing Eisenhower's domestic policy during his presidency, is of mixed effectiveness. On one hand, Galambos argues convincingly that concerns about the size of the state and government spending drove nearly all of Eisenhower's domestic policy. The president fervently believed that if federal spending was kept low, inno- 
vation would be encouraged and freedom would be more easily secured. On the other hand, some scholars may be disappointed in two key oversights in this part of the book. There is only a brief review of Eisenhower's promotion of civil rights, a leadership challenge that could have strengthened Galambos's main thesis. Moreover, the persecution of homosexuals in the federal government that Eisenhower abetted in Executive Order 10450 is completely absent from the book. Covering these problems related to civil rights and justice would have helped Galambos offer greater insight into Eisenhower's leadership choices.

The next chapter on foreign policy is missing large parts of the challenges Eisenhower faced during his presidency. Galambos makes no mention of the critical choices Eisenhower made in Central America or the Caribbean. The coup Eisenhower authorized in Guatemala is not mentioned, nor is his policy toward Cuba. Eisenhower's legacy cannot be adequately measured without mention of these foreign policy decisions.

The author also falters in Eisenhower's handling of nuclear weapons policy, failing to measure the reforms that the New Look national security policy of- fered. There is no mention of Eisenhower's promotion of sharing peaceful nuclear technology throughout the world under the "Atoms for Peace" program. Eisenhower left important legacies regarding these issues that should have been included in any book detailing his leadership.

Finally, Galambos's handling of Eisenhower's choices on Vietnam is the book's most glaring oversight. Eisenhower refused to de-escalate the U.S. mission in Vietnam repeatedly throughout his presidency, opting to support the anti-Communist mission in Vietnam even when his advisors reminded him of how weak the positions of the French and, later, South Vietnamese president Ngo Dinh Diem were.

All of these omissions in Eisenhower: Becoming the Leader of the Free World undercut the book's effectiveness as both a useful, widely accessible history and a piece of serious scholarship. To draw the most valuable lessons from Eisenhower's life and career, it is necessary to look at his successes and failures. Only then can historians truly measure the former president's influence on the twentieth century and his effectiveness as a leader. 


\section{Major Timothy Heck, USMCR}

Treacherous Passage: Germany's Secret Plot against the United States in Mexico during World War I. By Bill Mills. (Lincoln, NE: Potomac Books, 2017. Pp. 256. \$29.95 cloth and e-book.)

Porfirio Díaz (1830-1915), a former soldier who served as president of Mexico, famously once remarked:"Poor Mexico! So far from God and so close to the United States." Beginning in 1910, Mexico underwent a violent revolution that lasted a decade, during which it was invaded by the United States twice. In the midst of the chaos, German diplomats and secret agents attempted to foment further conflict between Mexico and the United States as part of their strategy to keep America out of Europe during World War I. The Zimmerman Telegram of 1917 remains the best-known German attempt at embroiling Mexico in World War I. Lesser-known intrigues surrounding several ships in western Mexico and American counterintelligence efforts provide the substance for Bill Mills's Treacherous Passage: Germany's Secret Plot against the United States in Mexico during World War I.

Treacherous Passage reads like the spy thriller it is. Plot and counterplot, assisted by an exotic locale and intriguing characters, are related by Mills in engaging prose that keeps the story moving along. Readers seeking to better understand Mexico's role in the First World War, its relationship with the United States, or American or German secret services will all gain something from this work on a relatively minor incident.

Barbara Tuchman's The Zimmerman Telegram (1958) masterfully brought Mexico's role in World War I back to historiographic attention in the late 1950s. Engaging and expansive in scope, The Zimmerman Telegram was written with a "sense of drama and a scholar's obeisance to the evidence." Writers and historians since owe Tuchman a debt when it comes

Timothy Heck is a field artillery officer by training.

${ }^{1}$ Charles Poore, review of The Zimmerman Telegram, by Barbara Tuchman, New York Times, 30 September 1958. to exploring the intricacies of Germany's ever-shifting positions with regard to the United States in World War I. That Tuchman's work is not a referenced material in Treacherous Passage opens Mills up to questions about the thoroughness of his thesis and story.

Mexico's revolution opened the door for American intervention, from the U.S. occupation of Veracruz in 1914 to U.S. Army general John J. Pershing's punitive expedition against Pancho Villa in 1916-17. European powers, too, played a hand in Mexican affairs during this period. Mexico's rich Tampico oil fields provided 75 percent of the British fleet's oil, essential for maintaining the naval blockade on Imperial Germany. Centered around the city of Mazatlán on Mexico's west coast, German businessman and honorary consul Johann Friedrich Unger sought to support German war efforts in a variety of ways. Together with his associate, Gustav Burgmeister, Unger actively engaged in circumventing the American Trading with the Enemy Act of 1917, which imposed a trade embargo on German companies. Employing a variety of subterfuges, Unger was largely successful in importing embargoed supplies.

Central to Treacherous Passage's story, Unger worked to obtain ships capable of service as commerce raiders or auxiliary coalers for German naval forces at work in the Pacific. His primary target was the sunken Mexican Navy ship Morelos. Using numerous front companies, he was able to purchase the ship for refurbishment. Unger's next target was the purchase, refitting, and equipping of the Alexander Agassiz, a former oceanic research vessel owned by the struggling Pacific Coast Trading and Shipping Company. His efforts, and numerous other plots, however, were subverted by Paul B. Altendorf, an American intelligence agent passing himself off as a loyal German. 
The saga of the Alexander Agassiz comprises the bulk of Treacherous Passage. Mills provides a solid background on the ship, its owners, and its fate before it attracted Unger's eyes in the Mazatlán harbor. Its owner, Maude Lochrane, a character worthy of her own biography, was struggling to make ends meet, keep the ship afloat, and stay one step ahead of her creditors. In February 1918, after America's entry into World War I, Unger introduced Cornelius Heintz and Fritz Bauman to each other with the intent of launching "a German commerce raider ... capable of capturing an unsuspecting steamer for use in seizing and sinking additional Allied ships" (p. 82). Heintz was to rebuild the ship while Bauman, a German naval officer, would convince Lochrane of the profits to be made in the South Seas trade. Everything went according to plan until it was thwarted by Altendorf and another American informant: Heintz himself.

Altendorf remains a controversial figure in the history of American intelligence, for he was at once incredibly successful and extraordinarily foolish. His string of successes in Mexico and, later, in the United States at thwarting German machinations is impressive. When the war ended, he was demobilized like thousands of other Americans and departed with a letter of recommendation stating that he was "a man of exceptional talent ... possessed of experience way beyond his years" (p. 179). After a brief stint at the U.S. Bureau of Investigation, Altendorf started writing his memoirs for publication. The result was that he "dishonored his service by revealing secret operations for money" (p. 181). The 1920s brought Altendorf only further discredit, and he disappeared from the pub- lic scene by the conclusion of the decade. For modern readers, accustomed to seeing bylines from former intelligence and covert operatives, the rapid decline of Altendorf's star, which started with his memoirs, is somewhat incongruous with present-day experiences. Nevertheless, at the end, Altendorf was perhaps most aptly described as "an adventurer out of luck" (p. 193).

The work, while engaging, is not without problems. As previously mentioned, the events in Mazatlán are of minor importance to the American and German war efforts. Mills does not adequately place them in the larger context of German efforts to upset American strategy or planning. His omission of Germany's duplicity in prompting America's involvement is the largest oversight. Furthermore, he has included several factual errors about the German secret services in the United States and Mexico during the war, which could have been prevented.

Ultimately, Treacherous Passage, while offering an interesting look at a bizarre and complicated event in the Mexican-American relationship during World War I, retells a story of marginal importance to the overall efforts of any side. The machinations related here were dwarfed in terms of impact and scope by the events of the Zimmerman Telegram or efforts in the United States itself. Readers looking for an expanded picture should read Tuchman's work, while those interested in more cloak-and-dagger tales should read books such as Dwight R. Messimer's The Baltimore Sabotage Cell: German Agents, American Traitors, and the UBoat Deutschland during World War I (2015) or Howard Blum's Dark Invasion: 1915-Germany's Secret War and the Hunt for the First Terrorist Cell in America (2014). 


\section{William E. Kelly, PhD}

Always at War: Organizational Culture in Strategic Air Command, 1946-62. By Melvin G. Deaile. (Annapolis, MD: Naval Institute Press, 2018. Pp. $320 . \$ 34.95$ cloth.)

Always at War: Organizational Culture in Strategic Air Command, 1946-62 tells the story of the U.S. Strategic Air Command (SAC) during the early Cold War period. The author describes how this prominent military organization developed its own culture, defined by unique characteristics that made it noticeably different from other U.S. military organizations at the time.

After the end of the Second World War, the international balance of power changed, and the United States and the Soviet Union became two great powers engaging in a new type of conflict called the Cold War. SAC was first established because of a view that the best way to deter an enemy was to possess a longrange air force that could deliver a powerful weapon, such as a nuclear warhead. This was certainly understandable considering the fact that the Soviet Union had developed a nuclear capability that constituted a significant threat to the United States. SAC had the necessary tools: a bomber that could reach the Soviet Union and a weapon-the atomic bomb-that could be used against an adversary. No other American military organization possessed these important items needed to counter an enemy threat.

SAC's uniqueness was also apparent in other ways. Its headquarters was located in the middle of the United States rather than near Washington, DC, and many of the bases associated with its command were located in various parts of the United States as well as in foreign countries near the Soviet Union. It could attack an enemy from a variety of locations. SAC also differed from other U.S. military commands in leadership makeup and style. Most of its highranking officers were pilots, and many of them had

William E. Kelly is an associate professor of political science at Auburn University, Auburn, AL. served previously as bombing commanders during World War II. General Curtis E. LeMay stood out as a leading Air Force commander of SAC not only because of his professional background but also because of his style of leadership, which seemed to be that of having a constant desire for improvement. For example, LeMay attempted to raise morale in a number of ways, such as by offering spot promotions and more pay and by attempting to improve housing situations for members of his command.

There is no doubt that SAC became a premier American military organization. Yet, both domestic and international changes affected its role as a military unit during the Cold War. This became quite evident during the Vietnam War. What brought an end to SAC's dominance in some military matters was the decline in importance of massive retaliation, which suggested a need for long-range strategic bombers and the atomic bomb to contain Communism, as doctrine. American involvement in Vietnam replaced that doctrine with one of flexible response, which negated the reliance on large intercontinental bombers and instead implied the need to increase conventional forces to effectively counter insurgent movements. The author quotes President John F. Kennedy as saying: "There has got to be a better way than to contain communism with a direct confrontation nuclear bombwise" (p. 219).

The book is organized into seven chapters. Chapter 1 illustrates the beginning of air power in the United States and shows how new attitudes affected its growth, while chapter 2 describes the early wartime experiences of some of the future leaders of SAC. Chapter 3 argues why there was a need for an organization like SAC during the Cold War period. Curtis LeMay is the subject of chapter four, which is 
perhaps the most interesting chapter because of the author's depiction of him. Chapter 5 argues that the Korean War, though a limited war, had an effect on SAC, then a large military organization planning for a larger conflict. The uniqueness of the SAC culture and environment is the subject of chapter 6 , while chapter 7 shows how the introduction and use of new weapons such as missiles affects military organizations.

The author consulted various sources when writing this book, particularly the interviews with former high-ranking officers of SAC that provided interesting anecdotal information. The author also sought out information from the National Archives and Records Administration and the Air Force Historical Research Agency. This book is a work that will appeal to those who have an interest in the history of air power and want to learn more about how organizational characteristics may impact the functioning of a major military organization.

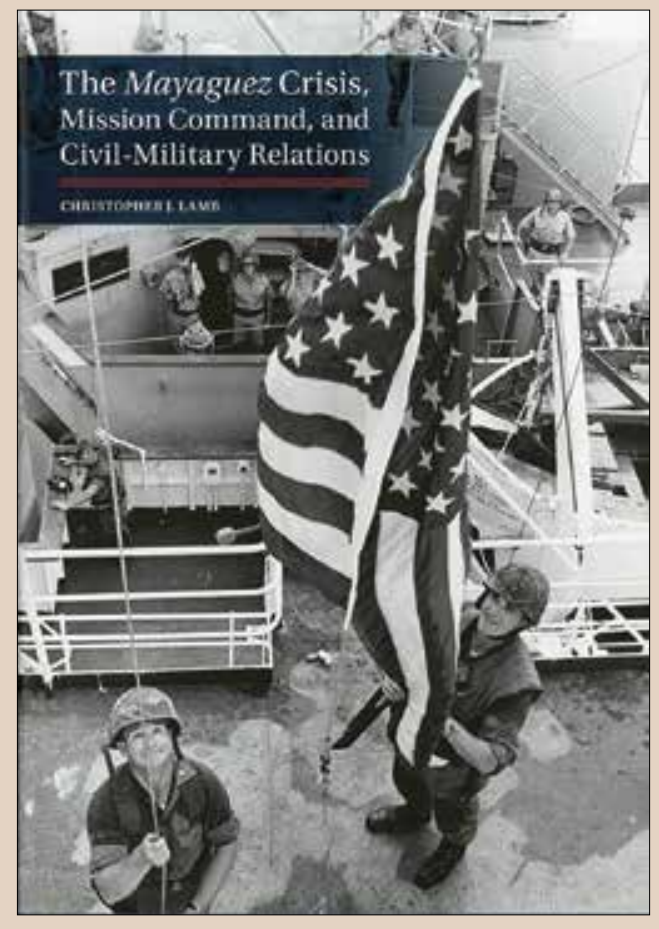

NEW FROM THE JOINT HISTORY OFFICE The Mayaguez Crisis, Mission Command, and Civil-Military Relations

Christopher J. Lamb

cloth $\quad 7$ x $10 \quad$ xxiv + 284 pp.

President Gerald R. Ford's 1975 decision to use force against Cambodia after it seized the SS Mayaguez merchant ship is one of the best documented but least understood crises in U.S. history.

Drawing upon newly declassified material, Christopher Lamb's The Mayaguez Crisis, Mission Command, and Civil-Military Relations dispels popular misconceptions about U.S. motives and behavior during the crisis. He then extracts lessons for such current issues as mission command philosophy, civilmilitary relations, and national security reform. In closing he makes the argument that the incredible sacrifices made by American servicemen during the crisis-including the U.S. Marines who lost their lives or were woundedmight have been avoided but were not in vain.

Free digital version at http://wwww.jcs.mil/About/Joint-Staff-History/ Print version available for purchase in the GPO Bookstore. 


\section{Zayna N. Bizri, PhD}

The Second Line of Defense: American Women and World War I. By Lynn Dumenil. (Chapel Hill: University of North Carolina Press, 2017. Pp. 360. \$39.95 cloth; \$27.95 paperback; \$29.99 e-book.)

Lynn Dumenil's The Second Line of Defense: American Women and World War I is an engaging exploration of the roles women played in World War I. Dumenil argues that women used their wartime service to break down social barriers, though they were ultimately not as successful as many had hoped. Activists used women's wartime service as an argument for equal rights, including suffrage. The author further argues that women's military service and wartime industrial work helped clear the way for them to continue in those trades after the war ended. But while women gained access to new kinds of work and new roles in society, higher political office remained closed to them. For Dumenil, women's patriotic activities in World War I were an early battle in the long-running war for women's full citizenship in the United States.

In this book, Dumenil explores the concept of maternalism and how it was used in wartime activism. Women cast as mothers of the nation or mothers of soldiers were more widely accepted and considered authorities on their various areas of expertise. Dumenil notes that women's wartime events were more social and more optimistic than men's and centered on feminine work-most notably, American Red Crosssupported knitting circles (pp. 95-99).

Dumenil also thoroughly explores the racial implications of women serving their country during the height of the Jim Crow era. African American women faced multiple pressures to fulfill ideals as women as well as African Americans. Dumenil's focus on Afri-

Zayna N. Bizri studies the history of Marine Corps recruiting practices, both visual and textual, targeting women from World War II to today, as well as how those practices both reflected and changed contemporaneous ideas of gender and womanhood. She is currently completing the book project Selling Her the Military, a study of advertising's role in the military's recruitment of women during World War II. She teaches world history at George Mason University, Fairfax, VA. can American women's activism centers on political organizations such as the Universal Negro Improvement Association and African Communities League (UNIA-ACL), the National Association for the Advancement of Colored People (NAACP), and the U.S. Democratic Party. While Dumenil might have explored issues of intersectionality more in her text, she offers a basic primer for readers who are unfamiliar with the history of African American women's political activism (pp. 257-59).

Any history of American society and culture during World War I must address radicalism and women's role in various political parties and progressive movements. Dumenil addresses radical women in a distinct chapter, but the discussion is oddly separate from the rest of the narrative. The events are decontextualized and not folded into her larger timeline. Consequently, women's radicalism seems an anomaly rather than one of many paths women could take at the time (pp. 13-57).

Dumenil references a varied and interesting corpus of sources, including films and promotional materials featuring film stars as well as famed wartime propaganda posters that portrayed sexualized white women as the victims of a brutish and animalistic Germany. Dumenil identifies the sexual threats found in these posters but does not fully engage in the historical discussion centered around the propaganda of World War I (pp. 204-54).

There is certainly room for more conversation regarding the ways propaganda plays into American society and the influence that it had on audiences, in particular women, at that time. Following World War I, propaganda lost what good reputation it had before the war, with many considering it manipulative at best and outright untrue at worst. By the start 
of World War II, U.S. government information organizations avoided using the term propaganda as much as possible. There was an opportunity for Dumenil to explore how propaganda changed during World War I and to describe propaganda's fall from grace, but her focus on women as subjects of propaganda as part of the larger study of women's roles in the United States necessarily prevented her from further exploration of propaganda as a whole.

Dumenil includes several interesting images in her book, though she leaves out a few that are discussed and fails to adequately describe those exclusions. Such poor descriptions create confusion, leaving the reader struggling to understand her larger point. In a section on "Boundary-Crossing Women," Dumenil describes several magazine and newspaper articles that used images to emphasize their points. Those images are not included-yet there are cases of other, redundant images throughout the book. For example, the inclusion of the "Munitions Girl" image described on page 215 would help showcase Dumenil's point, while four images of Mary Pickford, all making the same point, seem unnecessary (pp. 215, 248-51).

Dumenil has written an engaging monograph on women's participation in World War I. She addresses multiple issues, including the role of the "New Woman" ideologies, radicalism, and maternalism. While the author might have addressed African American women's histories more thoroughly, she has nonetheless opened the door for further discussion. She also situated her work adjacent to current studies in wartime propaganda, though without fully engaging with the existing historiography. This book is an important and interesting addition to the libraries of scholars studying American women's military history.

$\cdot \mathbf{1 7 7 5}^{\bullet}$

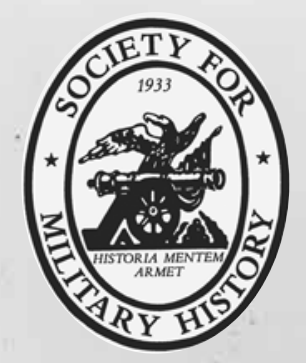

Individual Subscription: $\$ 70$ Institutional Subscription: \$120 Add $\$ 10$ for postage outside the U.S. and Canada Student online access: $\$ 25 /$ year

\section{The Journal of Military History}

\section{A quarterly publication of the Society for Military History}




\section{J. Davis Winkie}

The Veterans Cemeteries of Texas. By Michael Lee Lanning. (College Station: Texas A\&M University Press, 2018. Pp. 188. \$29.95 cloth.)

Prolific popular military historian Michael Lee Lanning's latest book, The Veterans Cemeteries of Texas, aims to be "a complete guide," as the back cover puts it, to Texas's veterans cemeteries. It lives up to that billing, though not in the manner one would expect from an ostensibly scholarly text. In only 178 pages, Lanning, a retired Army lieutenant colonel and decorated Texas veteran, provides an exposition of the state's 10 official burial sites, weaving together historical narratives, photographs, biographies, and regulations to deliver a detailed understanding of the individual cemeteries and their character. To be clear, this book does not attempt anything beyond description-Lanning avoids the literatures of memory and memorialization altogether, and he only briefly mentions national memorialization practices and policies insofar as they affected Texas cemeteries-but a fuller exposition would have been irrelevant to his goal.

The book's organization is simple and supports Lanning's purpose. The author separates it into two parts-one for federally administered cemeteries, the other for state-run-comprising chapters that correspond to the individual cemeteries. The two-part division, however, is unnecessary. Even Lanning recognizes that "other than the signs at their entranceways that identify them as either a [Veterans Affairs] VA or state cemetery, there is no difference" (p. 4). The chapters are all structured identically, varying only in length. Each includes a short narrative of the cemetery's establishment and evolution, a deluge of photographs taken by the author, a small section for

J. Davis Winkie is a historian of race, violence, and memory in the twentieth century United States who primarily writes on war movies and memorials. He is currently project archivist for the Veterans History Project at the Atlanta History Center, GA. "notable persons," and a special section for Medal of Honor recipients.

The narrative portions feature clear, readable prose and provide readers with a good understanding of each cemetery's history. They are where Lanning is at his best, such as when he effectively relates Kerrville National Cemetery's complex transformation from family burial ground to tuberculosis hospital graveyard to official veterans cemetery. Readers may be frustrated, however, by the book's inadequate citations. While Lanning does include an appendix on sources, it only offers vague hints about how he built the individual narratives, citing brochures that "contained information on . . history" and a list of books, some of which surely informed his narratives, though the reader is left with no idea of which books influenced which part of his narrative (p. 171). That is not to say that cluttered academic footnotes are the answer, for they would have distracted readers from Lanning's purpose, but a small number of endnotes would have alleviated this reviewer's concerns.

What definitely distracts from the narratives, though, is the inclusion of too many photographs. While Lanning is a skilled photographer, his words fail to stand out against the 123 color photographs that litter the book's 145 pages preceding the appendices. The photographs universally lack captions; many do not correspond to the text on the page; and virtually none of them serve Lanning's purpose beyond showing the reader-ad nauseam-what the cemetery in question looks like. While the use of some photographs is appropriate given the author's goal, their overuse makes them mere filler in an already-slim book. When the images do correspond to their accompanying text, it is more often than not one of the headstones belongs to a notable person or Medal of Honor recipient. 
The subsections in each chapter devoted to notable and decorated interments advance Lanning's "complete guide" goal through colorful anecdotes that indirectly offer a testament to the purpose of veterans cemeteries as eternal "bivouacs" for a cross section of American society. The author smartly highlights individuals from all walks of life, ranging from Buffalo Soldiers to a Negro Leagues superstar to civilian politicians. However, these sections are not without their distracting idiosyncrasies. The author's wide net for "notable persons" captures a handful of failed actors and musicians, as well as an Army officer killed on 11 September 2001 specifically by "radical Islamic terrorist [sic]" (p. 57). In an "author's note" on page 88, Lanning accuses U.S. Army historian Samuel Lyman Atwood Marshall of having fabricated a quote from his brother in one of his books. Those moments derail the reader's focus and blunt the sections' illustrative power.

An assemblage of diverse appendices rounds out the book. One reprints poet Theodore O'Hara's "The Bivouac of the Dead" in its entirety. Appendices concerning eligibility requirements for burial in a VA cemetery, the cemeteries' addresses, floral and grounds policies, and authorized religious belief emblems for headstones are technically relevant but ultimately unnecessary to the book's purpose-to borrow the author's words, "other information on each cemetery is available by checking cemetery sites on any Internet search engine" (p. 171). Still, they are there, inflating a thin book by more than zo pages.

Measured against its narrow goal of providing "a complete guide to these bivouacs of the dead," The Veterans Cemeteries of Texas cobbles together enough information to achieve this purpose, and Lanning's straightforward, accessible prose helps. But this book's haphazard approach is unbefitting of a book published by a university press. Lanning's work is better regarded as excellent travel literature-the category to which Amazon has relegated it-than an attempt to add to the existing academic literature on cemeteries and memorialization. That reality notwithstanding, this book is recommended as a quick reference for scholars dealing tangentially with the cemeteries in question or as a reference for Texas veterans conducting research for their end-of-life plans.

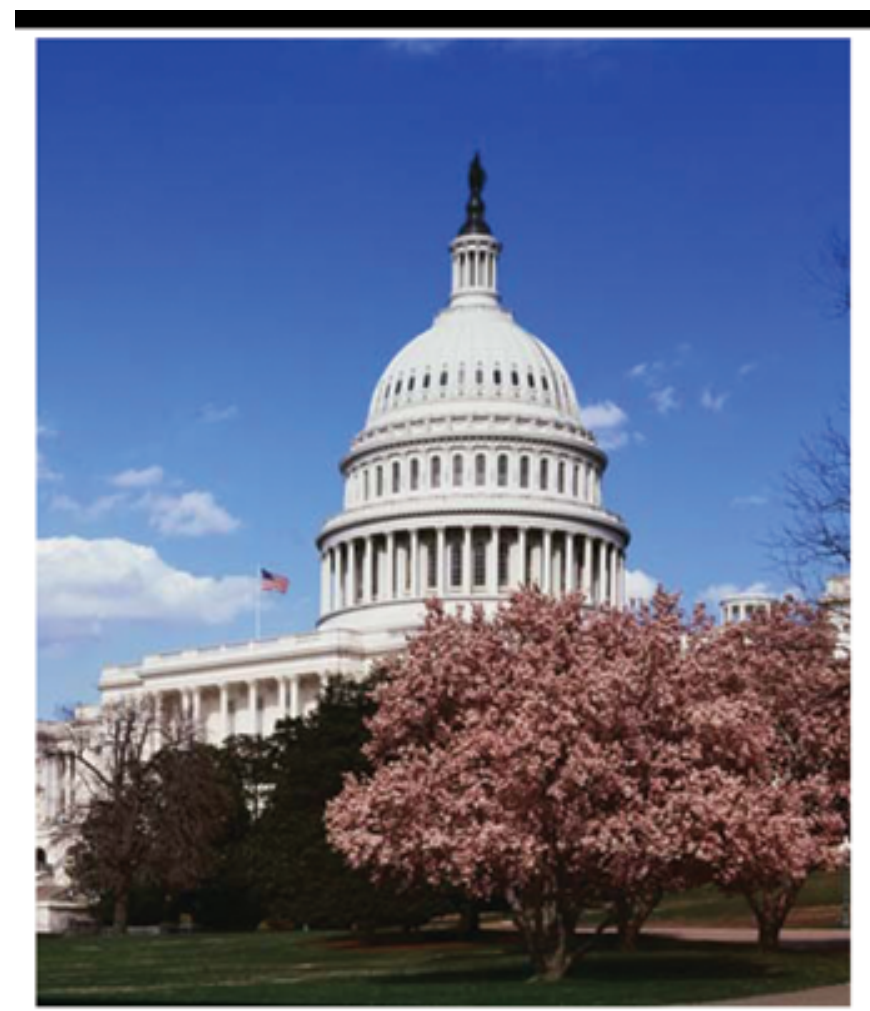

\section{Society for History in the Federal Government (SHFG) www.shfg.org}

SHFG brings together government professionals, academics, consultants, students, and citizens interested in understanding federal history work and the historical development of the federal government. Join us for our annual conference, honorary lectures, workshops, and gatherings.

Members receive our newsletter, The Federalist, the journal Federal History, our eBulletin, and news of Society events.

Join SHFG at shfg.wildapricot.org/join-us 


\section{Ethan Lett}

The U.S. Army Campaigns of World War I: Into the Fight, April-June 1918. By Mark E. Grotelueschen. (Washington, DC: Center of Military History, U. S. Army, 2018. Pp. 79. Free paperback.)

The First World War revolutionized the way in which modern conflicts would be fought. Countries devoted their industrial might to mass-producing new weapons of war, resulting in bloodshed never before witnessed in human history. Gone were the days of traditional European warfare in which opposing armies faced off across battlefields, standing shoulder to shoulder and exchanging volleys of fire into enemy ranks. Technological innovations in firearms and artillery necessitated the adoption of new combat strategies that transformed modern armies into swift, mechanized fighting forces. The belligerents of Europe spent three years developing these tactics only to find themselves in an unbreakable stalemate. When U.S. soldiers stepped onto the killing fields of France in 1918, they too were introduced to the gory lessons of warfare in the modern age.

Written by Mark E. Grotelueschen, Into the Fight, April-June 1918 is the fourth installment in the commemorative series The U.S. Army Campaigns of World War I, which details the involvement of the American Expeditionary Forces (AEF) in the First World War. Into the Fight offers insight into the logistical issues that delayed American mobilization as well as the trials and tribulations faced by U.S. soldiers during their first encounters with German forces in 1918. Covering the AEF's baptism by fire between April and June, this pamphlet covers six major operations in which American soldiers were introduced to the horrors of modern combat and proved to be a formidable fighting force that helped turn the tide of the war.

In the months preceding the first American

Ethan Lett served as an intern for the Archives Branch of Marine Corps History Division in 2019. shots fired on the western front, Allied commanders grappled with the issue of organizing U.S. troops into fighting units and deploying them to the front lines. Grotelueschen acknowledges the efforts of General John J. Pershing, commander of the AEF, to ensure that U.S. soldiers were organized into their own divisions and commanded by American officers. The author also illustrates the reality of the Americans' inadequate training and supply at the beginning of 1918 .

While this pamphlet is not a comprehensive analysis of many facets of the American experience in the First World War, Grotelueschen offers key insights into several major operations of 1918, including Cantigny, Château-Thierry, the Montdidier-Noyon defensive, Lucy-le-Bocage, and Vaux. Special attention is also given to the U.S. Marines who participated in the Battle of Belleau Wood. Explanations of each battle are carefully detailed as Grotelueschen includes perspectives from both the officers in command and the soldiers who experienced combat firsthand. Details of these engagements are complemented by maps illustrating troop movements, terrain, and frontline positions on both sides of the battlefield.

Into the Fight is an engaging piece of military history, a perfect supplemental reading assignment for an American or military history course, and an excellent initial step for those conducting research on the United States' role in World War I. Grotelueschen provides attention to detail without adversely affecting comprehension, making this commemorative pamphlet an appropriate collection of literature for any scholar or student of American military history.

$\cdot 1775^{\bullet}$ 


\section{MARINE CORPS HISTORY DIVISION'S New Releases}

NEW IN THE SERIES
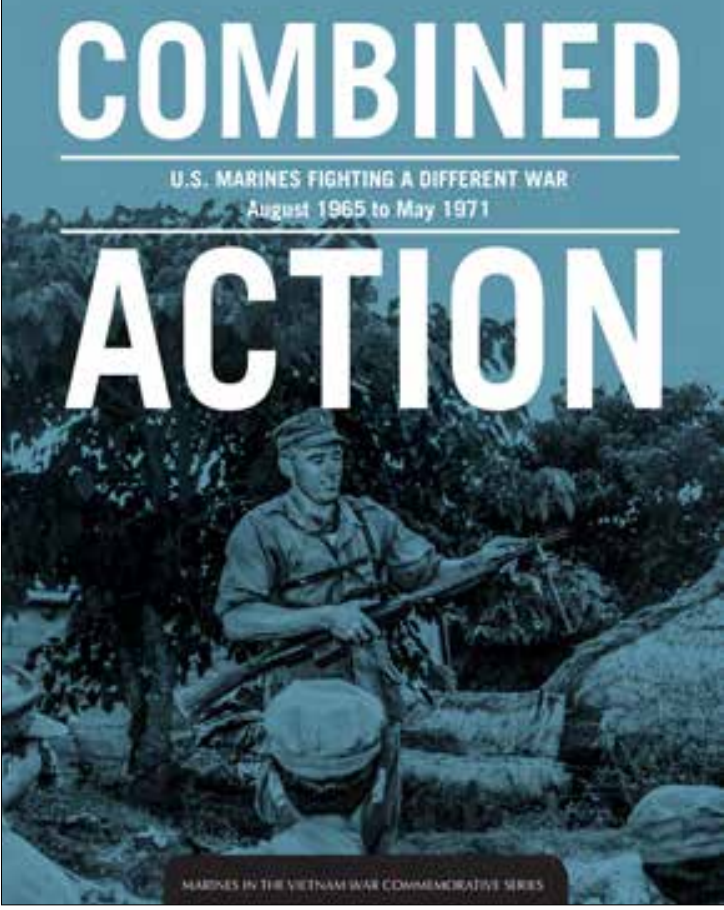

COMING SOON

\section{HEROIC DEEDS \\ HEROIC MEN}

The U.S. Marine Corps and dte Final Pbase of the Met - Irgotn y Campaign 1-1) Noeribe tritis

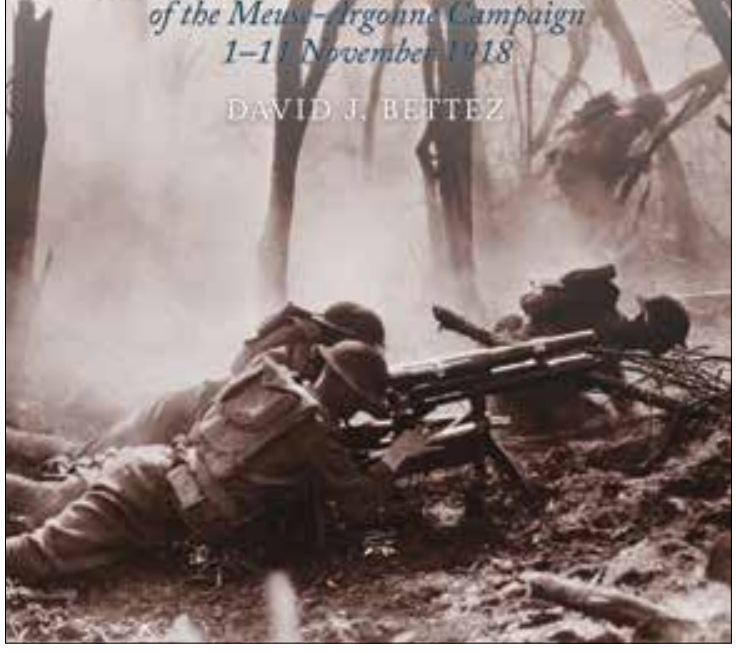

MORE IN THE

Marines in the Vietnam War

COMMEMORATIVE SERIES
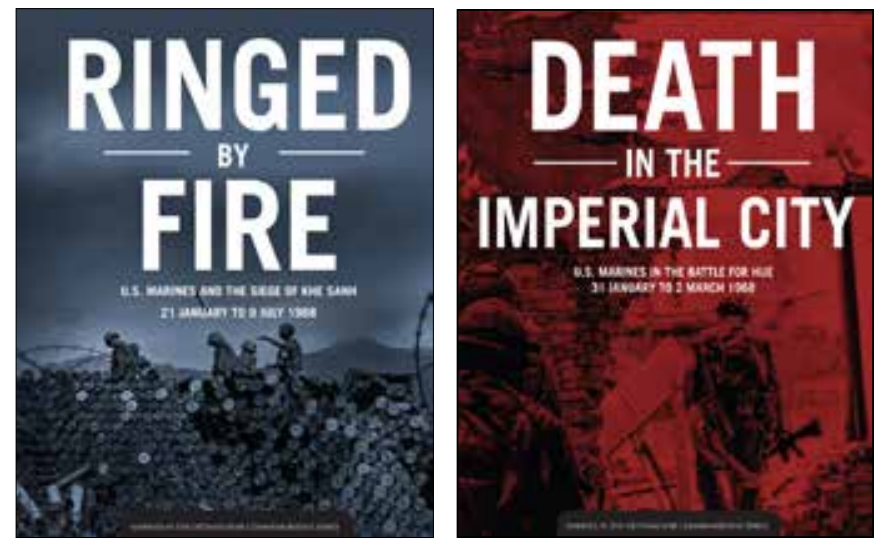

Email mcu_press@usmcu.edu for a print or digital copy.

MORE IN THE

U.S. Marines in World War I Centennial COMMEMORATIVE SERIES
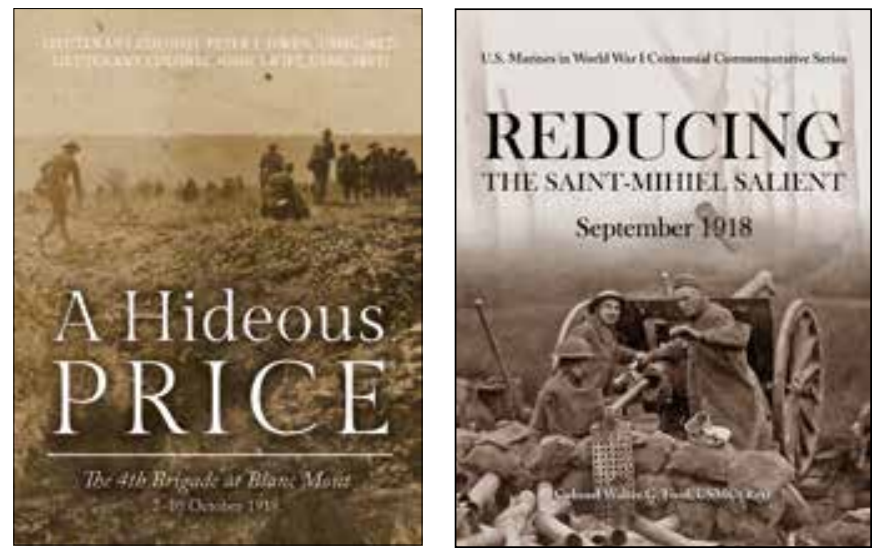

Email mcu_press@usmcu.edu for a print or digital copy. 


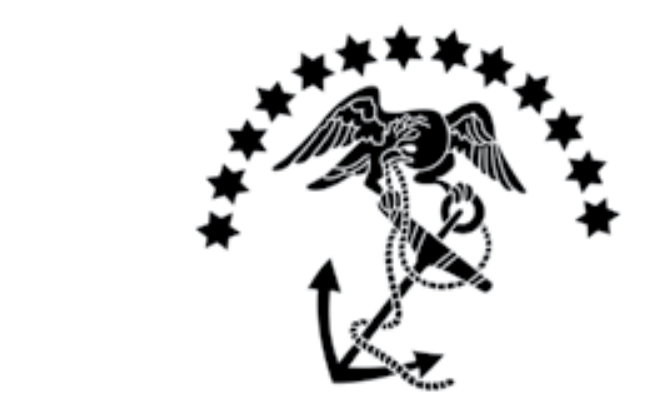

\section{Marine Corps History}

is published as a History Division imprint by MCU Press. Digital issues of Marine Corps History can be found at www.usmcu.edu/mcupress. Email mcu_press@usmcu.edu for a print subscription. 